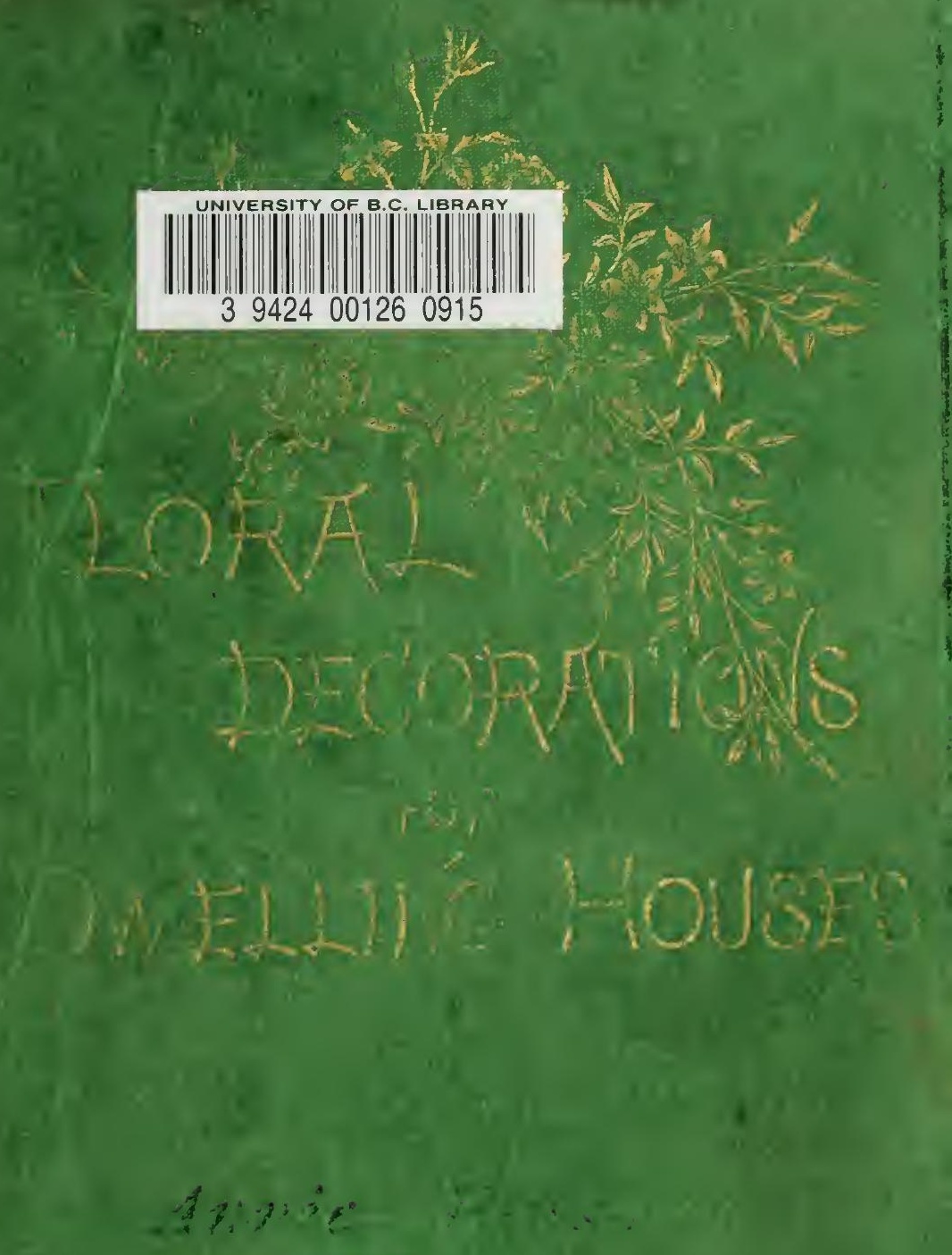

\title{
STCRAGE I'IEN
}

PKCCESSING-CNE

Lp 1-F $19 \mathrm{C}$ U.B.C. LIBRARY 


\section{TIF LIBRARY}

THL I' YIVERSIIY OF BRITISII COLLMBIA

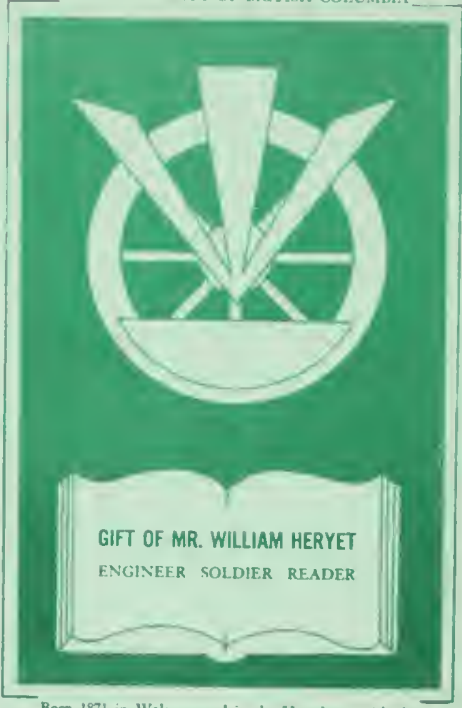

Born 1871 in Wales, serred in the Himalayas with the British Transport Corps and in the Boxer Rebellion, helped construce the C.P.R, fought with the Cunadiaa Eapeditionary Force 1914-17, a resident of Vancosver for forty yean, still a reader at 9 , donated his collection of 4,000 books in 1\%5. 




\section{FLORAL DECORATIONS}

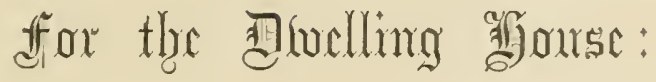

A PRACTICAL GUIDE

TO TH B

HOME ARRANGEMENT OF PLANTS AND FLOWERS.

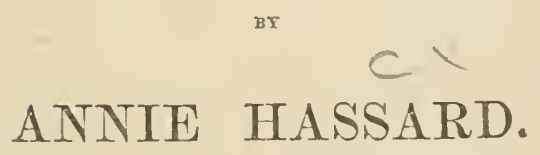

ПITI NTMEROUS ILLUSTRATION゙S.

LONDON :

M $\triangle \mathrm{C}$ M I L L $\triangle \mathrm{N} \& \mathrm{CO}$.

1875 . 


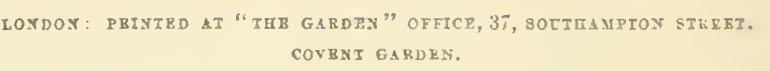




\section{PREFACE.}

The nse of Floral Decorations in houses has become quite general in this country and this fact has induced me to write this little work, in the hope that it may prove a nseful guide to those who, like myself, are fond of deroting a few moments now and then to the arrangement of cut flowers. Whether these flowers be choice, or only wild varieties, they will impart to the table on which they are placed an air of refinement that cannot otherwise be obtained; and the trouble and time spent in arranging them will be repaid tenfold by the pleasing effect produced. I must take this opportunity of thanking Mr. W. Robinson, Editor of "The Garden," to whom I am indebted for many of the accompanying engravings, which serve so well to illustrate the various styles of floral embellishment of which I have given descriptions in these pages.

$$
\text { A. H. }
$$

Upper Norwood, 1875. 
Digitized by the Internet Archive in 2010 with funding from University of British Columbia Library 


\section{CONTENTS.}

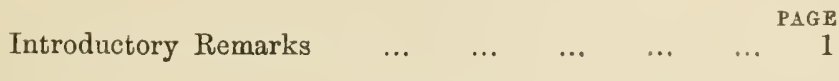

CHAPTER I.

The Artificial Lighting of the Dining-room-How to place Plants through the Dinner-table $\quad \ldots \quad \ldots \quad \ldots$

CHAPTER II.

Forms of Stands-Materials for keeping Flowers fresh

CHAPTER III.

Preparing Flowers - Wiring Flowers - Gumming

Flowers-Keeping Propared Flowers fresh $\ldots .21$

CHAPTER IV.

Arches-Decorations without Stands $\quad \ldots \quad$... $\quad \ldots \quad 29$

CHAPTER V.

Plants through the Table-Groups of March Stands

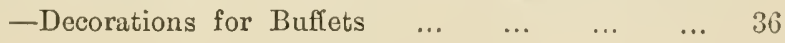

CHAPTER VI.

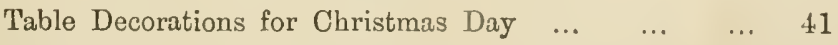

CHAPTER VII.

Arrangement of Fruit for Dessert $\quad \ldots \quad$... $\quad \ldots \quad 46$

CHAPTER VIII.

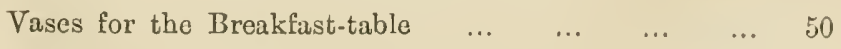

CHAPTER IX.

Vases for the Drawing-room $\quad .$.
CHAPTER $\mathrm{X}$.

Mantel-piece Decoration-Screens for the Fire-place

$\begin{array}{lllllll}\text { Wreaths and Garlands... } & \ldots & \ldots & \ldots & \ldots & 60\end{array}$ 
CHAPTER XI.

Baskets of Flowers-A Vase of Roses-To Arrange

Violets Effectirely-Orchids for Vases $\ldots . \quad \ldots \quad 67$

CHAPTER XII.

Hand Bouquet-Sprays for the Hair

CHAPTER XIII.

Button-hole Bouquets and Coat Flowers

CHAPTER XIV.

Floral Wreaths and, Crosses

CHAPTER XV.

Arrangements of Flowers for each Month $\quad \ldots \quad \ldots \quad \quad \ldots 4$

CHAPTER XVI.

Flowers in Season $\begin{array}{lllllllll} & \ldots & \ldots & \ldots & \ldots & \ldots & \ldots & 105\end{array}$

CHAPTER XVII.

Pot Plants in Rooms

$\begin{array}{ll}\cdots & \ldots\end{array}$

CHAPTER XVIII.

Window Gardening - Hanging Baskets-Fern Cases

$\begin{array}{llllllll}\text { - Stands of Plants } & \ldots & \ldots & \ldots & \ldots & \ldots & 115\end{array}$

CHAP'ER XIX.

Plant Stands for Halls

CHAPTER XX.

The Grouping of Plants in Rooms

CHAPTER XXI.

The Gladwin and Arbutus for Decorative Purposes ... 135

CHAPTER XXII.

Leaf-printing from Nature-How to Skeletonise $\begin{array}{llllllllll}\text { Leares } & \ldots & \ldots & \ldots & \ldots & \ldots & \ldots & \ldots & 140\end{array}$

CHAPTER XTIII.

Dried Flowers, Ferns, and Wild Grasses

CHAPTER XXIV.

Christmas Decorations

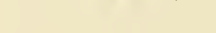




\section{ILLUSTRATIONS.}

Table with gaslight over centre PAGI

$\begin{array}{llllllll}\text { Pot plant through table } & \ldots & \ldots & \ldots & \ldots & \ldots & 10\end{array}$

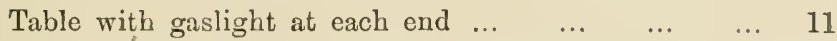

Plant through table arranged with Ferns, \&c... ... 12

$\begin{array}{lllllllll}\text { Oreodoxa regia } & \ldots & \ldots & \ldots & \ldots & \ldots & \ldots & 13\end{array}$

$\begin{array}{llllllll}\text { Dæmonorops accideus } & \ldots & \ldots & \ldots & \ldots & \ldots & 14\end{array}$

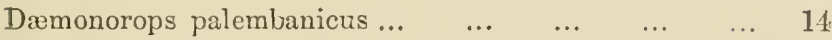

March stand furnished with moveable top vase $\quad \ldots \quad 17$

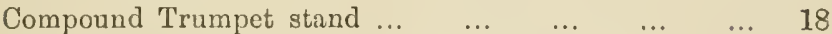

Tray for placing round the bases of plants $\quad \ldots \quad \ldots \quad 19$

$\begin{array}{llllllllll}\text { Bouvardia } & \ldots & \ldots & \ldots & \ldots & \ldots & \ldots & \ldots & 23\end{array}$

$\begin{array}{lllllllll}\text { Camellia } & \ldots & \ldots & \ldots & \ldots & \ldots & \ldots & \ldots & 25\end{array}$

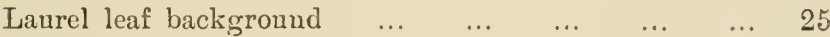

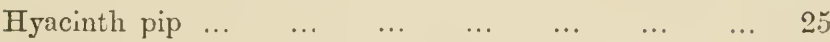

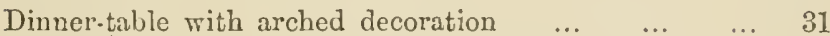

Central ormament for the Dinner-table $\ldots \quad \ldots \quad \ldots \quad \ldots \quad 33$

$\begin{array}{lllllll}\text { Prize dinner-table decoration } & \ldots & \ldots & \ldots & \ldots & 36\end{array}$

$\begin{array}{llllll}\text { Centre ornament for dinner-table } & \ldots & \ldots & \ldots & 38\end{array}$

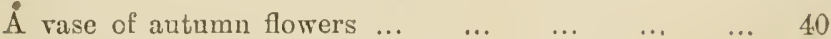

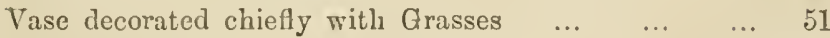

Vase ornamented chiefly with Ferns $\quad \ldots \quad \ldots \quad \ldots \quad$... 53

Trumpet-shaped glass vase, with flowers and trailing

Fern, surrounded by Water Lilies $\ldots \quad \ldots \quad \ldots \quad \ldots \quad 55$

Vase with a few Orchid flowers and Ferns $\ldots . \quad \ldots \quad 56$

$\begin{array}{llllllll}\text { Small vase of flowers } & \ldots & \ldots & \ldots & \ldots & \ldots & 56\end{array}$

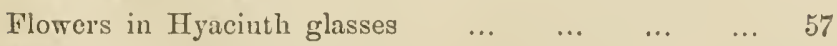

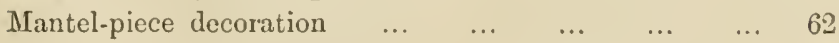

$\begin{array}{llllllll}\text { Iry screen for fire-place } & \ldots & \ldots & \ldots & \ldots & \ldots & 63\end{array}$ 


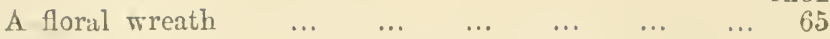

Basket of Maréchal Niel Roses with foliage $\ldots \quad \ldots \quad 69$

$\begin{array}{lllllllll}\text { Spray of flowers } & \ldots & \ldots & \ldots & \ldots & \ldots & \ldots & 76\end{array}$

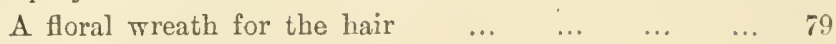

$\begin{array}{llllllll}\text { Button-hole bouquet } \ldots & \ldots & \ldots & \ldots & \ldots & \ldots & 81\end{array}$

$\begin{array}{llllll}\text { A button-hole bouquet for March } & \ldots & \ldots & \ldots & 83\end{array}$

A coat flower (Dendrobium and Maiden-hair) ... $\quad \ldots \quad 85$

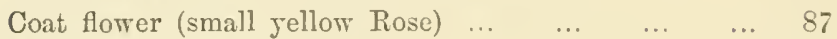

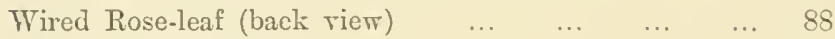

$\begin{array}{llllllll}\text { Ornamental pot corer } & \ldots & \ldots & \ldots & \ldots & \ldots & 110\end{array}$

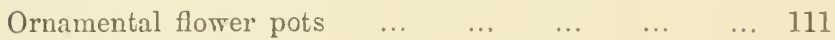

$\begin{array}{lllllllll}\text { Gesnera refulgens } & \ldots & \ldots & \ldots & \ldots & \ldots & \ldots & 112\end{array}$

$\begin{array}{lllllllll}\text { Plant bracket } \ldots & \ldots & \ldots & \ldots & \ldots & \ldots & \ldots & 113\end{array}$

Open bay window garden $\ldots \begin{array}{lllllll} & \ldots & \ldots & \ldots & \ldots & \ldots & 116\end{array}$

$\begin{array}{lllllllll}\text { Blue Conrolrulus } & \ldots & \ldots & \ldots & \ldots & \ldots & \ldots & 116\end{array}$

$\begin{array}{lllllll}\text { Suspended window basket } \ldots & \ldots & \ldots & \ldots & \ldots & 117\end{array}$

A havging basket at South Kensington... $\quad \ldots \quad \ldots \quad 118$

A perforated rase for spring flowers $\quad \ldots \quad$... $\quad \ldots \quad 120$

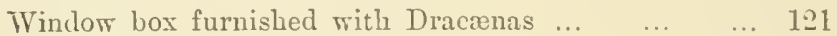

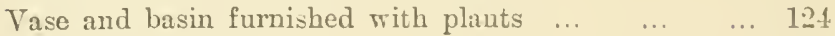

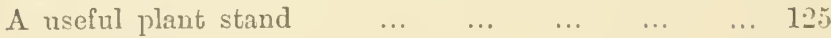

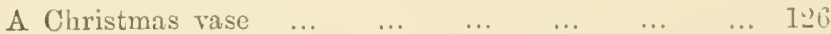

Seed-pods of the Gladwin (Iris fotidissima) $\ldots \quad \ldots \quad \ldots 137$

Bouquet of Grasses and hardy flowers ... $\quad \ldots \quad \ldots \quad$... 152

Iry, Yow, Holly leares and berries ... ... ... 160

Yew, Iry, Aucuba, Holly leares and berries $\ldots . \quad \ldots \quad 160$

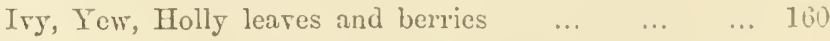




\section{INTRODUCTORY REMARKS.}
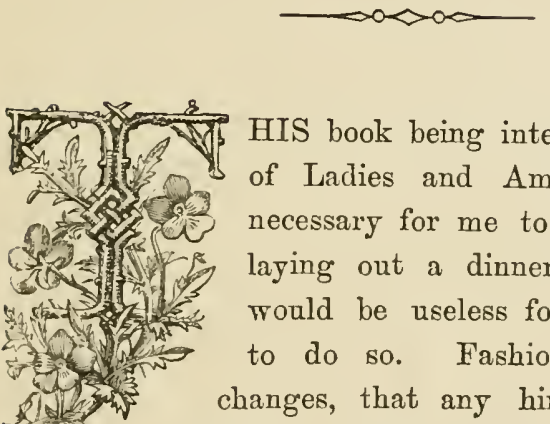

HIS book being intended for the use of Ladies and Amateurs, it is not necessary for me to furnish rules for laying out a dinner-table; indeed, it would be useless for me to attempt to do so. Fasbion so continually changes, that any hints I might give on the subject would, in a few months' time, be valueless. There are, however, some little points relative to stands for fruit, the colour of glasses, and matters of a kindred nature, that help very much to set off the flowers and fruit employed in the decoration of a table, by carrying out the line. of colour and in other ways enhancing the general effect, -and a few words on these subjects will not be out of place here.

As a rule, dishes for fruit accompany all bandsome dessert services; but, if the table be a large one, these are not always sufficient. Under these circumstances glass baskets, for such fruits as Grapes or Peaches, look well interspersed amongst them; then again, there are many pretty stands in white Parian-figures 
supporting baskets or dishes on their heads-pierced and lined with erimson glass which shows out well through the creamy-white of the exterior substance. In summer nothing has a cooler or more pleasing effect than that produced by the exclusive nse. of glass fruit dishes. The stands to be placed at the head and foot of the table, no matter of what material they are composed, should always be higher than the side dishes; for, should the receptacles for the fruit be of a uniform height, a good result will never be obtained.

The next matter I shall turn to are coloured wineglasses. Nothing carries out the line of colour, or tends to gire a pretty effect to a table, more than coloured glasses, provided the right shades are selected; for much depends on this. If they are to be crimson or green, delicate shades should be chosen-just a tint of colour sufficient to give a clear shade will suffice. Many tables have their appearance spoiled by the introduction of massive dark green hock-glasses, which, in place of contributing to the general effect, tend to make the whole surface of the table look heary and loaded. Very small circular salt stands, one of white and one of the same shade of green as the hock-glasses, placed before each guest, look well, and carry out the colour. The white cellars should contain red, and the green ordinary, table salt. Two small spoons should be crossed in front of each pair of salt cellars.

Of late seasons a new style of finger-glass has beeu introduced with a happy result, which, I have no doubt, will quite supersede the old or ordinary form in time. The advantage of the new glass orer the old is that it combines the usefulness of a specimen-glass with that 
of a finger-glass. In form it is that of a tiny trumpet rising out of a tazza; the trumpet acts as a specimenglass to hold a button-hole bouquet or spray of flowers and the tazza forms the finger-glass, florally embellished as I shall describe in another chapter. Where a large table is to be decorated, these glasses are a great advantage, as they lend much aid to the floral display, and remain on the table during dinner, where they are placed (one before each guest) at the same time as the other flower vases. Last season there was also a new specimen-glass for button-hole bouquets introduced. which combined both a specimen-glass and napkin-ring; the part which formed the napkin-ring and stand was of silver, resting in a silver support, and rising from above the ring was the glass. The only objection to these stands are they do away with the folding of the dinner napkin, which, if prettily done, sets off a table to much advantage.

In the matter of "menu" cards there are such varieties in form, material, \&c., that it would be impossible for me to enumerate half those employed: some are mado of china, which can be washed and used over and ove $\mathrm{L}^{\text {. }}$ again; others are embellished with small artistic French pictures; but their selection I leare to the reader's taste, with this advice-do not have them too "prononcés."

Some have broken ice placed on the table; and, agrain, others have it handed round. This is quite a matter of taste; but, in summer, I prefer to hare it placed on the table. I think that when seen amongst the dishes of fruit, its cool and refreshing appearance, and the glitter of its broken irregular edges, are very charming. When handed round, it matters little, so long 
as the receptacle be of glass, what the shape is; but, if it be on the table, the form of the dishes should be as elegant as possible. These can be had at various prices, according to what the purchaser may please to give. In selecting ice-stands, care should be taken that they have plenty of room in the under tray to hold the waste water from the ice as it melts, as the water is liable to overflow if this part be small. The selection of the table-cloth is another point which should receive as much attention as any other, for on it depends, to a great extent, the effect produced by the tasteful arrangements of flowers and fruit. The finer the damask, the better the floral arrangement will appear. Where handsome vases and flowers are employed, the damask of the cloth should have a rich sheen, like that of satin. Beautiful designs are now woven in damask of groups and bouquets of Fern fronds, with wreaths of the same, and Iry round the border, which are quite in keeping with the floral display arranged in the vases.

As I have made many remarks on the selcction of glass, vases, \&e., it may not be ont of place to give a few hints as to the best method of cleaning them. To ensure the preservation of the brightness which always accompanies newly purchased erystal, glass should never be washed in anything but cold water; no soap or any material of that deseription should be rsed, but simply cold water and a flannel cloth, and care should also be taken that the ressel in which the water is placed is perfectly clean and free from grease. A good rule is to kecp a ressel solely for the purpose of washing rases, specimenglasses, \&c., as otherwise it is impossible for them to retain their polish and brilliancy; and separate cloths 
should also be kept for the purpose of drying them. Glass, after being washed and dried, should be finished off with a fine and perfectly dry wash-leather, as no other material gives such a polish. I have several glass vases of different shapes-some to hold water only, others sand-which I bave used at exhibitions and on our own dinner-table for three years or so. At the present time they are as bright and new-looking as when I first had them from the manufaeturer, and they have always been cleaned in the manner above deseribed. If a stand is to be cleaned, the tazzas of which have been filled with sand, and the sand has beeome hard and eaked (which sometimes happens if it has been many days in use), it should never be broken away from the glass in dry eakes, as is often done, as this scores the glass. The tazza or part so filled should be separated from the rest of the stand, and submerged in cold water until the sand beeomes quite soft, when it can easily be removed from the glass. Unless the vessel kept for washing vases be of delf, those parts which hold sand should not be eleansed in it, as the least partiele of sand on the trumpet, or other portions, whilst they are being polished, is liable to score it. In the arrangement of flower's in a vase where wires have to be introduced, the latter are liable, where they rest against the glass, to rust it-no cold water will remove this; some use salt for the purpose, but it oftentimes scores the glass. The best possible remedy for this is spirits of salts, but it must be used earefully, and not be allowed to touch the hands, especially if there happen to be any eut or abrasion of the skin; this ean, however, be easily avoided, and nothing removes the stain of rust so effectually from 
glass or china. Spirits of salts can be used orer and over again, as it is only needful to keep the bottle corked tight, and place it away carefully till required again for nse; it will remain fresh for a long time, but it must not be allowed to evaporate. It can be obtained at any chemist's at a trifling cost. Should the iron-rust have obtained a firm hold on the glass, the part so discoloured may reqnire to be rubbed hard; if this be the case, a little flannel should be bound round the end of a small piece of stick, the portion so corered dipped in the spirits of salts till well soaked, and the discoloured portion of the vase rubbed with it. By adopting this method of use, the spirits need never come in contact with the hands.

It will be found a good plan where there are many rases and stands of different forms, not in daily use, to keep them in a press or on a shelf separate from all other glass, as portions, such as carred branches, \&c., are very apt to get broken, and it is often difficult to match them, the slightest difference being easily detected when the stand is put together. Besides, it often takes some little time to get the part required matched at all; and it often happens, curiously enough, that the broken stand is the one whose services are required at that particular period. I keep all my stands for flowers and fruit, glass baskets, fe., which are not used, except when a handsome floral display is required, in a very large wooden press with five shelves, the press being built against the wall, and cach shelf packed with the stands, ifce, taken to picces; orer each shelf is spread a piece of light muslin, or sheets of tissue paper, which prevent any dust which might come in through the 
cracks lodging on the glass; thus whenever I require any particular vase it is there, clean and ready, requiring only to be screwed together. No glass stand should ever be put away dirty. The time to clean it is not when it is required for use; and stains allowed to eat into the glass will be found very difficult to remove.

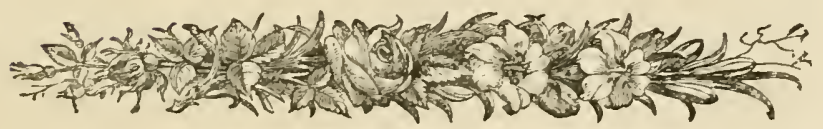




\section{CHAPTER I.}

THE ARTIFICIAL LIGHTING OF THE DINING ROOM-HOW TO PLACE PLANTS THROUGH THE DINNER TABLE.

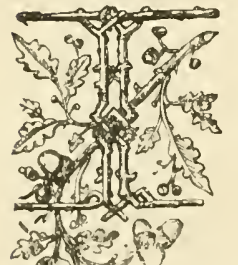

$\mathrm{N}$ selecting stands for the decoration of the dinner-table rnuch will necossarily depend on the manner in which the room is to be illuminated by means of artificial light. Generally speaking, there are but three ways of Sis lighting rooms with gas or wax lights, af viz., lights placed on the table, bracket or wall lights, and the chandelier or gasalier. The style of stand or stands selected for the table wholly depends upon which of the above-named modes of lighting is adopted. For instance, if the room is to be lighted by two gas lights or chandeliers, one at each end of the table, a March stand should be chosen; but if illuminated by a gasalier placed orer the centre of the table, the selection of such a stand would be a mistake, for, the light being abore the stand, though the flowers arranged in the top tazza would be well shown up, those in the lower one would be put into the shade; the top tazza would eatch all the illuminating rays, and keep them off the lower one as effectually as if a 
screen had been placed over it. By such an arrangement as that shown in the accompanying illustration, each tier has its proper share of light. Where the gasalier is placed over the table, the best form to use is a high single slender trumpet, or some such shape, so that when the light happens to fall on it, it will not throw any shadow on the arrangement which may be placed round the base of the

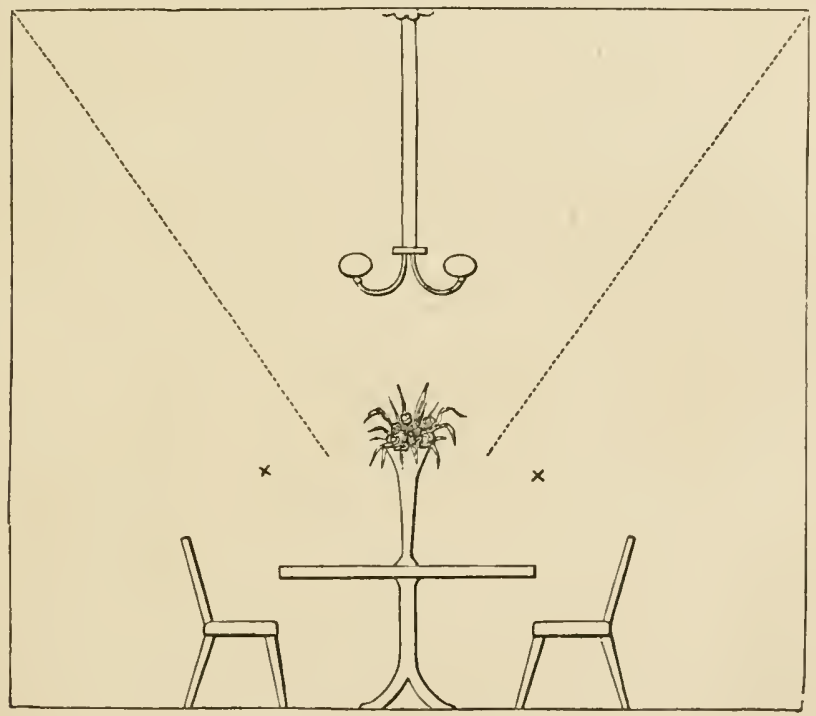

Table with gaslight over centre.

vase. When the light is placed over the centre, flat arrangements can be used with advantage, though, for my own part, where possible, I give preference to something high in the centre. Undoubtedly the best stand for a room thus lighted is the trumpet, or some modification of it-such a stand, in short, as that represented by the accompanying illustration. When about to purchase new 
stands, these remarks should be borne in mind, and also when arranging pot plants on the dinner-table; for the mode of lighting affects them quite as much as the stands. If the lighting is not taken into consideration, large Fern fronds and similar foliage would throw heary shadows on the table-cloth, which would spoil the look of any arrangement in their vicinity.

\section{Plants Plaeed through Dinner-tables.}

Many will doubtless be ready to exclaim, "Who would cut holes in one's dinner-table or table-cloth for such a purpose?" Well, allow me to explain how this can be effected without damaging either the table or cloth. With the exception of those who have seen suitable plants put

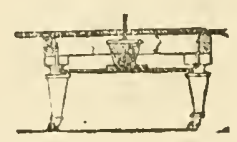

Pot plant through table.

through a table, no one can have an idea of the elegant effect which they produce when arranged in that way. Imagine the striking effect which young Tree Ferns or Palms have in such positions; their elerated fronds shading from the blaze and glare of light the smaller arrangements of flowers and fruits laid here and there on the snowy damask below them, a result which cannot be prodnced unless the plants are put through the table. This may be done in several ways. Dinner-tables are generally of two kinds-the one the telescope, into which may be put as many or as few spare leares as may be desirable; the other that with a large centre and spare ends, which may 
be added at pleasure. There are two ways of putting the plants through these tables. Now-a-days dinner-tables are never, I need hardly say, uncovered, therefore it is of no consequence of what material the top of the table is made, provided one leaf, reserved for a plant in the centre, or two if for a plant at either end, be made of common

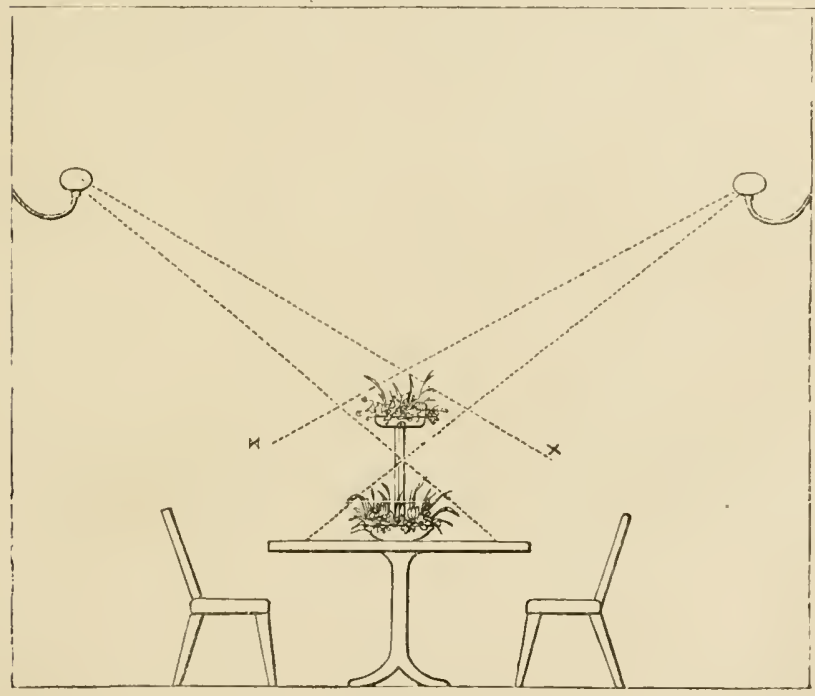

Table with gaslight at each end.

deal, either the same size as the mahogany one for which it is substituted, or only a foot or 18 inches wide, if the table is required to be made shorter. This spare leaf should be cut in two, and a half-circular piece cut out of each piece, which, when re-placed in the table, will leave a circular hole in the centre. Before this deal leaf is lifted into the space from which the mahogany one has been 
removed, a wooden box, or anything that will form a stand for the plant, should be put into proper position; the plant should then be placed on it and carefully raised to a proper height, always keeping the surface of the pots just below the level of the table. Each half of the spare leaf may then be fitted into its place, when the stem of the plant will occupy the centre of the circular hole cut for it. If a plant is to be placed at each end of the table, the best way of supporting them is to have a long plank

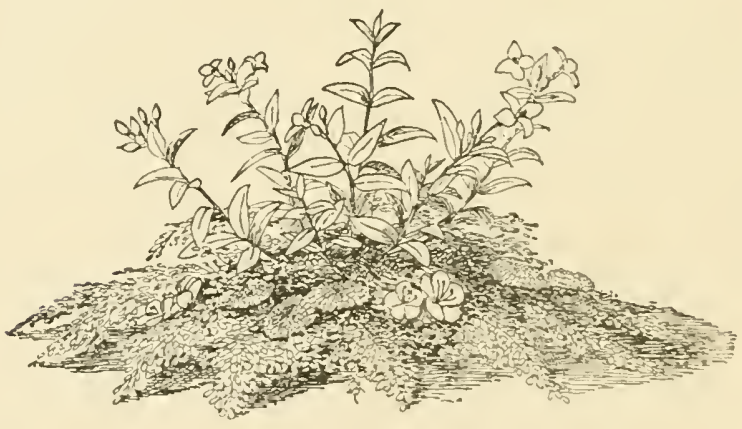

Plant through tablo arranged with Ferns, sc.

underneath. Should Ferns be used, the holes cut out of the spare leaves must be of the same size as the top of the pots, as, in the case of such plants, the pots must be flush with the table. The other plan of arranging plants in this way is to have a small piece of brass or iron that may be drawn across and fastened when the table is within an inch or an inch-and-a-half of closing, which will prerent its either closing or opening. This form is suitable only for Palms, and similar plants. It is in this way the table with extra ends must be managed, and about which there 
is no difficulty; for I constantly practise it. Let us now turn to the covering of the table. The way the tablecloths (for it takes two to each table when so decorated)

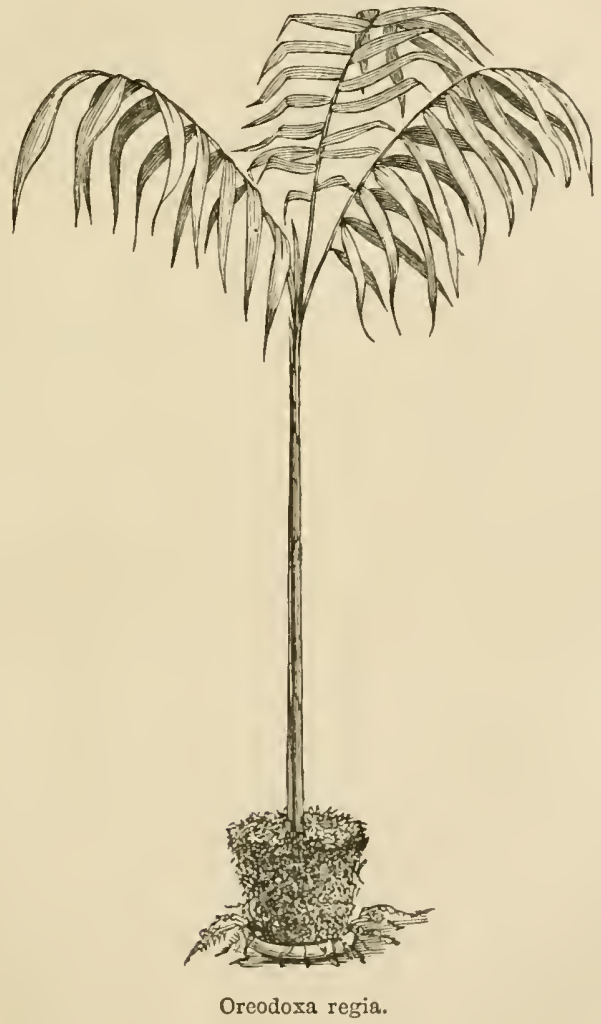

are arranged, is as follows:-The cloths are opened and spread along each side of the table, so as to meet in the centre or lap orer each other about an inch. They should be kept as flat round the base of the plants as possible, and 
the cloths should be pinned together so as to prerent them from being open. A clean flat-iron should next be obtained with which the folds should be neatly pressed, so as to obliterate any appearance of a join. If half the width of the cloth is not found enough to allow it to droop gracefully at each side allow more; but always keep the middle fold flatly pressed, a trouble which will be well repaid by the effect produced. My tables both at South Kensington

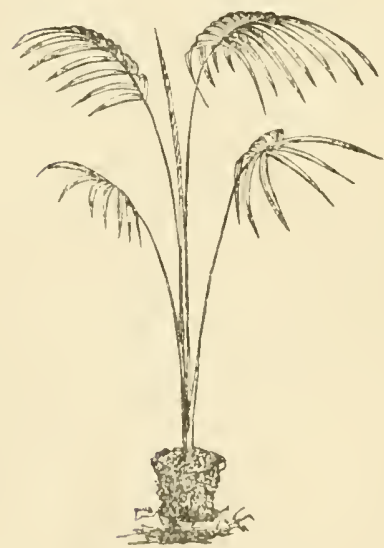

Diemonorops accidens.

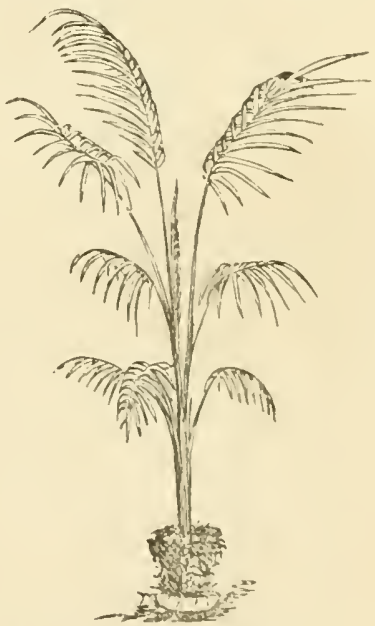

Dxmonorops palembanicus.

and Birmingham had plants put through them. At the former I had a graceful pair of Pteris tremula, and at the latter a pair of Chamedoreas. The accompanying illustration represents a plant of white Bourardia, with Ferns and scarlet Pelargoniums arranged romul the basc. All plants put through tables should hare some similar kind of arrangement round the base, otherwise they would look unfinished, and, indeed, anything but oruamental. 


\section{CHAPTER II.}

\section{FORYIS OF STANDS-MATERIALS FOR KEEPING FLOWERS FRESH.}

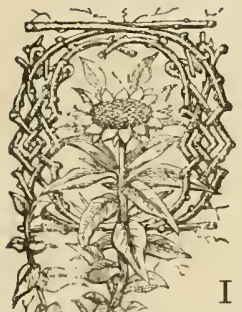

NE of the principal things to be decided, before entering farther into details, is the kind of stand in which the flowers are to be 'arranged; of these there are so many varieties that it would be impossible to enumerate all; I shall, therefore, only select those which I have in use myself, and with which I have taken prizes. One of my favourites is the March form of stand, with a trumpet rising out of the top tazza. This I have always considered most effective; it is easily dressed, and not expensire to purchase; its greatost fault (and one which bclongs to the true March stand) is, that the bottom tazza is scldom or ever in kecping, as regards size, with the upper onc ; to remedy this it will be found a good plan to have zine trays made of a size proportionate to that of the upper tazza; these trays should be about an inch and a half in depth, and should be painted green outside and white inside. The stand should then, after it has been screwed together, be placed in the tray, which, when packed with 
sand, will keep all perfectly firm; but should the stand, after being arranged, require to be moved from one table to another, it must be lifted by means of the zinc tray, and not by the glass stem, which would be done were it not standing in such a tray. The next form which claims attention is the high single trumpet with three curred branches or trumpets arranged round the centre one. This stand is suitable for placing on a platean of looking glass, as it has no dish or tazza at the bottom; in my opinion, howerer, it is always improred by haring some arrangement of flowers round the base, and, to effect this, it is a good plan to have a tray made similar in form to that just described, in which this description of stand can be quite as easily fixed as an ordinary March stand. My attention was first directed to this stand by Mr. W. Thomson, of Penge, whose taste in floral decoration is well known, and I have since used it constantly at flower shows, and on our own dinner-table; it cannot, howerer, be arranged so quickly as the March stand, but a little practice will soon overeome that difficulty, and, when arranged, it forms a very handsome centre-piece for the dinnertable. There is also a stand very similar to the preceding one, which has a tazza raised on a pedestal about 6 inches high, but, as this form is never made of as large a size as the first-mentioned, it is not so suitable for the decoration of a dimner-table, but it nevertheless forms a very clegant drawing-room rase. A high slender trumpet, rising out of a flat tazza, is another form of vase which is well suited for the dinner-table. The next which I shall mention is the common March stand, perhaps the best knowu of any, and one which is to be found in almost every household where floral arrangements are attempted, 
though I must confess that I am not such an ardent admirer of this form of vase as most people; on the contrary, I much prefer, as I have stated, a March stand, with a trumpet rising out of the top tazza. Before concluding my remarks on the forms of stands, \&c., I must not forget to mention the trays for placing round the bases of plants

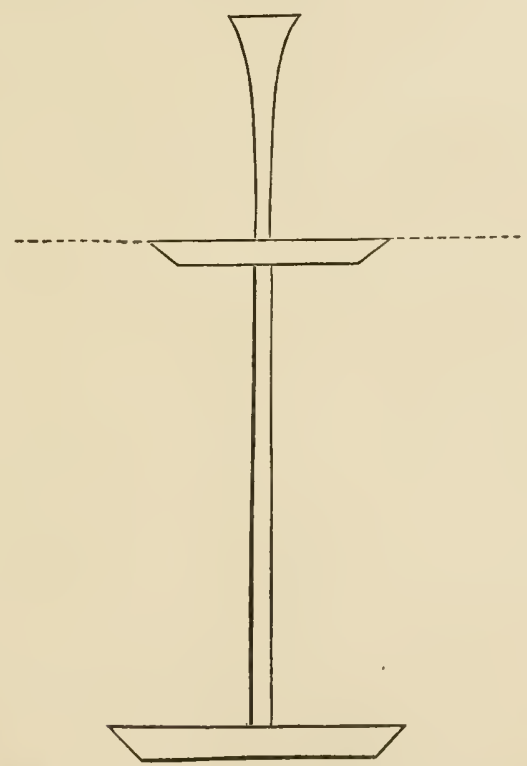

March stand furnished with moveable top vase.

which are brought through the dinner-table. These should be made of zine, about $1_{\frac{1}{2}}$ inches in depth, painted green outside and white inside, and of the shape represented in the accompanying illustration. After having arranged the flowers in each half, they are placed round the base of the plant, and by a little adjustment of the 
folinge the points of junction can be quite concealed. In purchasing stands, the brightest and clearest looking should be selected. This is not, howerer, of so much importance in the case of the March form as in that of

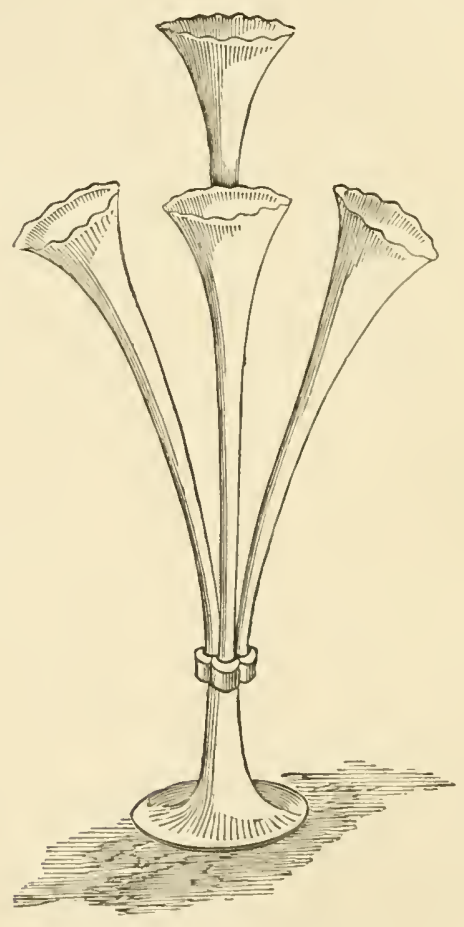

Compound Trumpet-stand.

some others, inasmuch as the tazzas are filled with sand, but where a trumpet or some such arrangement exists, transparency must be secured, and glass with flaws or marks on it would have a bad effect, and should be avoided. Another point worth remembrance, when purchasing 
stands, is to observe that those selected do not intercept the view across the table; for, no matter how handsome the flowers may be, or how costly the vases in which they are arranged, if they interrupt the view, everybody seated at the table would, if they were consulted, have them removed.

\section{Materials for Keeping Flowers Fresh.}

As a rule these consist of clay, sand, Moss, and water. For flat tazzas, or zine trays, such as described for placing round the stems of plants brought through the table, sand
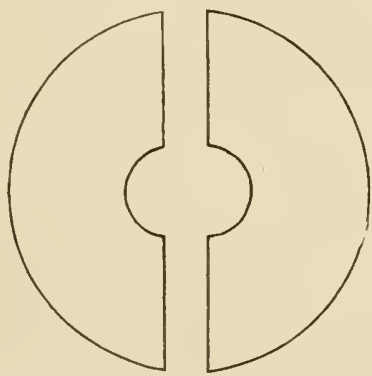

Tray for placing round the bases of plants.

or Moss should be selected; if the former, it should be Reigate or silver sand, though any kind may be used; but, should any portion of it happen to be seen, fellow or common sand has an unsightly appearance. Whon the tazzas or trays have been filled with the sand, the latter shonld be wetted by means of a small watering pot, which should hold, say a pint or a quart of water, a fine rose being used for the purpose, and the sand should be watered until it is quite wet. The sand must not, howerer, be made too wet, as in that case the stems of the flowers will 
not stand upright or where placed. If Moss be selected, that sold by florists in bundles is the proper kind; but persons living in the country may obtain all they require in this way in the hedge-rows or woods. In the case of bought bundles, when opened out, all leaves or other rubbish should be removed, the Moss placed in a basket, and put under a water tap, which should be allowed to run freely on it for some little time, so as to thoroughly cleanse it. When this has been done, the water should be pressed out of it, leaving just enough to keep the Moss damp and the stems of the flowers fresh. For filling the trumpets, spring water, if it can be obtained, is the best, but whatever kind of water is used, it slould be perfectly clear, as any little floating impurities are unsightly. Were I asked, "which is the best material in which to arrange flowers-sand or Moss?" I should reply, "one is about as good as the other." If the flowers are to last for any length of time, place their stems in Moss, but, if this is not important, then use sand in preferencc.

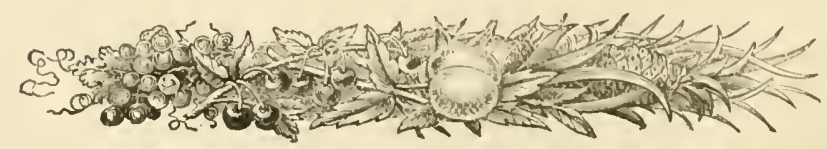




\section{CHAPTER III.}

\section{PREPARING, WIRING, AND GUMMING FLOWERS-KEEPING PREPARED FLOWERS FRESH.}

\section{Preparing Flowers.}

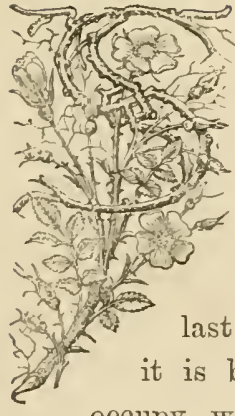

occupy, when first one petal begins to drop, then another, and, finally, down comes a little shower, and nothing is left of one's Pelargoniums or Camellias but the stems. This I have often seen oceur; but, by careful preparation, it can be easily avoided. The first thing is to avoid flowers which have been grown in a high temperature and where the plants have not been well hardened off before they were eut, and the same remark applies to Ferus, for, if the fronds are cut for use while the plants themselves are growing in the stove, they will shrivel up in about an hour after having been cut. In cutting the stems of both flowers and Ferns they should be 
severed with a sharp knife and not with seissors, as is generally done. By using a knife no bruising takes place, and the stems are better able to imbibe moisture, so as to keep them fresh. Whon arranging flowers it is a good plan to have a basin of water close at haud, and, before each Feru frond is placed in the position in which it is to remain, to dip it into the water, lift it out, and give it a gentle shake. This will apparently remove the water from the leaflets, but a number of globules will remain on them, though not observable to the naked eye, which will tend to keep them fresh. The water should be tepid, that is, just the chill taken off.

\section{Wiring Flowers.}

Many flowers, in order to keep them from falling to pieces, must be wired, an operation by means of which the stems ean be bent into any required position. The different kinds of wires for this purpose may be obtained in the Central Avenue, Covent Garden Market. Of these, I use four kinds, viz., two sizes of piercing wire, stubs, and bending wire. The three former are sold in bundles, cut in lengths, and the latter in reels. The piercing wire is that with which the different parts of a flower are sewn together; the stubs are nsed as artificial stems to flowers, such as Camellias, which are eut off short, and the binding or reel wire, is that with which the flowers are bound to the stubs. Such numbers of flowers require to be wired, that it would be impossible to enumerate them all, or describe the mode of doing each; I shall, therefore, select a few of those in most common use, and endearour to describe clearly the process of wixing them. I ought to 
have added, that a light pair of wire-eutters will be necessary to eut off all surplus ends; these may be obtained of any ironmonger, and the smaller and lighter they are the better, and both these and the wire should be kept in a small box in a dry place, so as to prevent them becoming rusty. Let us begin with the Camellia, a flower employed in all descriptions of floral decoration.

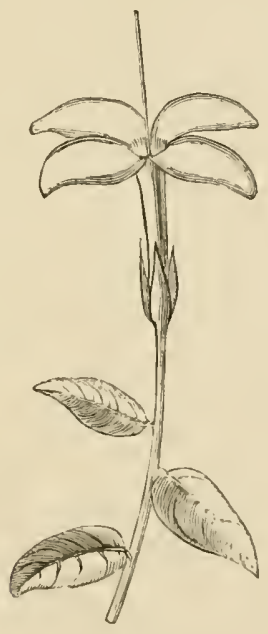

Bouvardia.

Suppose a box full of Camellia blooms were sent from some nursery, they would be found to hare been cut off without stems, and to make an artificial stalk, as well as to prevent the petals dropping, wiring must be resorted to. Let the bloom be lifted with the right hand, invert it, that is, turn it face downwards, and gently press it as if one were trying to fold the bloom in two; this, however, must be done very gently so as not to 
bruise the petals, or the flower will be spoilt; it should then be held in that position between the first finger and thumb of the left hand, and a single wire, the strongest of the piercing kind, should be run through its centre sufficiently deep to catch all the petals in the line in which it is inserted, but so as not to show in the centre of the flower when turned up. The bloom should then be half-turned round, pressed again in the manner just described, and another wire should be pushed through it, this one being put in so as to cross the other, and so on until four wires have been inserted, as shown in the accompanying illustration; then all the points of the wires should, be bent back until they meet, and being taken hold of by the right hand, should be drawn down between the first finger and thumb of the, left hand, close to the palm; even after the back of the bloom has come in contact with the hand, the wires should still be drawn down a little-but very gentlyan operation which presses the petals into their proper places. The wires should next be drawn close together, and one of them twisted round the others, in order to keep them firm and form a slight stem, which should be bound to a stub with some reel wire, a little damp Moss being bound in close to the flower so as to help to keep it fresh. The stem may then be cut as short as may be required, and the mounting of the flower is finished. Now let us take a spike of Hyacinth. This, in its natural state, is anything but useful for floral decoration; but, if the pips be picked off and properly mounted, they will be found to be excellent for many purposes, varying, as they do, so much in colour. Each pip should be pierced by two wires (crossing each other 
in the centre) of the finest piercing wire, the pip being held stem upwards between the first finger and thumb of the left hand; the four points of the wire should then be bent backwards and twisted together in the form of a stem. The pips may thus be mounted on a

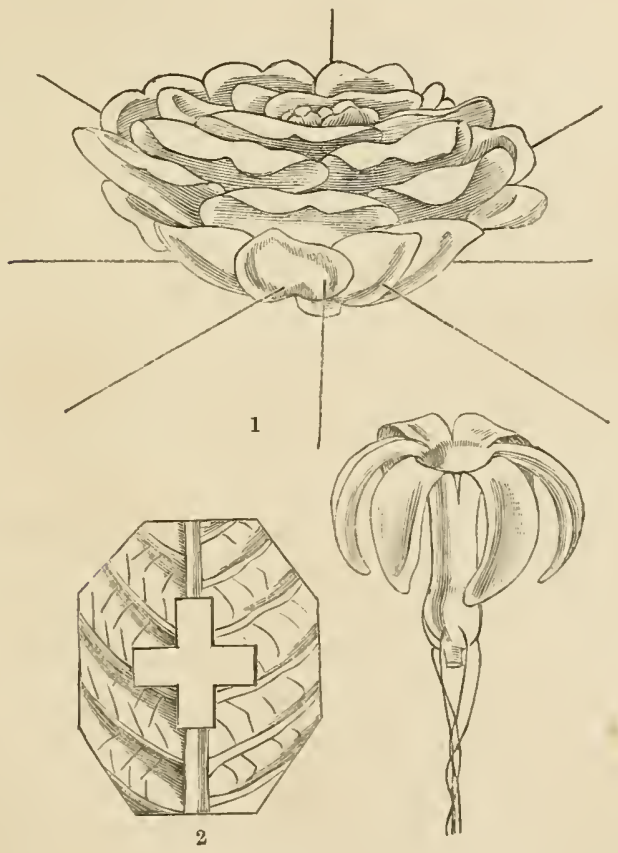

1. Camellia. 2. Laurel-leaf background. ${ }^{3} 3$. Hyacinth pip.

stem singly, or six twisted together, and then bound on to each stub. In just the same manner as the Hyacinth, the pips of Stephanotis are mounted; Bouvardias, however, are treated differently, on account of having long slender white tubes, which, if bruised or cracked in the 
least, soon turn brown, and of course their beauty is destroyed. The stem (or rather the branch, for sereral blooms are on each spray of the Bouvardia) should be held in the left hand, and into the centre of each open bloom, and down the tube, should be run one of the fine piercing wires; and, as soon as the bottom of the tube is reached, the wire should get a gentle push, so that the point may become inserted in the stem at the base of the tube. A pair of sharp scissors should then be taken, and the wire eut off in a line with the centre of the flower. The wire is never noticed, and it forms a support to the tube and keeps the flower in an upright position. These examples of wiring must suffice, though Orchids, Roses, and many other flowers, all require that treatment, into the details of which, individually, it is, however, impossible to enter.

\section{Gumming Flowers.}

This is another operation to which attention must be directed, as many flowers not wired require to be gummed, and some require both gumming and wiring; amongst others, for instance, the Bouvardia. Common gum will not answer; it must be made of shellac and spirits of wine, but can be purchased at the same shops as the wircs for quite as small a sum as if prepared at home, and that purchased ready made is always clearer than we ean ever make it ourselres. The gum should be always applied by means of a small paint-brush. First, let us take a Pelargonium as an example of one of the flowers which should be gummed. Gum the point of the paint-brush, and in the middle 
of each bloom deposit one drop of gam, which should be allowed to fall into the very centre of the blossom. Each truss, as soon as gummed, should be laid on one side before being placed in water so as to dry a little; for the gum, being made of spirits, quickly evaporates. Primulas and several other flowers are gummed in this manner. I shall, therefore, leave my readers to pick out such flowers as should be treated in this style and advert to such as require to be done in quite a different way. The Bouvardia and Azalea both, in place of having the gum dropped into the centre of the flower, like Pelargoniums, should be gummed outside, the gum being painted on with the brush where the flowers and stem join. To gum flowers neatly and well takes some little time and trouble, but there are several flowers which, if not prepared in this manner, would be otherwise almost useless; for, as soon as arranged, their petals would begin to drop. As with flowers which require to be wired, the selection of those that require to be gummed must be left to one's own discretion.

\section{Keeping Prepared Flowers Fresh.}

The best way of keeping flowers fresh after they have been prepared is to place their stems in water, and then to put away the ressels containing them in some dark cool cellar until required for use. Ferns should be kept lying in a pail of watcr, or else be well saturated in water and then shut up in au air-tight tin canister. In the latter way thcy will keep for days as fresh as if only just cut off the parent plant. Some flowers, such 
as the Gardenia, keep better, if cut off the plant and placed in water in some cool dark place, than if allowed to remain on the plant in the stove.

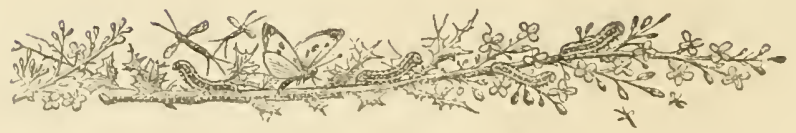


ARCHES.

\section{CHAPTER IV.}

ARCHES-DECORATIONS WITHOUT STANDS.

Arches.

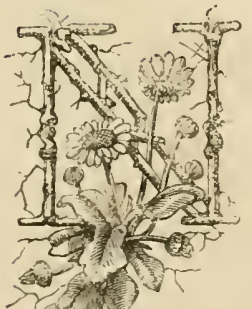

O way of decorating a dinner-table, if oval or circular, can be prettier than ornamenting it with a handsome arch, which is, moreover, by no means difficult to arrange effectively. It should, however, be remembered that, as a rule, no tasteful or elegant floral arrangement can be put together with. out a little trouble. The size of the arch itself must, as a matter of course, be proportionate to the size of the table on which it is to be placed; and, the size having been determined, next comes the material of which the arch is to consist. This should be strong wire, stiff enough to keep its form without bending, and each end should be inserted in a piece of iron or lead in the form of a large flat weight, which forms the stand. These supports shonld each be placed in a circular zinc pan, and packed in with damp silver-sand to keep them firm. Means are thus provided for having a group of flowers at the base of each end of the arch, which, 
together with the zine pans, should be painted green. The shade of green selected should be as near as possible that of the Ferns usually arranged round the edge. The next thing to be considered are the creepers with which the wire arch is to be covered. Of this class of plants there is such a variety (some hardy, others tender) that it would be impossible for me to enumerate all that are suitable for the purpose. I always use two plants of the Creeping Fern (Lygodium scandens) for arches. Each plant is turned out of the pot in which it is growing, the soil is shaken from the roots, and it is replanted in the zine pans of sand. This is a better plan than cutting off the fronds and inserting them in the sand, as, not being cut, they remain fresh for a much longer period than otherwise they would do. Through the Lygodium sprays of Lapageria rosea, or its white flowered variety, may be twined with good effect. On the centre of the table, under the arch, a pot plant is often placed, but I like best to see a small stand of flowers in that position; it must, howerer, be small, or it will detract from the effect of the arch. For this purpose, a small-sized flat tazza, with a trumpet rising out of the centre is best. Were $I$ about to arrange a table in this style, say in the month of June, I should select the following flowers:-Round the edge of the tazza I should arrange, lightly, fronds of Pteris serrulata, in the tazza itself some blooms, say two pink Cactuses, the same number of Water Lilies, a few sprays of pink and white Rhodanthe, and four fronds of Maiden-hair Fern. Down the trumpet I should twine a spray of Lygodium scandens, and in the trumpet itself I would put a plume of wild Grasses, Rhodauthe, 
and a few fronds of Maiden-hair. The arch I should cover, as I said before, with plants of Lygodium scandens, and in the pans I should arrange some of the flowers just named, with the addition of a few half-open Rose-buds, blue Forget-me-nots, or any other suitable flowers which may be at hand. Round the centre vase might be placed a few specimen glasses, each containing a Rose, bloom of Eucharis amazonica, \&c., each backed by a Fern frond. In some cases a plant is set under

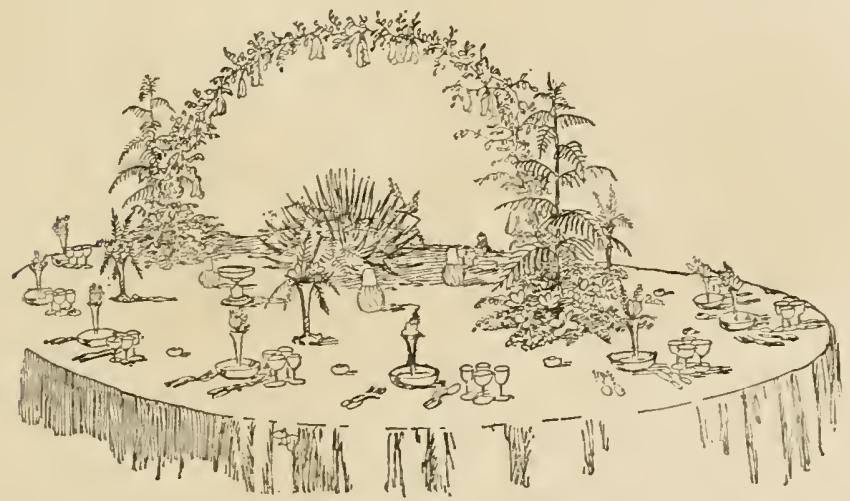

Dinner-table with arched decoration.

the arch, let through the centre of the table, and at the ends of the arch growing plants are often placed in the pans, instead of cut blooms. Those who do not have glass houses in which to grow Lygodium scandens or other creepers of that kind, might use in their places joung shoots of Iry, Japan Honeysuckle, or a spray of Passion-flower, and fill the pans or trays with whatever garden flowers are obtainable. Is is uscless for $\mathrm{A}$ to say to $B$, you should use so-and-so, and place this next 
to that, as perhaps $B$ may not possess half of the plants named by $A$. What, therefore, I wish to describe is how this style of arrangement would look best, should the flowers recommended be at command.

\section{Decoration Without Stands.}

This also deserves attention, as one gets tired of arranging the same stands day after day, and, unless one has a very long purse, indeed, rases cannot be constantly dressed afresh with flowers; I hare, therefore, had to manufacture (if I may so term it) stands of my own, the foundation of which is often a common soup plate, which if properly managed makes a charming stand. If I have friends at dinner, I use three plates; if for every day use only one. Let us first take three plates, which being obtained, the next important matter is to procure three good plants to stand in them. That for the centre should be much taller than the others, say a fine Palm, the others being. Adiantum cuneatum, one of which should be set at each end, an arrangement about as good as any that could be made. Having placed the pots in the plates, they should be packed in with damp silver-sand in the form of a mound, so as to hide the pot; the surface of the sand should then be covered with fresh wood Moss, or better still, if you have it growing, Selaginella denticulata. This done, the next thing is the arranging of the flowers, which I have done myself as follows; but it must be remembered that it was for a dinner by daylight, as many of the shades, if subjected to artificial light, would have lost their beauty. The pot plant which formed the centre 


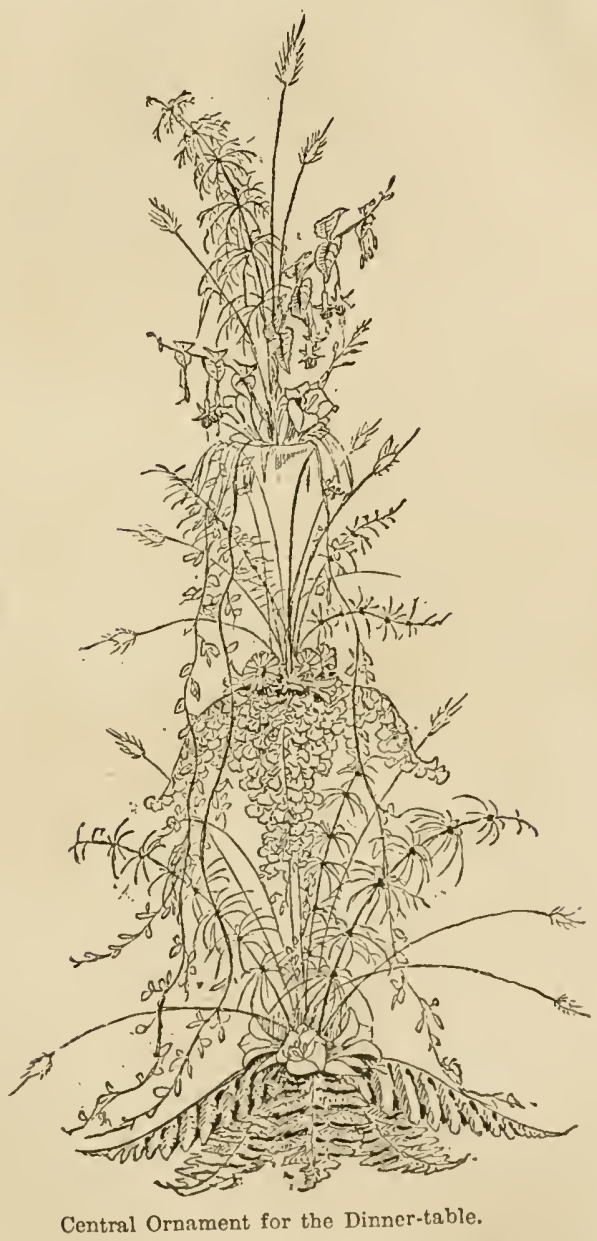

piece, was a well grown Cocos IVeddelliana. Round the edge of the plate $I$ had a wreath or fringe made of the fronds of Pteris serrulata, interspersed with a few leares 
of Cissus discolor. Round the base of the plant were then arranged Gloire de Dijon Roses, Christine Pelargoniums, pink Rhodanthe, some sprays of Iresine, and a few fronds of Maiden-hair Fern. The two end plants consisted of Adiantum cuneatum, and round their base I had some more blooms of Gloire de Dijon Roses; in place of the Pelargoniums, I had sprays of Bougainvillea, and I substituted some young brown shoots of Roses for the Iresine, finishing off round the edges with fronds of Ptoris tremula. With reference to the single stand, it was dressed in March, and was very effective by gas-light, to which, of conrse, at that season it was subjected. The pot plant which I employed on that occasion was Pteris tremula, and round its base I had white Primulas, scarlet Geraniums, and Begonias, Snowdrops, and Maiden-hair Fern, while round the edge were different varieties of Fern fronds. Sometimes the centre-piece is a March stand, which, some think, looks better than the threo alike; at all erents it makes a change, and where this arrangement is alopted a quantity of wild Grasses and Horse-tails may be nsed in the contre-picce, as well as in the end stands, with good effect. Nothing, indeed, tends to give such a light appearance to an arrangement of this kind, as plenty of wild Grasses intermixed with the flowers employed. In the end stands, Lily blooms take the place of the growing plants, and if the soil be kept damp, they will retain their freshness for a long period. Lilium lancifolium, both white and erimson-spotted varieties, are well suited for this purpose, more especially the white, a colour which does not interfere with any other with which it may be brought in contact. I 
have also seen Lilium auratum used for this purpose; but, though good, so far as form is concerned, its perfume is much too powerful, and many blooms of it in a room are nndesirable. As a rule, all very fragrant flowers should either be avoided, or, at least, be used in small quantities. 


\section{CHAPTER V.}

\section{PLANTS THROUGH THE TABLE-GROUPS OF MARCH STANDS-DECORATIONS FOR BUFFETS.}

Plants through the Table.

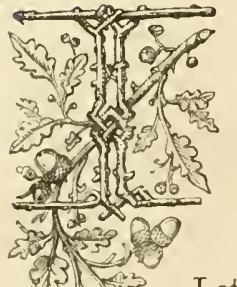

HAVE already described the manner in which plants are put through the table, and shall now treat only of the floral arrangements round their bases, taking it for granted that the zinc trays are fixed in their proper places. fis. Let us take the case of a dinner-table and laid for sixteen persons. If the centre-piece $s^{3}$ is a March vase, with a trumpet rising out of the upper tazza, it should be arranged thus:In the bottom dish searlet Cactus blooms and trusses of Stephanotis should be placed alternately with spikes of Astilbe (Spiraa) japoniea and Cyperas alternifolius; around the edge, resting on the table-cloth, should be fronds of Adiantum Farleyense and Pteris serrulata alternately. In the top dish shonld be pale-flowered zonal Pelargoniums, Lily of the Valley, and Maidenhair Fern ; in the trumpet, Astilbe (Spiraea) japonica, Rhodanthe Manglesii, small-flowered scarlet and pale pink Begonias, Maiden-hair Fern, long-trailing sprays 


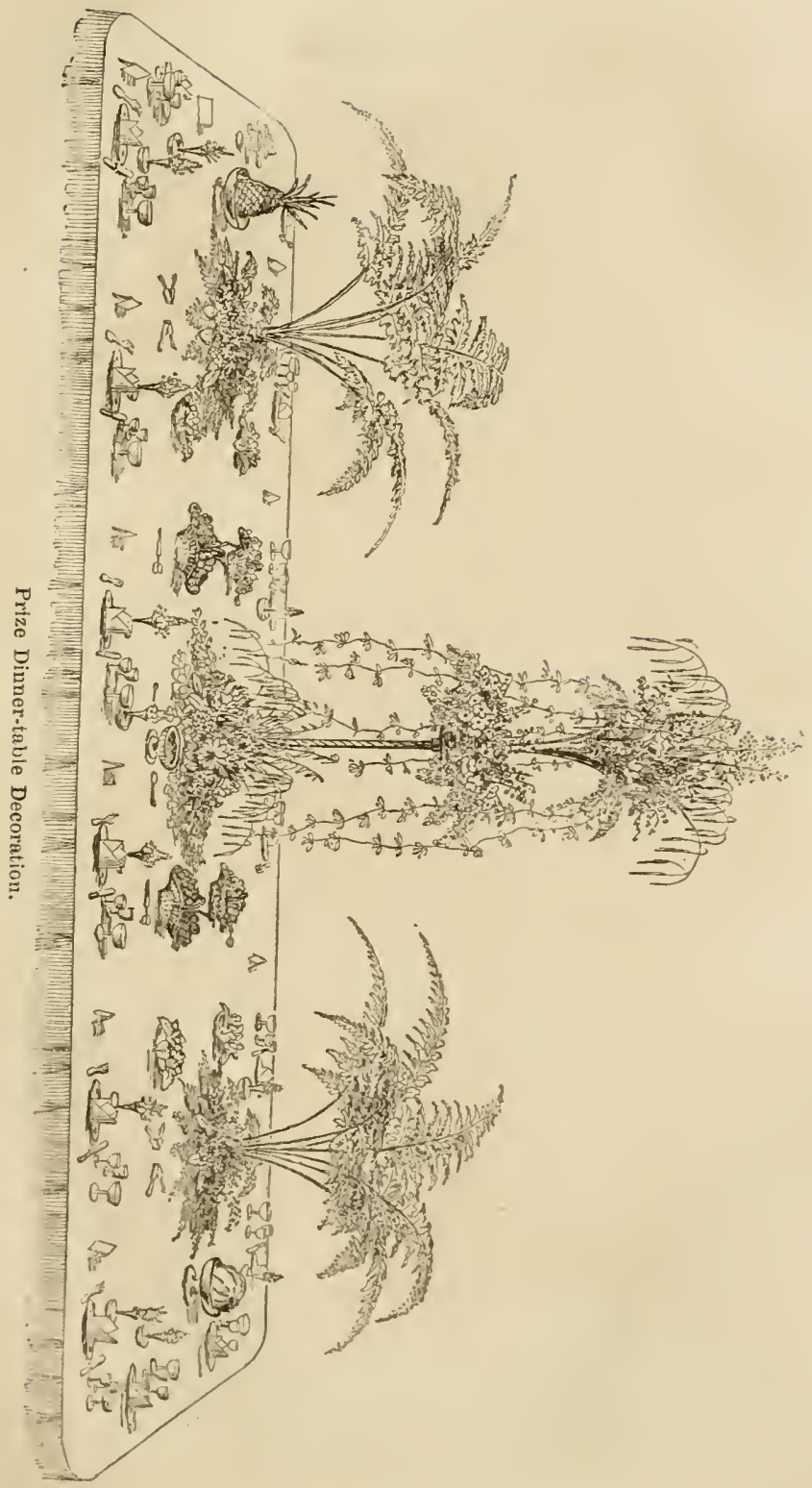



of Lygodium, and a few spikes of wild Grasses. The plants put through the tables should be Ferns (Pteris tremula), round the base of which should be arranged trusses of Stephanotis, white Rhodanthe, Maiden-hair Forn, and Lastrea Felix-mas. The baskets should be of glass, and might contain Grapes, two being filled with white, and two with black kinds, which should be set off with Ferns, a spray of Lygodium being also twined around the handle of each basket. There should be four oval glass dishes on the table, for Cherries and Strawberries. A Pine and Melon might be placed at the top and bottom, which, like all the other dishes of fruit, ought to be decorated with foliage; between the baskets should be small cireular stands or dishes for sugar. In front of each person might be a fingerglass, containing a button-hole bouquet, or coat-flower, of a colour to harmonise with those in the centrepiece, and on the surface of the water should lie double scarlet Pelargonium pips, and small leaves of the sweet-scented Geranium called. Lady Plymouth, the stem of each Pelargonium pip being inserted through the centre of the Geranium leaf, so as to keep it firmly in its place. This table is suitable either for daylight or gaslight.

\section{Groups of March Stands.}

The lighter March stands can be fitted, the greater is the effect prodnced, and for this purpose nothing is better than some of our wild field Grasses and Horsetails; the foliage of Asparagus may also be usefully employed in decorations of this kind. I once awarded 
a first prize to a group of three stands ornamented after this fashion. Their forms were alike, with the

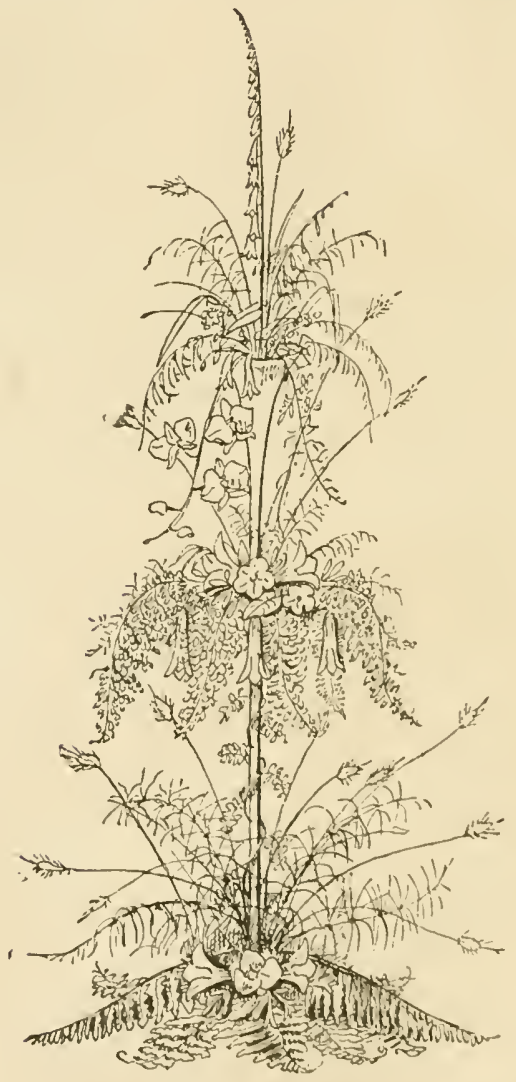

Centre Ornament for Dinuer-table.

exception of the centre-piece, which was the tallest, and which should always be the ease where three stands are thus arranged. But few flowers were used 
in their decoration; and yet they were very beautiful, and much admired by all who saw them. The bases of the stancls were concealed by a fringe of large Fern fronds, on which were laid Howers of the showy Eucharis amazonica and the brilliant Scarborough Lily alternately. From among these the beautiful blue buds and expanded flowers of Agapanthus umbellatus peeped here and there; and the effect of the lower parts was still further enhanced by the judicious use of Lagurus ovatus, and other graceful ornamental Grasses. The tier above was fringed with Maidenhair Fern (Adiantum cuneatum), beneath which drooped gracefully the beautifully-formed blooms of both the rose and white-flowered Lapagerias. The other flowers in this tazza were Eucharis and Vallota, with the addition of Franciscea calycina, Rondeletia speciosa, and blue Afriean Lily. The trumpet-shaped vases above were lightly filled with spikes of Chelone barbata, or scarlet Pentstemon, and light Grasses-the whole forming a most charming arrangement, and as good an example of a florally-dressed group of March vases as it would be possible to give as an illustration.

\section{Decorations for Buffets.}

The decoration of the buffet or sideboard forms an important point in the floral arrangements of the dining-room, and one not to be overlooked, though such is too often the case. Across the back of the sideboard nothing looks better than a handsome arch, formed of flowers and foliage; cut sprays ean either be employed for this purpose, the ends being inserted 
in wet sand at each end of the sideboard, or growing plants, one at each end, may be substituted, the pots being either concealed by ornamental cases or Fern fronds. Common Ivy forms a good foundation; so do sprays of Cobwa, through which flowering creepers may be twined. The latter must be selected according to the season of the year, but the former, I need hardly remark, are always obtainable. A large stand of cut flowers looks well when placed in the centre; and if a silver epergne, so much the better; for, though I dislike silver stands for flowers on the dinner-table, they are by far the handsomest for the buffet, where too much silver can hardly be grouped, provided that flowers and foliage are associated with it in such a manner that one sets off the other to adrantage. Flowers for stands on the sideboard should be large, and arranged with as bold an effect as possible. A rough block of ice, with Ferns and flowers round the base, a few stems of bloom inserted in the ice (little holes having been drilled for that purpose), and a few light sprays of Lygodium scandens lying over the whole, have a charming effect; but where this style of decoration is used, there must be some vessel employed, into which the water from the ice can drip. Well-grown Palms, Ferns, and flowering plants also look well, but small neat plants are the most effective, as, if large-sized, they tend to give the arrangement a heavy appearance. 


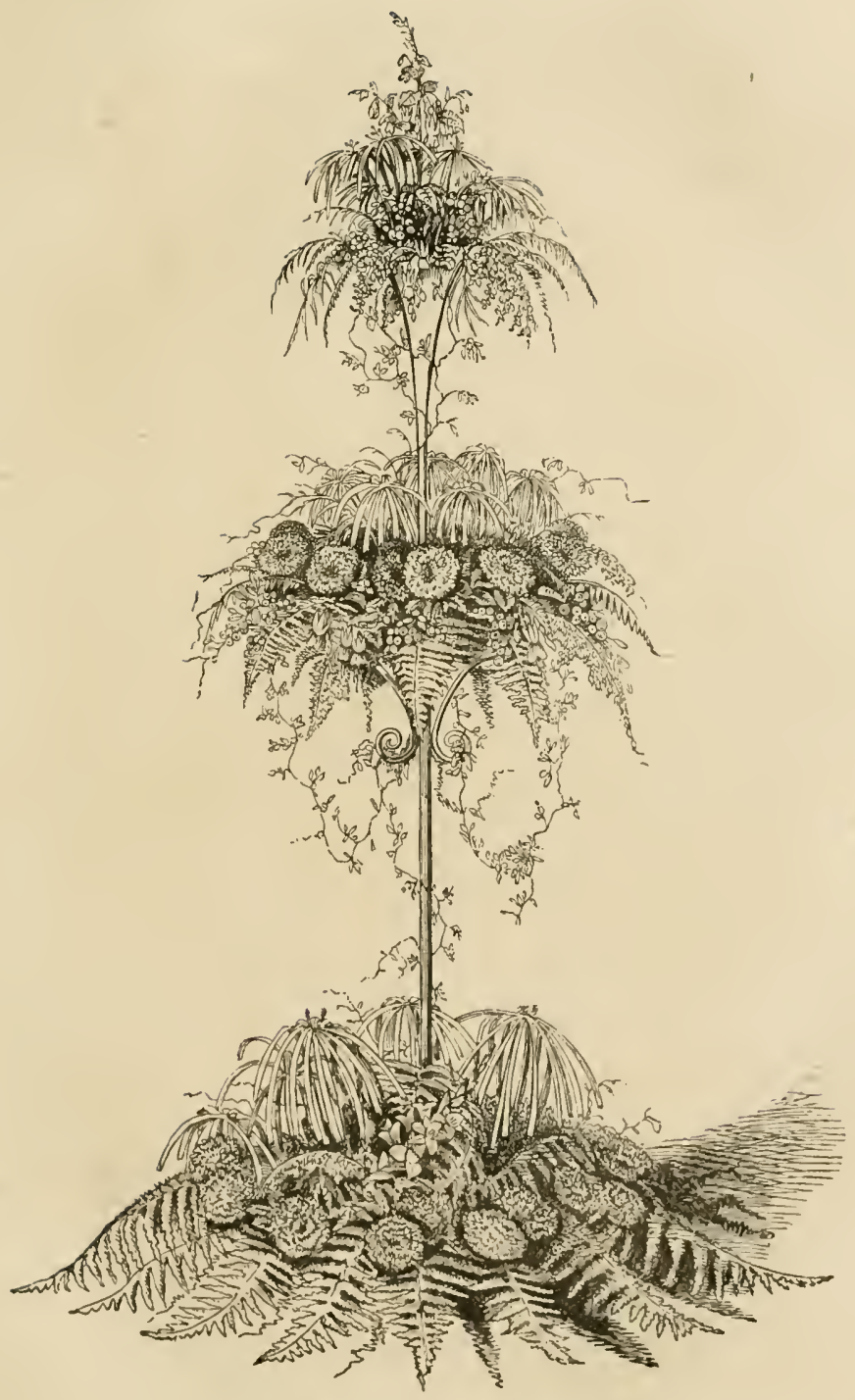

A Vase of Autumn Flowers. 



\section{CHAPTEP VI.}

TABLE DECORATIONS FOR CHRISTMAS DAY.

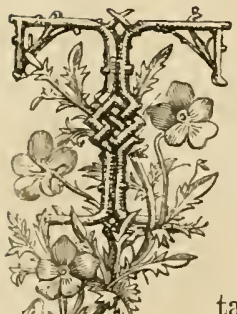

HIS is a day on which friends and relations hope to meet; therefore, a few hints on floral decorations suitable for the dinner-table at this season will not be out of place here. I will, therefore, gire descriptions of two tables, one for those who have plenty of choice flowers from which to cut, and another for those who may not have such an abundant supply at their command, or who do not care to go to much expense if they have to purchase them. Table No. 1 we will suppose to be about 12 feet, aud table No. 2 about 8 feet long, the width of both being in proportion to their length. As regards the decorations which I shall describe, it does not matter if the ends of the table be rounded, or if the table itself be oval, a form, indeed, which is more effective than a table with square ends. People are not, however, likely to change their tables for the sake of floral decorations; thereforc, I shall at once turn to table No. 1. Down the centre I should put three Mareh stands, with trumpets rising out of the 
top tazzas, the eentre stand being the highest by some inches; round the edge of the bottom dish of the centre stand I should place mixed varieties of Ferns, and four fronds of a golden one, reversed so as to show the gold side; in the dish I should put four large Arum blooms and four bracts of Poinsettia, and then fill in with white Heaths, Primulas, and similar flowers. Close to the glass stem which supports the upper dish I should place three large bunches of Holly berries, and up the stem twine a spray of a small-leaved Ivy. Round the edge of the upper tazza I should put fronds of Maiden-hair Fern to droop gracefully over, and through them mix some blooms of scarlet and white Lapageria, say two of each. I should next place in the dish four blooms of Eucharis amazonica, four sprigs of scarlet Bouvardias, and two of Holly berries, the latter to rise above the other flowers, close to the base of the trumpet, and the trumper itself I should finish off with Roman Hyacinths, scarlet Begonias, one small sprig of Holly, and Maiden-hair Fern. Through the flowers in the two tazzas, large fronds of Adiantum cuneatum should be arranged so as to wave lightly over them, and from the trumpet I should bring down four long sprays of Lygodium scandens to trail out on the table-cloth. The two end stands I would arrange in much the same style, using, say, in place of the Poiusettias, searlet Pelargoniums, and Camellias in place of the Arums; in the second tier I would substitute Azaleas for the Fucharises, and let the trumpets be filled with scarlet Begonias and Lily of the Valley. Round the edge of the lower tazza, 
some leaves of the variegated Iry can be laid out on the Ferns, here and there, with good effect, and plenty of Maiden-hair Fern should be mixed through the flowers. Between the centre-piece and the ends, stand two well-grown plants of Adiantum cuneatum, which should be dropped into ornamental china pots, and the surface of the soil should be covered with Lycopodium. Opposite each guest I should place, in a specimen-glass, a button-hole bouquet, made of flowers that will look well at night. Floating on the water, in the finger-glasses, I would put three leaves of the Oak-leaved Geranium, called Lady Plymouth, the centre of each being pierced by the stem of a pip of a double scarlet Pelargonium, so as to allow one flower to rest on each leaf. So much for the floral part; let us now turn to the fruit. Such a table as has just been described will require a good many stands of fruit-probably ten. At the top I would put a handsome Melon, at the bottom a Pine, with a few sprigs of Holly-berries arranged round the base of both the Melon and the Pine to indicate the season. Grouped round the centre-piece four glass baskets of Grapes, two light and two dark, would look well. There are now four more stands to be employed, and these I should have also of glass, of a flat oval shape, and filled with Apples, Pears, Waluuts, and Filberts, the Nuts and the Pear's and Apples being placed opposite each other. Any racant places on the table may then be filled in with smaller dishes containing crystallised fruits, ice, sugar, or anything else that may be desired. As respects table No. 2, a stand similar in shape to that described for 
table No. I would look well in the centre. A different one might be used, but a March stand is one that is to be found in almost every house where floral arrangement of any description receives attention. Round the edge of the bottom dish should be placed some fresh Fern fronds (hardy kinds), and on these might be rested some leaves of golden and silver varieties of Ivy; the dish should then be filled in with white Chrysanthemums, scarlet Pelargoniums, Laurustinus, Holly berries, Arbutus berries, white Lilac, and a few fronds of Maiden-hair Fern, whilst up the glass stern might be twisted a spray of variegated Ivy. Then from the edge of the second tier might he drooped some long sprays of Selaginella denticulata, and in the tazza itself be arranged some scarlet Pelargoniums, Jonquils, or any other scarlet or white flowers that may be at hand, and a few fronds of Maiden-hair. Round the mouth of the trumpet should be put some Selaginella, finishing off with a few light-looking scarlet and white flowers, Ferns, and Grasses, and two or three leaves of Pampas Grass, placed ontwards in a graceful wavy manner. Romnd this centre stand should be arranged eight specimen glasses, four of the nsual height, and four rather shorter; these should be filled with flowers similar to those nsed in the centre-piece. At the top and bottom, where, in the larger table, the two other stands wonld he, two well-berricd plants of Solanum Capsieastrum should be placed, the rongh pots being dropped into more ornamental ones, fresh Moss placed orer the soil, and three pods of Iris foetidissima pricked into each. Some white and black Grapes shonld be put at the top of 
the tables, and Apples at the bottom. Pears, Nuts, Medlars, \&c., or any other fruit it may seem desirable to add, can be then placed at the side, but its selection is left entirely to the discretion of others.

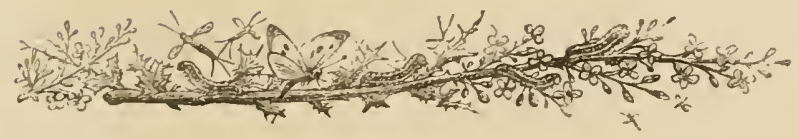




\section{CHAPTER VII.}

ARRANGEMENT OF FRUIT FOR DESSERT.

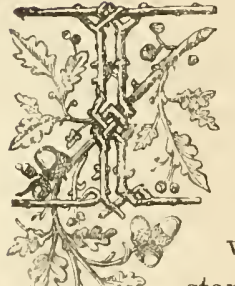

$\mathrm{N}$ the case of all handsome dessert services, six dishes are generally devoted to fruit, the lighest being intended for the top and hottom of the table; and, where additional dishes are wanted for mixing in amongst china stands, none are more suitable than gracefully-shaped glass baskets, oval-shaped glass dishes, which lay flat on the table, and small groups of Parian figures supporting dishes made of the same material. Monotony or sameness in the eharaeter of the stands should always be avoided; therefore they should be of different heights and shapes, the tallest being placed, as has just bcen stated, at the top and bottom of the table. The fruits generally selected for these end stands, when in season, are a Pine and Mclon; and they look best resting on a mat formed of Vine leaves, which, in autumn, when a little tinted, have a pretty appearance. In addition to the leaves, a wreath of Maiden-hair Fern may be arranged round the base of each fruit. Next in importance are Grapes, which, when Pines and Melons are not obtainable, take their place; but, at other times, I like to see 
them arranged in the glass baskets already referred to. The white and black may be mixed; but, if the baskets be small (which look much the best), I like one bunch of each colour in each basket, The baskets should be lined, if possible, with fresh green Vine leaves. Round the handles should be twisted a spray of Lygodium scandens, and among the fruit itself should be inserted a few fronds of Maiden-hair Fern and some Vine tendrils. Along with the white Grapes might be put a few tinted leaves of Virginian Creeper, and among the black a few variegated Maple leaves. These also associate well with Plums of the same colours, which look best grouped in flat oval dishes, and may be treated much in the same manner as Grapes; both Plums and Grapes must be carefully handled, or their delicate bloom becomes destroyed, and then much of their beauty is lost. Peaches and Apricots look handsomest in the Parian stands, resting on a mat of bright green Moss, and decorated only with a spray of Lygodium twined through thom, so as just to tone down their bright colours, but nothing more, their indiridual beauty being too great to be hid. Strawberries and Cherries also look well in these stands, and should be grouped in the form of pyramids (the stems being turned inwards), with leaves of the latter built up amongst them, the whole being decorated with fronds of Maiden-hair Forn. Greater variety still may be created, if required, by using some of the tropical fruits which are generally on sale in Covent Garden, such as Bananns, Figs, and Dates; Nuts also come in uscfully for such purposes. Then there are Apples and Pears, a few handsome fruits of which look wcll on an oval glass dish, decorated 
tastefully with Ferus or other foliage of a similar kind. Where fruit dishes are nsed ou the breakfast-table, I like them to be of ehina, as I think glass there looks out of place. The fruits nsed for this purpose consisting, as they do principally, of Stramberries and Currants, should be merely decorated with their own leaves. Where baskets of fruit are employed on the dinner-table, they look best arranged around the centrepiece. Stiffmess and formality, as regards the position of fruit dishes, should be avoicled as much as possible; for instanee, a straight line of dishes, running the length of a table, gives it a heary look. The only fruit which I dislike to see on a table are Oranges; not that I have any dislike to their taste, for nothing is more refreshing on a hot July day, after dinner, than a well kept Orange. It is the eolour to which I object, and which does the damage. It kills other fruit, flowers, and even the china, if the latter has any shade of yellow in it; and no amount of foliage seems to tone it down. The only fruit with which they associate at all well are purple Grapes, and Plums of the same colour. I have found the effect of my table so often spoiled by having Oranges on it, that now, when I want it to look partieularly well, I make it a rule not to have them plaeed amongst other fruits, but handed round with others different from what are already on the table. Many place flowers through their stands of fruit, and in some few eases the mixture looks well; but it will be found a good plan, where this is done, to insert the stems of the flowers in small glass tubes, such as are sold for coat flowers, filled with watera plan which also answers for keeping the Fern fronds 
fresh, if required for any lengthened period. Where the fruit is growing in one's own garden, it can be always so arranged that it is not gathered until a short time before it is actually required; in this way it loses none of its flavour, is fresh, and can also be gathered without being bruised; but when purchased in the market, this is not always the case, and all one can do is to select the freshest and best looking, bring them home, and place them in some cool place till required for arrangement. For decorating fruit some of the tinted leaves and branchlets of common trees and shrubs will be found most effective, as, for instance, the young browu leaflets of the Oak, the crimson shoots of the Wortleberry, or the crimson leaves of the wild Geranium, which, if growing on limestone, have unusually fine tints.

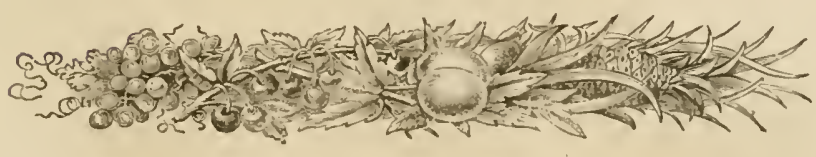




\section{CHAPTER VIII.}

VASES FOR THE BREAKFAST.TABLE.

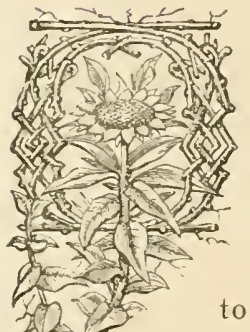

$\mathrm{N}$ the breakfast-table there should always be at least one vaseful of flowers, and as these will be seen by daylight, the decorator has a much larger number of blooms to select from than is the case when they arc to be subjected to the artificial light of the dinner-table. In summer such decorations should consist nearly altogether of hardy Fern fronds (or, at least, those which will remain fresh for some time after they have been cut) and wild Grasses, with only just a few flowers dotted through them, here and there, to gire colour as the flowers fade much sooner than the foliage, they can be removed when necessary, and fresh ones put in their places. Thus a variety of shades of green may be blended together, in such a way as to show up well, in contrast with the white damask cloth. I have seen very eharming arrangements made simply without flower's, Ferns and other foliage being used alone; but to make these effective is by no means an easy task, and should never be attempted by a 
beginner, as failure is sure to be the result. A little practice, however, and a good eye for colour, will soon overcome the difficulty. The following is one of the prettiest little ornaments for the breakfast-

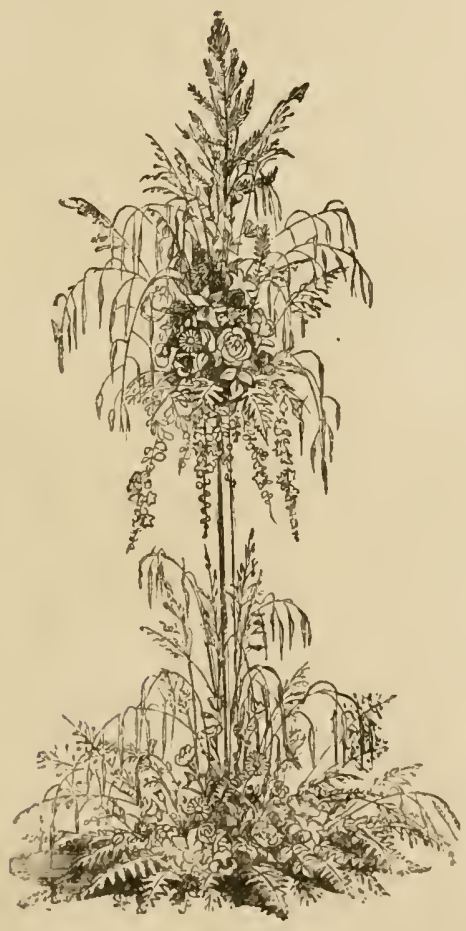

Vase decorated chiefly with Grasses.

table I ever put together. The vase which I employed consisted of a soup-plate, and in the centre was a plant of Cyperus alternifolius; round the edge of the plate I put a fringe of different varieties of Ferns-some of 
them golden ones-placed so as to exhibit the colour on the backs of the fronds; over the surface of the Moss I then arranged sprays of rich purple Cinerarias, white Azaleas, Lily of the Valley, and white Cyclamens with purple tips, a few fronds of Maiden-hair Fern being interspersed through the whole, and up the slender stems of the Csperus alternifolius ran a few slight shoots of Cissus discolor. Another pretty little vase, but of much smaller dimensions, I have often used during the summer months. It was a simple trumpet of white China resting amongst a cluster of silver rustic branches; in the trumpet I put white Sweet Peas, blue Corn-flowers, a few Fern fronds, and wild Grasses. This style of vase takes but very few flowers (an important point where there are not many plants to cut from); and, for a small-sized circular table, an arrangement of this kind will be found large enough. The next I shall describe is quite different from any to which I have set alluded; its form is well adapted for either the breakfast or dimner-table, and it would also be found, I have no doubt, to be a very elegant ornameut on a side table in the drawing-room, but as the decoration of the breakfast-table is the subject now under consideration, I shall confine myself to directions for dressing it for that purpose. In each of the tiny tubes grouped round the glass ball in the accompanying illustration a Moss Rose-bud might be placed, backed up by a few fronds of Fern, while the tazza may be filled with varions other kinds of flowers, and the trumpet finished off with a plume of Grasses or Ferns. Any style of floral decoration, indect, is acceptable on the breakfast- 
table; for, as a rule, not one in a dozen has a vase of flowers on it, while, on the contrary, one often meets with decorations on dinner-tables that might

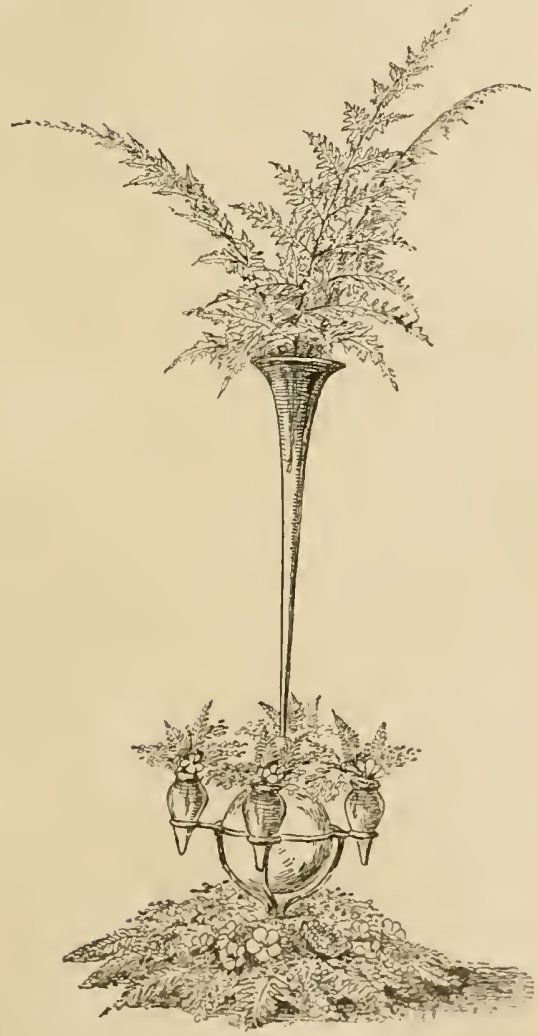

Tase ornamented chiefly with Ferns.

very well be dispensed with. Whenever possible, however, always have a cheerful raseful of flowers on the breakfast-table. 


\section{CHAPTER IX.}

VASES FOR THE DRAWING-ROOM.

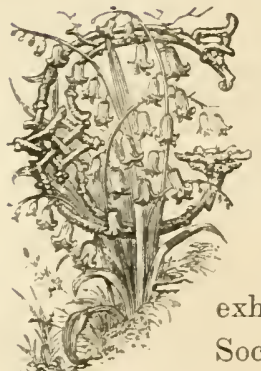

RACEFULLY grouped flowers in small vases, and a few specimenglasses placed here and there, are all that are required in drawingrooms, where large vases, I always think, look out of place. At the exhibition of the Royal Horticultural Society, held at Birmingham, I was fortunate enough to take the first prize for drawing-room decorations, with a trumpet-shaped vase having three curved branches, and dressed as follows: In the bottom dish or tazza, were three Water-Lily blooms, and some Maiden-hair Fern, the edge being ornamented with a few fronds of Lastrea Felix-mas; the three curved trumpets were filled with blue Cornflowers, Sweet Peas, Maiden-hair Fern, \&c., and the top was decorated in a similar manner, but contained, in addition, white Rhodanthe and wild Grasses; amongst the trumpets trailed long sprays of the pretty Lygodium scandens. A smaller stand, to which was also awarded a first prize at one of the Crystal Palace exhibitions, struck me at the time as 
being most elegant and chaste in form. It merely consisted of a very small flat glass dish, with a slight trumpet rising ont of the centre; in the tazza were three Water-Lilies, some green Oats, and a few Ferns; in the trumpet were Oats and Rhodanthe-materials of

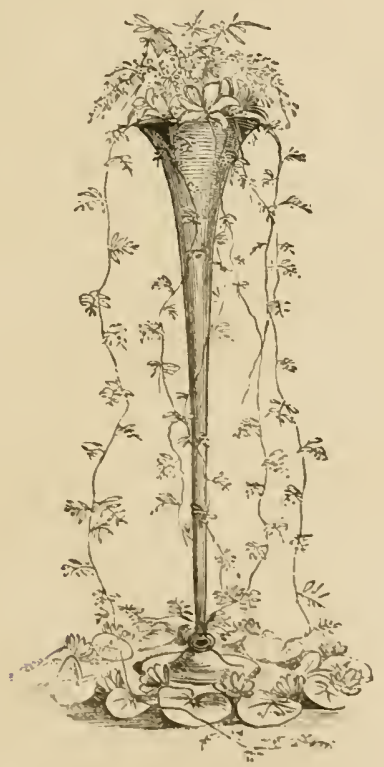

Trumpet-shaped Glass Vase, with Flowers and Trailing Fern, surrounded by Water Lilies.

no great importance, yet at few exhibitions has there been a more charming arrangement. I have even seen neat little stands, which consisted merely of an ordinary specimen-glass, set in a tea-cnp saucer. Thus tho saucer may be filled with yellow Rose-buds, Neapolitan Violets, leaves of swect-scented Geranimms, 
and a few fronds of Adiantum cuneatum, the edge being finished off with a thick wreath of Fern fronds; in the little trumpet or specimen-glass were placed a few sprays of Dentzia gracilis and Ferns. Specimen-glasses of a somewhat large size, with a few flowers placed in them, also form pretty decorations; but the flowers selected for this purpose should be of the best sorts, and perfect specimens of their respective kinds. One which I saw at the house of a friend,

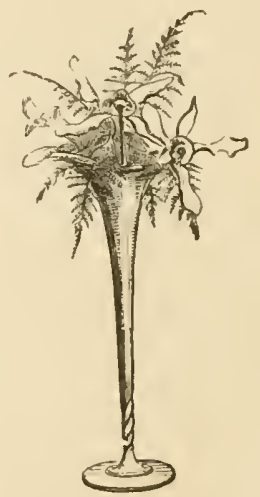

Vase with a few Orchid Flowers and Ferns.

and which I much admired at the time, contained some spikes of Cape Heaths, a bloom of Pancratium fragrans, and a few drooping bells of a small pink Cactus, the bouquet (if I may so eall it, thongh it was not tied) being backed up by some fronds of hardy Ferns; against these were placed the Heaths, then the Pancratium, and the Cactus blooms drooped over the edge, the whole being shronded hy Maiden-hair Fern. Orchids are flowers just suited for rases of this 


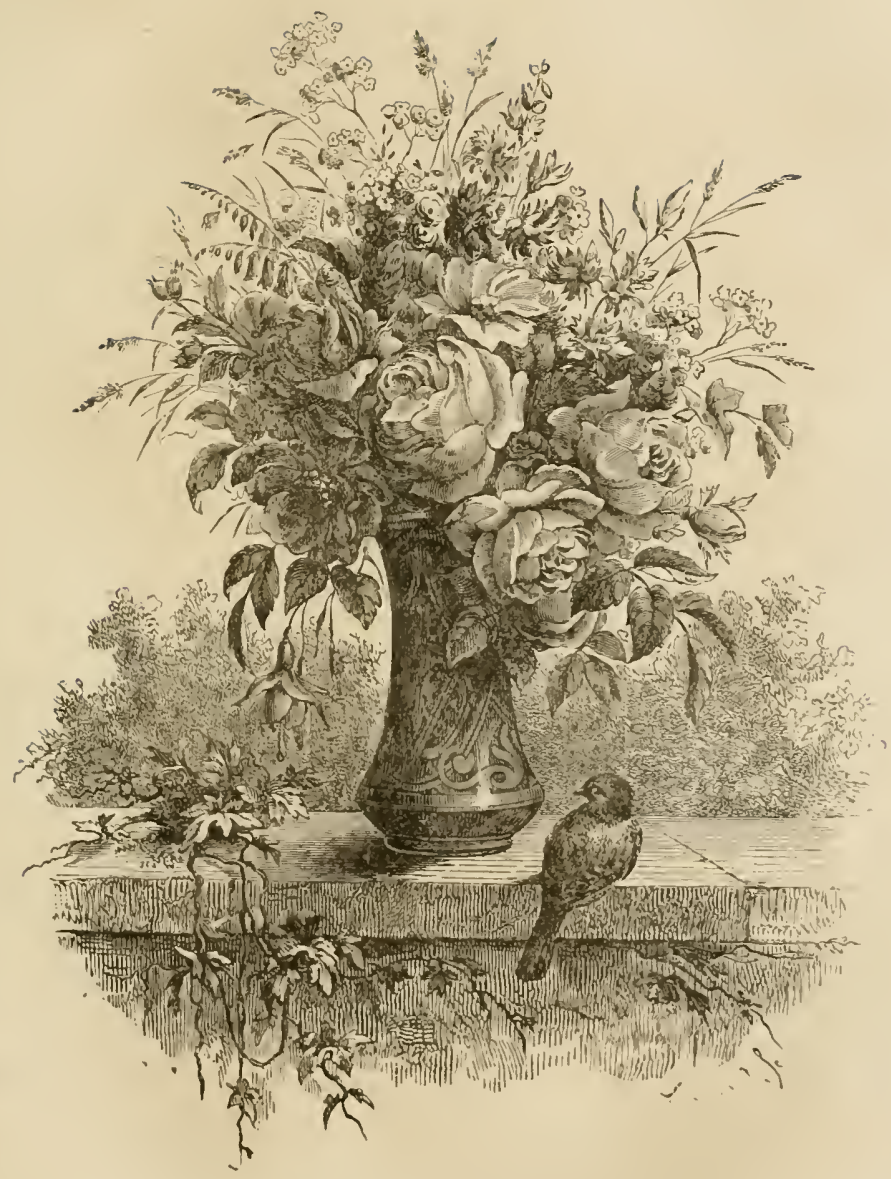

Small Vase of Flowere. 

description; what, for instance, looks more elegant than a few blooms of Dendrobium nobile, mixed with a few spikes of Lily of the Valley, set in a miniature bower of Adiantum cuneatum? Hyacinth glasses are

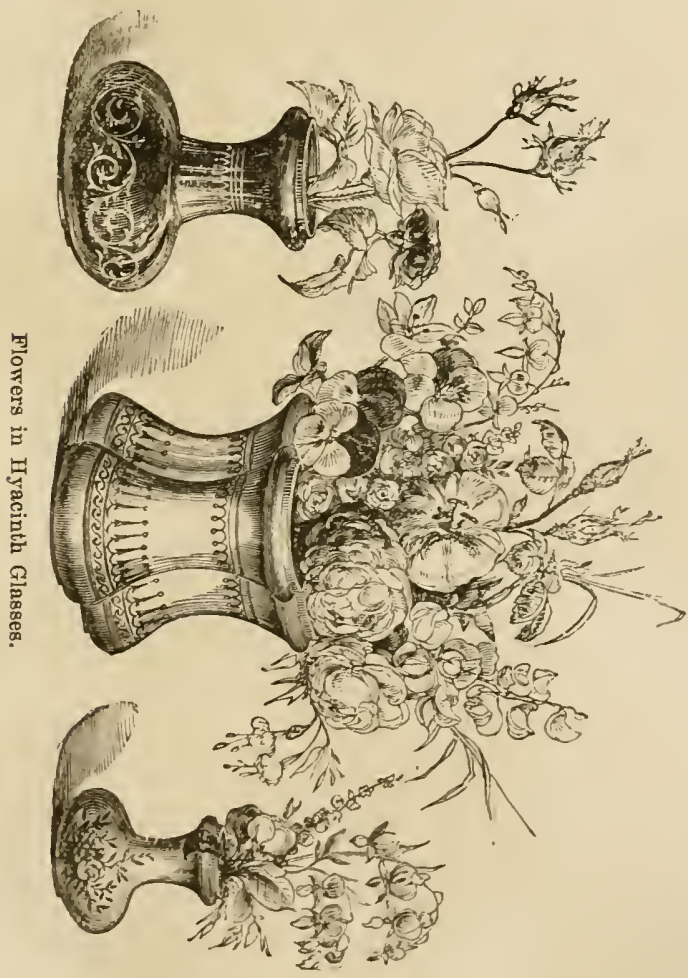

also very suitable for drawing-room decoration; especially those having opaque grounds ornamented with gold. Theso may contain larger blooms than those mentioned for trumpet-shaped glasses, as, for example, 
Roses, Fuchsias, Pelargoniums, Cactuses, and others; but, associated with these, as well as with flowers of smaller sizes, should be wild Grasses, so blended as to give a light appearance to the arrangement. Oats, in a green state, as I before mentioned, are useful for this purpose, though not so light looking as ordinary Grasses; both, however, may be purchased in bunches during summer in Corent Garden, therefore, both town and country readers have an opportunity of testing their value. When flower's are abont to be arranged in Hyacinth glasses, the darker and richer shades should be selected for flowers of a light colour, and lighter shades for dark flower's. A spray of such a Rose as the Duke of Edinburgh, placed in a white opaqne glass embellished with gold, looks well; so does the Gloire de Dijon in a purple or dark blue glass; the arrangement in vases (if I may so term them) of this kind need not, however, be limited to one variety of flower. A white or tinted Rose, in the style of Souvenir de la Malmaison, with a spray of Dielytra, one or two blue Forget-me-nots, and a few Grasses and Ferns would form a pretty mixture. Some of these glasses may be purchased in the form of three combined, as shown in the accompanying illustration; when such triplets are used, of course more flowers must be employed in their decoration, such as Roses, Lilies, Sweet Peas, Fuchsias, Pelargoniums, Dielytra, and Ferns and Grasses of various linds. The smaller vases are well adapted for mantel-piece decoration, or for small tables. The large kinds may be placed in the centre of a table of greater size, or a group may be formed on a sile table. For a small breakfast- 
table one of the larger-sized vases would form a pretty centre ornament with a few small specimen-glasses grouped round it. A pair of such glasses in Etruscan ware, if filled with ent flowers of light-coloured shades, would be well suited for the decoration of the buffet, or chimney-piece in the dining-room; but, like the flowers, the selection of the vases should be left to the decorator's own taste.

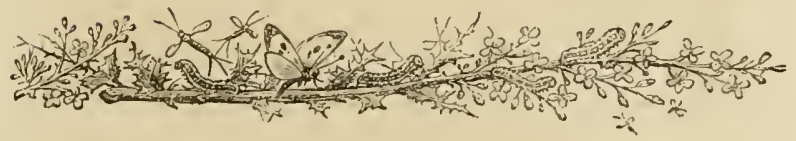




\section{CHAPTER X.}

MANTEL-PIECE DECORATION-SCREENS FOR THE FIRE. PLACE-WREATHS AND GARLANDS.

Mantel-piece Decoration.

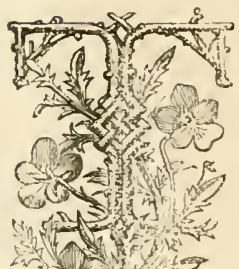

HIS is an important matter as regards the decoration of the drawingroom, and one to which special attention should be paid, as rases on mantel. pieces occupy rer'y prominent positions, and, miess skilfully furnished with flowers, axe better dispensed with altogether. Specimen-giasses, filled with Everlastingr, Tosc-buds, Pelargoninm blooms, or similas flowers, may be secn on every chimneypiece, and they are almost invarially onc-sided, that is, they face the room; all that is left for the mirror behind to reflect being the backs of the flowers or leares, in place of an ariangement as good as that exhibited in frout, which should be the case. As regards the ends of the mantelpiece, the first lhings to obtain are stands in which the flower's are to be arranged; these may be had of rarions shapes; but those best suited for this pulpose are a pair of common zinc troughs, each about 10 or 1:2 inches long, 
5 inches wide, and $3 \frac{1}{2}$ inches deep, painted green on the ontside and white on the inside. When about to be dressed with flower's, they should be filled with sand to within half-an-inch of the top; the sand should be then damped and covered with common Selaginella. If too much water be put on the sand, the flower-stems will not remain firm or upright. It is a good plan to have two pairs of these zine troughs, one pair in use in the drawingroom, and the other pair with the Selaginella growing in them in the greenhouse. By this means, as soon as the flowers in the pair in use have faded, that pair may be removed to the greenhouse and the other pair introduced into the drawing-room, and arranged with fresh flowers. The greenhouse treatment soon revires the Selaginella, impaired in appearance by indoor confinement. This plan also holds goort in the case of many other kinds of fioral decorations in which zine troughs or trays are employed. Round the edges of the troughs Fern-fronds should be used, and arranged so as to droop over and hide the sides as much as possiblc. The best kind of Fern for this purpose is the cornmon Brake, which is sold in florist's shops in bundles; should the fronds be found too long, they ean be ent as short as is necessary, and the top cnds nsed. After the Ferns have been rightly placed, the flower's should next be arranged, and rather large and bold-looking varieties should be nsed, such as Roses, Lilies, Clematiscs, \&c. These should be placed so as to stand out well one from the other, avoiding all appearance of crowding. Branches of Fuchsias look effective mixed with such flowers as those mentioned, and plenty of folinge must also be 
intermixed with them. When the flowers have been arranged according to taste, the troughs should be placed on the mantel-piece, one at each end, and close to the margin of the ledge; some long sprays of trailing plants should then be inserted in the soil and allowed to droop down at each side. Sprays of Lapageria rosea, Clematis, Hops, Passion-flowers. Tacsonias, and similar material are admirnlsy suited for this purpose, as are also different kinds of Iries, whieh are light and graceful, and obtainable at all seasons-a great point in their faronr. Those who do not eare for troughs of growing Selaginella, may use, instead of them, a pair of those small china pots sold at glass shops for standing on brackets and holding eut flowers. I do not mean such as are sold for dropping pot-plants into, as the latter hare always a hole at the bottom for drainage; the pots to which I refer are made on purpose to hold water in which to put flowers, and, in these, very effective arrangements can be made in the same way as that deseribed for the troughs, but they can nerer be made to look as suitable in shape as the troughs. At nearly every season of the year we hare flowers adapted to this style of decoration. In spring we have Hyacinths, Tulips, Forget-me-nots, Snowdrops, Squills, Lily of the Taller, Lilnes, fe.; in summer, Roses, Pelargoniums, Fuchsias, Water Lilies, and Clematis ; in autumn, Japanese Lilies, Roses, Lapngrerias, and Pancratium fragrans; and in winter, those who have no glass-houses of their own, can obtain in the market Cape Heaths, Chrjsanthemums, Callas, Poinsettias, and similar material. All these are 


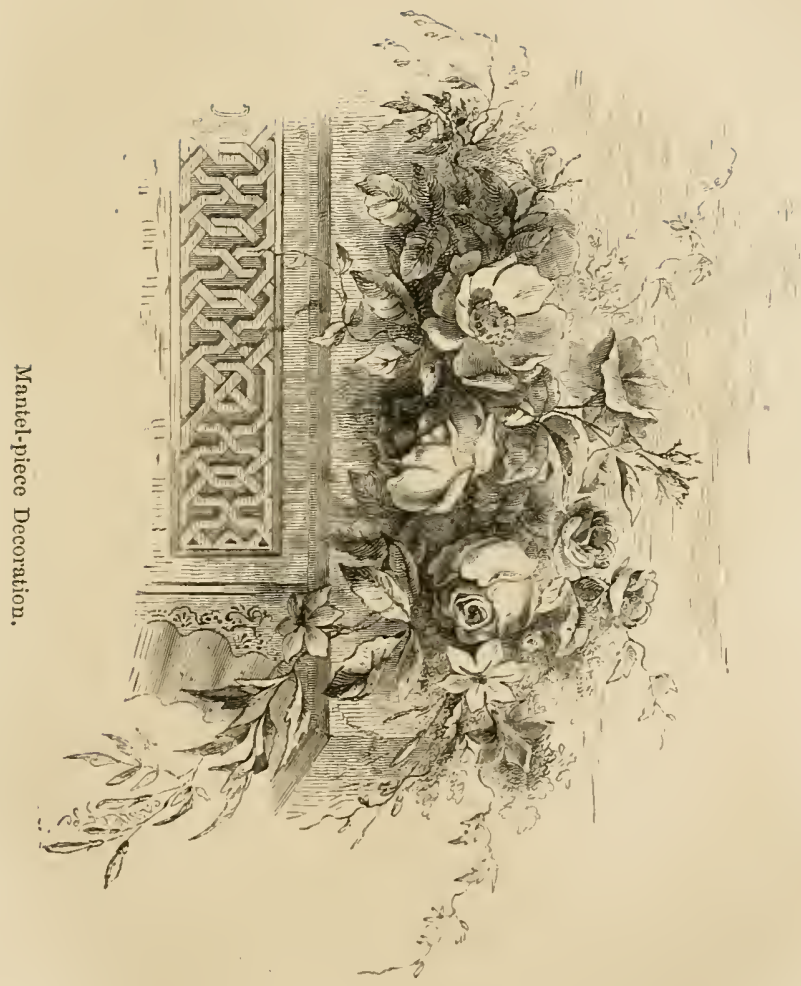



suitable for this style of decoration. Specimen-glasses with a few flowers and Ferns also look well on the mantel-piece, if dressed all round, but not if arranged to face only one way. A hand holding a rase, in china, is a pretty device for a few choice flowers, such as Orchids and Gloxinias; and, as a rule, richly coloured flowers are best suited for opaque vases, their decp tints being shown off to much better

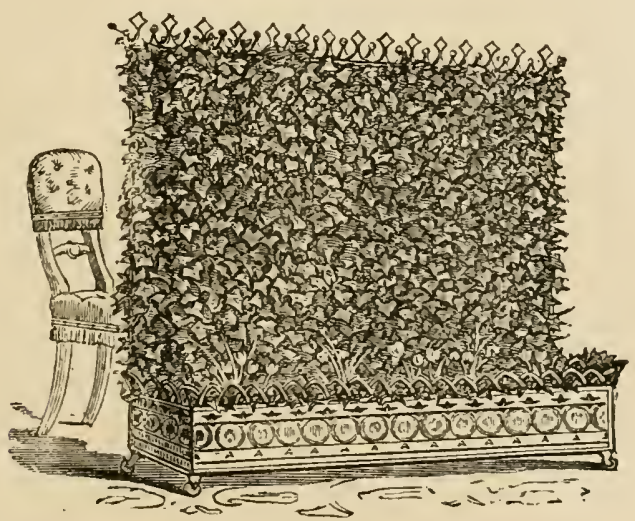

Ivy Screen for Fire-place.

adrantage on that kind of surface than on any other.

Screens for the Fire-place.

During the summer season, when there are no fires in the drawing-room, tastefinlly-decorated screens fitted into the fire-place hare a charming effect. These often consist of looking-glass and specimens of dried Ferns; but, as they do not come within my range, being dried, I shall pass them over, merely remark- 
ing that, though handsome, they are expensive. The best plants with which to corer screens are the common or variegated Ivies. First, a box should be procured, the width of the fire-place, to stand inside the fender; it should be made either of zine or rood, and should be ornamented with coloured tiles-in fact, a box such as one sees on hundreds of windowledges; at each end, in the back corners, an upright iron rod should be fixed sufficiently high to mect the ornamental marble orer the grate; between these rods a piece of fine wire netting should be strained, so as to form a sereen on which to train the Iry; this wire back should completely corer the iron $\mathrm{Or}^{\circ}$ steel grate; over the holes in the bottom of the box some broken crocks should be placed, and orer the crocks should be put a layer of Cocoa-nut fibre; then the box should be filled in with a mixture of rotten turf and sharp gritty sand. Some plants of Ivy should next be procured and planted firmly and rather thickly in the box, so as at once to corer the sereen. Along the front of the box, set on the soil, may be pot plants, or the surface of the soil might be covered with Selaginella denticulata intermixed with cut blooms of large-sized flowers.

\section{Wreaths and Garlands.}

These rank among the prettiest styles of indoor floral decoration, their only drawback being that some practice is wanted to make them light-looking. Long pieces of wire are required for the foundations, and some bundles of Moss to kecp the stems of both Ferns 
and flower's fresh. There are so many flowers suitable at all times of the year for this kind of decoration that I need not enumerate them, as the selection must depend on the size and description of the wreath or garland intended to be made; and, as a rule, light and airy-looking flowers are the best to select. As each flower is bound on to the foundation, after having been previously wired, it should be drawn ont into the required position, and plenty of damp Moss should be bound round the stem of each to preserve its freshness. For small sprays use very little Moss; for, were it to appear, it would tend to make the wreath look heavy, but in a large garland

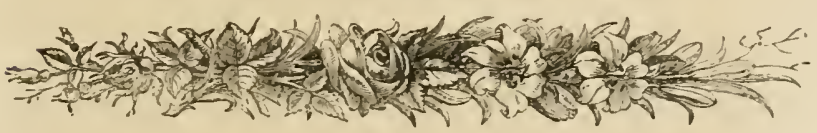

its appearance does not matter so much; indeed, if the Moss is fresh and green, its being shown will be an advantage. Though the Moss should be damp, permit no water to remain therein beyond what does so when it is pressed after being washed; if water be allowed to drip from it, it would spoil anything the garland might happen to touch. $A$ few sprays of Lygodium scandens look light and elegant twined through wreaths of any description. Heary flowers should, as a rule, be aroided; as, though in themselves they may be handy, they tend to give a heary appearance to the wreath, which no amount of dressing with Ferns or other foliage will remove. I am of opinion 
that if fewer Camellias were employed, and other flowers more plentifully substituted, snch as Bouvardias, Stephanotis, \&c., wreaths that are exhibited in the florists' windows would often have a lighter and more elegant appearance than they now sometimes present. Sprays of Iry intertwine charmingly in this style of decoration; but young sprays of a good colour, and with small leares, should be selected. Another creeper admirably suited for this purpose is the Japan Honeysuckle. This style of decoration is very effective where pot plants or vases of flowers cannot be employed.

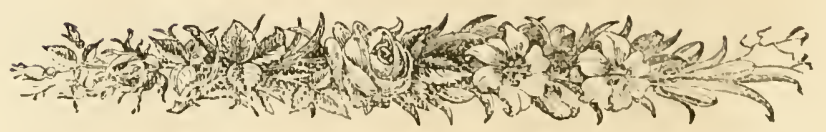




\section{CHAPTEP XI.}

BASKETS OF FLOWERS-A VASE OF ROSES-TO ARRANGE VIOLETS EFFECTIVELY-ORCHIDS FOR VASES.

\section{Baskets of Flowers.}

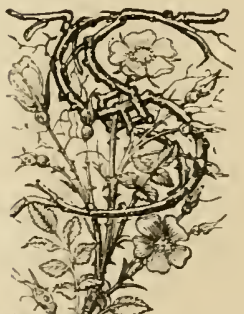

MALL baskets of flowers, if neatly arranged, form attractive ornaments on either the drawing-room or diningroom table. Such baskets may consist of glass, china, or wiekerwork, according to the taste of the purehaser. If of wicker-work, zinc pans should be made to fit into them, to hold damp sand or Moss in which the stems of the flowers are to be placed. Clear glass, however, in my opinion, shows up the eolonrs of flowers and the variously-tinted foliage of the plants better than any other material; next to glass, I like plain white wicker baskets of graceful shape. In glass baskets the flowers should nestle among fresh green coloured Moss, instead of sand, which, when seen through glass, has a bad effect. In the case of wicker baskets, however, either material may be employed. The selections in reforence to colours and flowers must be, of course, according to taste ; some prefer Roses all of one colour, such as erimson; 
others like white and pink, and some mixed colours. Maréchal Niel may be used in such baskets with good effect, both in the form of half-opened buds set off with their own foliage, and the joung brown leaves of other Roses. Round the handle of Rose baskets of this kind, may be twisted a spray of Lygodium scandens, but a piece of rariegated Ivy, Japan Honeysuckle, or anything of that kind wonld look quite as effective. Some mix different Ferus with Roses in preference to using their own foliage; but I like their own leares best when the arrangcment consists wholly of Roses; if for mixed flowers, then light fronds of Fern may be used with adrantage. Nothing is more effective mixed through all lkinds of arrangements in which yellow Roses are employed, be they blooms of Maréchal Niel or of Gloire de Dijon, than the joung flower shoots of the common climbing Rose, so much employed for covering fences, $f$ c.; the deep brown of the foliage making the yellow Roses look even more lovely, when in close contact with it, than they otherwise would be. I have arranged a small glass basket with pink Moss Rose-buds and trusses of Stephanotis, the whole being toned down with light fronds of Maiden-hair Fern; no other Fern did I use, even round the edge and across the handle, and I felt much pleased with the result. The fronds which I employed for twisting round the handle, being many shades lighter in colour than those nsed in other parts of the basket, relicred the sameness it might otherwise have had. In a small wicker basket, onc single Water Lily, with a few sprays of 
blue Forget-me-nots, wild Grasses, and a few fronds of such British Ferus as Asplenium Adiantum-nigrum, A. Trichomanes, A. marinum, and Blechnum spieant, or even the tips of the fronds of the Common Brake, have a fine appearance. In an arragement of this kind a small spray of light-coloured variegated Iry might be twisted round the handle with good effect; but the variegation should be silvery, not golden, as

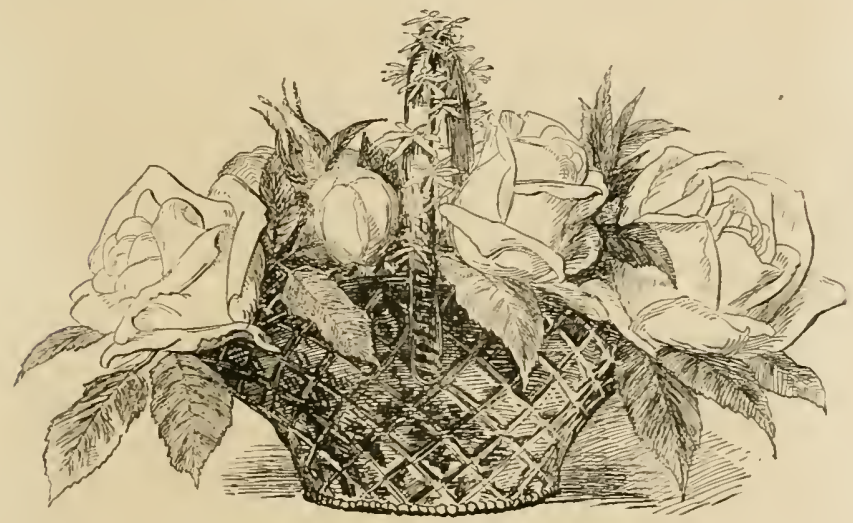

Basket of Maréchal Niel Roses with foliage.

the latter wonld not look well placed against the pure white of the Lily.

\section{A Vase of Roses.}

To arrange a vase of Roses effectively is no easy matter. At many hortieultural exhibitions a elass is devoted to vases and epergnes of Roses, in which no. other flower is allowed to compete, but any foliage that the decorator may be pleased to select mar bo 
added. I have seen many such stands staged, and when I first began to exhibit, I took a prize for one at the Crystal Palace in this elass myself; but I can look back now, even to my own, and come to the conclusion that none of the exhibitions were so good as they ought to have been. All had the same heary packed look, as if each exhibitor's great object had been to see how many dozen Roses could be packed into each tazza. After many trials in different ways, I find that no vase of Roses can be made to look well, unless each bloom and leaf have been previonsly wired. This may appear to be a heary nndertaking, and so it is, but the result will never be happy unless each leaf can be bent into any required eurve, just as an artifieial one is managed. Down the stem of the Rose should also be bound a stub wire for the same purpose. The advantages of mounting Roses on wires is as follows: - They can be bent out into any shape required; they stand up more firmly than they otherwise wonk do; and last fresh just double the length of "time they wonld if not so treated. Having before explained how a Rose shonld be wired, I need not again go over that ground. In arranging a March stand of Roses, each tier should be well shaded off, as this gives it a pretty appearance. Lay in the bottom dish deep pink and yellow kinds; in the upper, lighter shades; and the trumpet should be filled with buds of a still lighter tint; crimsons shonld be arranged in the same way. No flower looks handsomer, or is more useful for decorative purposes, than the Rose ; but, to make it so, it must be treated as I have above described, wheu the tronble will be well repaid by the effeet produecd. 


\section{To Arrange Violets.}

These charming little flower's are difficult to arrange effectively, owing to the slendermess of their stems, but this diffieulty may be obviated; and Violets, when properly treated, will last in perfection for a considerable length of time. The usual way of attempting to keep Violets fresh is to put them in water, tied up in a buneh as when bought, but, as the stems are never all of the same length, only about half of them reach the water, and the other half become withered, eausing the whole bunch to be thrown ont as dead, whereas only half of it is in that eondition. The style in which I like best to see these these simple little flowers arranged is as follows :-Take an ordinary sancer and fill it with fresh-looking Moss, such as grows by the roadside, and which has been previonsly well washed; build up the Moss in the form of a little mound in the saucer, keeping the fresh points of the Moss to the front, so as to make it look as fresh and relret-like as possible. The water should be well pressed out of the Moss, but enongh moisture should be left in it to keep the flower-stems plaeed in it fresh. Round the edge of the saneer Fern fronds should be arranged so as to hide the china, and for this purpose the tips of the common Brake are best. Take the Violet blooms, make them into bunehessay eight or ten in each bunch-and bind their stems together with a piece of binding wire; kecping the stems together makes then firm, and renders them capable of being bent into any position required. 
When a sufficient number of these little bunches hare been made, they should be dotted orer the groundwork of green Moss. A few Snowdrops, if procurable, placed here and there amongst the Violets, produce a charming effect, and a mixture of white Violets adds to the appearance of an arrangement of this description. The addition of a few fronds of Maiden-hair Fern, too, tends to lighten the general effect. The Moss should be well damped erery morning, and, if this be not forgotten, the Violets will keep fresh and emit their sweet perfume for many days. Some use the leares of sweet-scented Pelargoniums in place of Fern ironds, but the perfume of the Pelargonium leaves quite orerpowers that of the Violet blooms. Ferns, therefore, are best, and there are fer places in which a frond or two of them cannot be obtained.

\section{Orehids for Vases.}

Orchid flowers are most useful, either for hand bouquets, button-holes, or vases. It may be thought that they do not last long, but that is a mistake, as most of them remain fresh for a much longer time than many of our hardy garden flowers. Simplicity, in regard to plants selected for the decoration of rases is much to be commended, but to the nse of hardy flowers alone, when tender ones ean be had, I always object. There are few, I apprehend, who would not prefer a vase decorated with sprays of what are termed Bridal Orchids, intermixed with other suitable relieving subjects, whether tender or bardy, to one composed wholly of Harebells, Forget-me-nots, white Water Lilies, 
Veronicas, and Grasses. These may be within the reach of all, but those who have, or can afford to obtain, the rich, waxy, aud enchanting flowers of some of our Dendrobiums, Odontoglossums, Oncidiums, Phalænopsis, and others, by an elaborate system of arrangement can, in mnion with other suitable flowers, Fern fronds, and Grasses, prodnce a style of rase decoration unequalled by the most elegant composition of hardy flowers alone. If the rases are only required once, a great many flowers could be used that could not if they were recunired to stand for several nights; as for instance, Aërides, Saccolabiums, and some Dendrobinms-that would be of little service otherwise than wired-conld be effectively employed. These may sometimes be adrantageonsly nsed without wires; but, althongh graceful in the extreme when growing on the plants, they are apt, unless wired, to assume a clumsy appearance when used for furnishing table rases; and, if thus treated, they cannot get moisture to sustain their blooms in that desirable plump condition which they would retain if their stalks were inserted in water or damp sand.

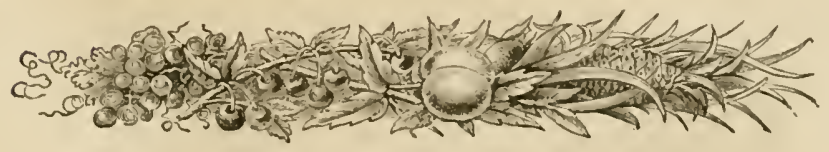


HAND BOUQUETS.

\section{CHAPTER XII.}

HAXD BOUQUETS-SPRAYS FOR THE HAIR.

\section{Fand Bouquets.}

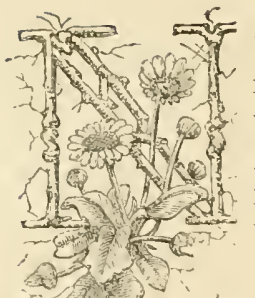

OTHING requires more taste or skill in its arrangement than a well-made hand bonquet. Is a rule, inexperienced persons employ as many flowers and Ferns to make one hand bonquet as a professional bouquet-maker would to make, with ease, three. The reasun of this is, in home-made bonquets (it I may be allowed to use the expresioni). the flowers are hardly ever momnted on wires, lut are left on their own stems. Doubtless, they remain longer fresh in that way; but who requires a bouqued to kecp fresh more than one erening? Each flower. or truss of blooms, as the case may be, which has a long stem, shonld have it cut off' with the exception of, at most, abont 2 inches; these stems shonld then be bound to a stub wire, the wire being boumd up nearly to the flower, so as to smplort the stem the whole way, otherwise the flower might be liable w break off above the stub. Before finishing off linding the stub and stem together-indecd, just after one or 
two twists of the binding wire have been given-a little damp Moss shonld be plaeed lound the stem of the flower, and then bound round with the binding wire. This keeps the flowers fresh the whole evening, and should be applied to every flower and Fern that is used in a bouquet; when making one, therefore, after the flowers have been wired, the next thing is to bind them to the stubs, as has just been deseribed. All being prepared snd ready to hand, the next thing is the making of the bouquet. Some seasons it is the fashion to have bouquets very large, while in others they are of mueh smaller dimensions; but the proper size may be determined by taking a peep into some first-elass florist's window. It is almost impossible to learn to make hand bouquets by means of printed directions; by far the best plan is to see one made. The way in which I myself tirst learned to make hand and button-hole bouquets was by watching how they were made in the shops in Covent Garden Market. My first attempts were very poor indeed, but I persevered, and many a prize have I taken for them sinee. All bouquets are finshed off with a flinge of Ferms romel the exge, the most suitable for this purpose being" Adiantum euneatum, a few fronds of which should stand up through the flowers in the bouquet. This tends to produce a light eflect, a point to which as mueh attention as possible should be paid. Bompuets are always finished ofl by a paper frill, the piereed work round the edge of which should be as handsome as possible when lace is not employed; papers are sold with lace attached, but 
these I do not approre of, as, when lace is used, it should be real and handsome, and bear looking into; that sold attached to the papers is only imitation and is much better dispensed with altogether. The only imitation lace which looks well for this purpose is Blonde, but in anj case the best plan in to tack on the lace to the paper jourself, when you ean select what kind you please. $A$ bow of ribbon and two long ends are often tied round the stems of bonquets, outside the paper or wicker shield, which keeps tamp from coming through and spoiling one's glores. If for a bride's bonquet, the bow and ends should be of pure white ribbon, satin or corded, according to taste. I myself prefer the latter, as being more elegant. For a ball or bridesmaid's bonunet, if of white and scarlet or blue and white, or any other colour selected with white. half of the bow and one end shonld be of white, and the other half shoukl mateh the colour in the houquet. I have seen this look partienlarly elegant where the bouquet was made of manve and white flowers. $\Lambda$ s a rule. I thiuk lace round the elge more suited for wedding hompuets than those to be used on other oceasions. For sending a bouquet a short distance, basket cases are sold. which prevent their being crushed. "Bouquets for the hand" (says "The Lady"s Paper") "should be mate of the choicest flowers, gracefully arranged; heary solid flowers or massive arrangements should be avoided as much as possible. Such bouquets are necessarily brought under the closest inspection of the eye, and should be composed of fluwers of delicate strueture 


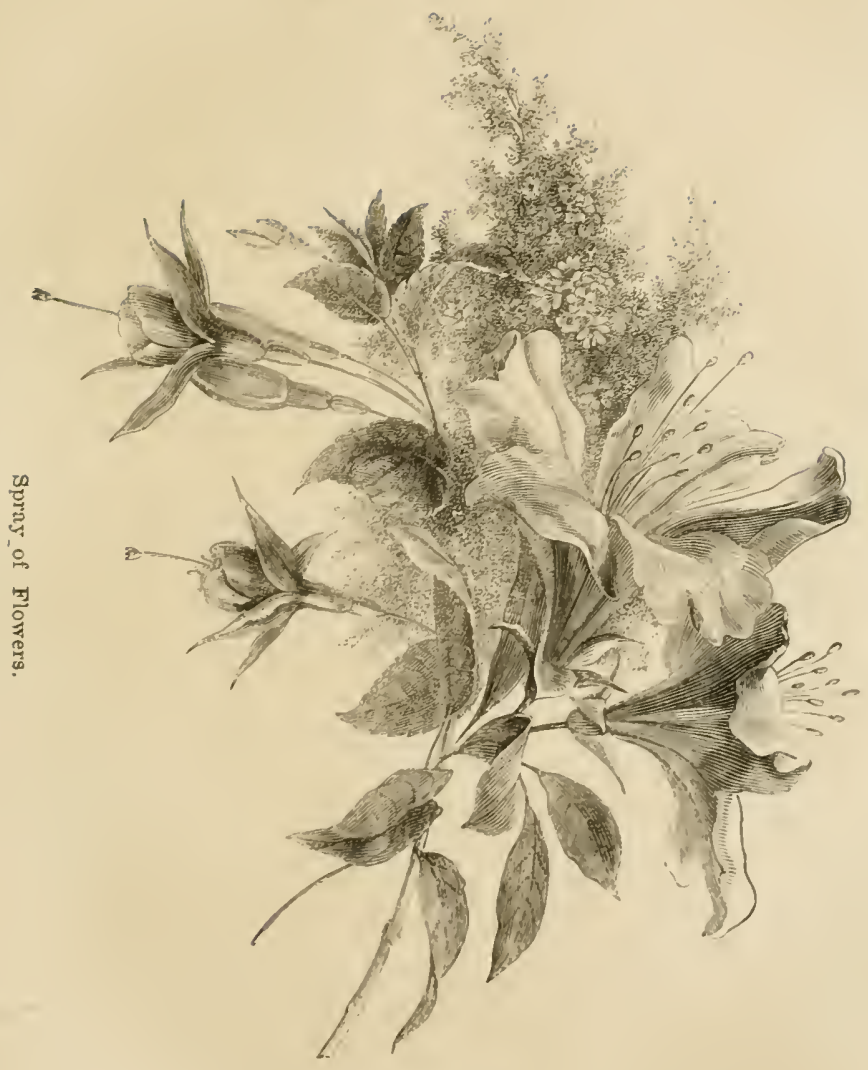



of great variety, and exquisite fragrance. The bouquet of the day (of immense size, and composed of solid flowers, scarcely relieved by foliage) is only suggestive of some cnormous rariegated or pied Fungus, hung with silk fringe, or put up in lace paper. When carried at evening entertaimments, they frequently appear to be a burden to their possessors. For successful effect in floral decorations much depends upon the judicious arrangement of colour; violent contrasts are also to be avoided, as is also the sameness produced by having too much of one colour. In producing harmonious contrasts of colours, it should be remembered that there are only three primary colours-red, blue, and yellow. From these arise what are called the binary or secondary colours, namely, orange composed of jellow and red; prople, composed of blue and red ; and green, composed of yellow and bluc. These form contrasting colons to the primary three with which they are in harmonious opposition, as the orange with blue, purple with yellow, and green with red. From the combination of these secondary colours arise three tertiary colours-olive, from purple and green; eitron, from green and orange ; and russet, from orange and purple. These tertiary colours harmonise with the primaries, as they stand in the relation of neutral tints to them, but are in harmonions opposition to the secondaries, from which thes are eombined. Red, blne, and yellow harmonise with each other, and they may be placed in juxtaposition, but purple should not be near red or blue, as it is composed of these two colours; for the same reason, orange should not he placel next 
to yellow or red, the rule being that no primary colour should be bronght into contact with a secondary colour of which itself is a component part; nor any sceondary colour brought into coutact with a tertiary colonr of which it is a component part. Another rule is, that the secondary and tertiary colonrs, and the nentral hues arising from combinations of the tertiaries, such as brown, maroon, pnec, slate, larender, \&c., should be used in the greatest quantitics, and the primary colom's used in smaller quantity for heightening the eflect. If you lack the proper shades for prodncing the necessary harmonies, and find that two colonrs do not harmonise well, separate them by a white flower. Again, always place the brightest colonx's in the cuntre of your design, and gradnally decrease the intensity of the tints as you approach the exterior; and aroid spottiness or patehiness by using as much as possible one prevailing colome." I always place in the centre of my bouqnets a Rose, Camellia, or some sneh flower. One of the prettiest bouquets I think I ever made was arranged as follows:-In the centre was a white Camellia, then white Azaleas, Stephanotis, Cardenias, Woodruff, and a rich mauve-shaded Cineraria, Lily of the Valley being spiked orer the whole, together with blooms of Dendrobium nobile and frouds of Adiantum crneatum, a fringe of the latter being formed round the edge. The whole was finished off by a handsome paper, and a bow and long ends of mave and white corded ribbon. 


\section{Sprays for the Hair.}

Elegant sprays of natural flowers may be mounted for this purpose with little trouble, and are far prettier than the artificial ones generally used. A little damp Mross or cotton-wool should be bound round their stems to keep them fresh, or it is a

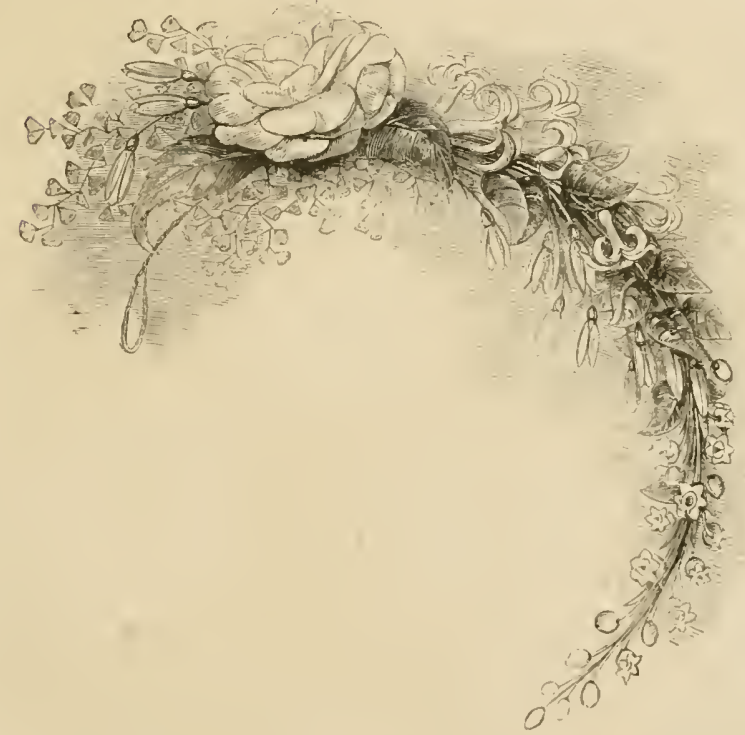

A Floral Wreath for the Hair.

good plan to insert the ends in a small glass tube, such as is sold for cut flowers (the sliarp hook having first been removed). This can be easily concealed amongst the braids of the hair, and in this manner flowers will keep fresh the whole erening. 


\section{CHAPTER XIII.}

BUTTON-HOLE BOUQUETS AND COAT_LLOWERS.

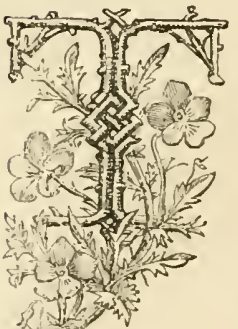

HERE are some who scem to think that there is no difference between a button-hole bouquet and a coat Hower; yet there is, and a rery great difference too, the flower being, as the word signifies, a single bloom, whereas a bonquet means a number of flowers arranged according to taste. Many opinions have been expressed as to the proper arrangement of cut flowers, but, with few exceptions, button-holo bouquets have becn excluded, probably, because being small, people have imagined that they must necessarily be easily made. No combination of flowers, howerer, requires to be put together with more taste, or with a lighter hand, than a properly made button-hole bonquet. Flowers selected for this purpose should always be good, particularly those for mounting singly, which should, in fact, be specimens of whaterer kind is chosen. Ferns, I always like to see in such bouquets, and also mingled with coat flowers, provided these are store or greenhouse kinds; but hardy flowers I like 
best mounted with their own foliage alone. Nearly all flowers for bouquets of any sort should be wired; indeed, many could not be used for that purpose at all were they not mounted on wire, as for example, the pips of white Hyacinths, which in winter are amongst the most useful flowers that we hare. There are, howerer, other ways of mounting flowers

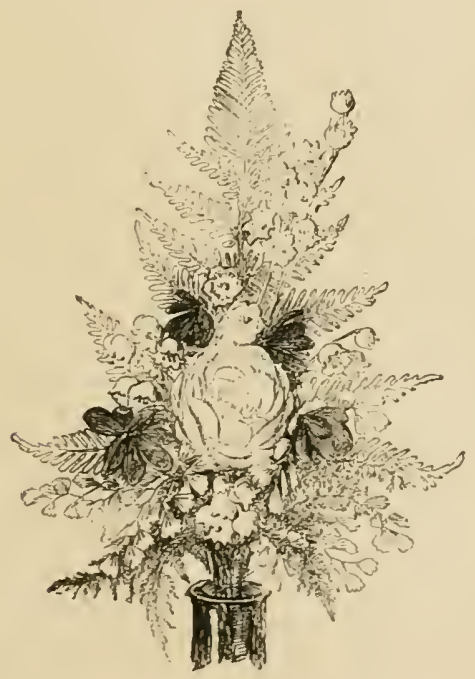

Button-hols Bou'juet.

besicles wiring them. Let ns take, for example, a Gardenia. The centre petals of this flower-indeed, all except the outside row-are very eren and lorely; but their beauty is somewhat marred by the outer ones, which look twisted. Now, to remedy this eril, and to make them look all eren, proceed as follows :Take a common Lanrel lcaf, and cut a piece out of it, 
about an inch or so square, with a pair of scissors; trim round the corners of this piece, so as to make it almost circular; then cut a cross in the middle, and down throngh that push the stem of the Gardenia, until the flower and the Laurel-leaf are pressed tightly together ; then hold it upside down, and throngh the stem, close to the leaf, pass a "stub" wire (which will keep the leaf in its place); bend the ends down and fasten them together with a little binding wire, so as to form a stem. The petals of the flowel can be then arranged so as to occups their proper places, and, the piece of Laurelleaf being pressed tightly to the flower, they will remain wherever they are placed. There is also another point to which I would wish to direct attention, and that is the fomclation of the button-hole bouquet, which is generally a piece of MIaiden-hail Fern; but that is not stiff enongh in itself to form a good support for the other flowers. To remedy this, the best plan is to back the Fern with a small Camellia-leaf, wired, which will kcep the whole bouquet firm and in shape. The following arrangement is that generally aclopted :-At the back is a spray of Fern; next, some long light flower, so as to form a kind of point or finish at the top; then a Camellia but or Rose, or some such flower, and then Maiden-hair Fern and whaterer other small flowers are at hand. A bouquet, to look well, may consist of a white Camellia bud, some sprays of Lily of the Valley, blue Squills, \&c., and Maiden-hair Fern. I once made one of a half-open white Camcllia bud, a spray of Hoteia (Spirna) japonica, and a fow 
pips of white Hyacinth, mixed with a little Maidenhair Fern, and many remarked that it was very light and elegant. That which took the first prize at the Royal Horticultural Society's Show at Birmingham, in 1872, was composed of a yellow Rose bud

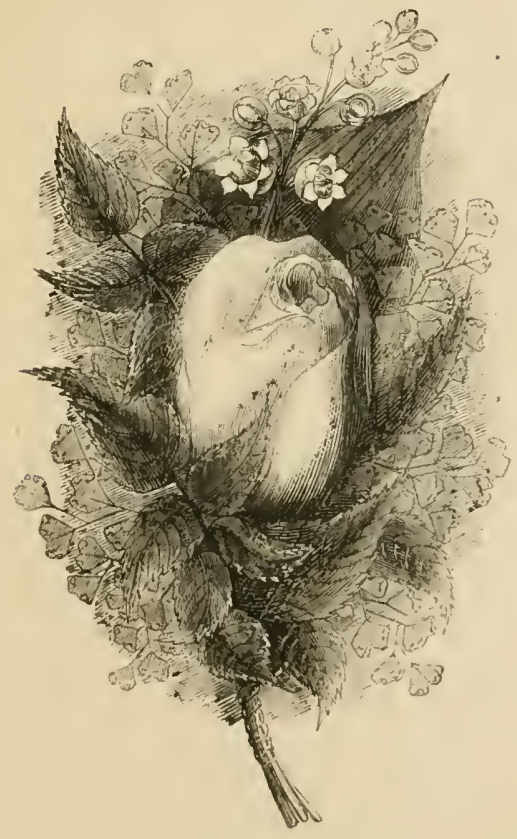

A Button-hole Bouquet for March.

assoeiated with blue Forget-me-not, a pip of Kalosanthes coceinea, and one of white Bouvardia. I have seen one male of Lily of the Valley, a blush-colonred Rose bud, and the same shade of Hyacinth pips, with a little Fern worked through 


\section{S4 BUTTON-HOLE BOUQUETS 1 ND COAT FLOWERS.}

it; this was a neat-looking little bouquet. Another. consisted of a spray of Lily of the Valley, a yellow Rose bnd, and a few pips of a rich purple Cineraria, which came ont well against the decp colour of the Maréchal Niel bud. I conld give descriptions of many others, but think that those which I have mentioned will suffice to show the best shape and style in which such bouquets should be made. Ferns used for' button-hole or, indecd, for any kind of bouquets, shoule be cut off plants that have been grown in a cool honse or that have, at all events, been well hardened of: otherwise, though they may look bright and fresh when ent, they shrivel up in a few homrs, when, of conrsc, their beauty is gone. In the case of Maiden-Lair': it is a good plan to cnt off the rers young points, $a$; with the exception of these, the other parts of the frond keep well. Another point that should be remembered, is always to keep the stems of the houprets as thin as possible, in order that they may easily pan-s throngh the coat, and correctly fit the little glass watertubes which are now so much worn, and which kcep both Ferns and flowers fiesh so much longer thas they otherwise would be. After the bouquets are male, many place their stems in water, to kecp them fresh; this I do not think a good plan, as, though the stems may be in the water, the Ferns are exposed to the air, and, thms ciremmstanced, they will not keep nearly so long fresh as if they wore shut up in some airtight box or drawer. Dealer's in bouquets hare number's of drawers lined with zine in which they keep theis. flowers, mounted or otherwise; those who have shops must have such appliances as these, but it is not in 
be expected that amateurs will be furnished with them. If I want to keep a coat flower from one day to another, I place it in a common tin box with a tightfitting lid, such as wafer biscuits are sold in, over the bottom of which is laid some wet Moss of the kind one gets in bundles at the flower shops, or finds in woods or on banks. I place the back of the boupret.

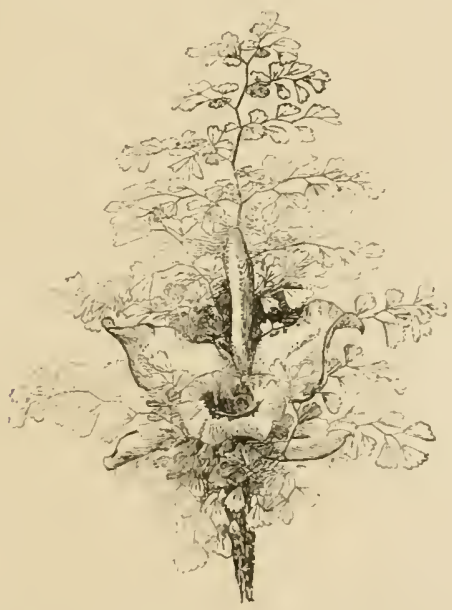

A Cuat Flower (Dendrobism and Maiden-hair).

next the Moss, and cover the stem over with some more wet Moss; I then sprinkle the flowers and Ferme well with water, and then shut down the lid, which is as ar-tight as possible, and, treated thus, flower's and Ferns will kecp fresh for days. If I want to send a bonquet by post, I put Moss enough in the hox to raise the bonquet, when laid on it, nearly level with the lid when shut down; and across the face of the 
flowers I lay a piece of cotton wool, which keeps them from rubbing against the lid.

Coat flowers I like associated with fronds of MIaidenhair Fern, that is if the flower is an indoor one; what, for instance, looks so elegant with a Gardenia as a bit of Adiantum cuneatum, the bright green spray of which sets off white blossoms of all kinds to much adrantage? The cuat flower to which was awarded the second prize at the Birmingham show before-mentioned, consisted of a small spray of red Combretum backed with a frond of Maiden-hair. There are numbers of flowers suitable for such an arrangement as this; but eare should be taken that such as are selected are good specimens of their respective kinds, and be a little shrouded in the Fern, as many coat flowers I have seen were quite spoiled by having only one spray of Fern, against which was laid the flower-the latter, under such circumstanees looking hard and stiff. Now, had there been another small piece to fill $u$, the space at the base, and a tiny bit drawn across the flower, the effect would have been much enhanced. This should always be done if the Hower is of a bright or glaring colour. I always like to see a Rose with a leaf belonging to itself behind it, and a few sprays of the young brown-coloured growth around it. Such an arrangement may seem easy to manage, but this is not the case, as the Rose leaf must be wired, and that is one of the most difficult of all things to do properly. Take a Rose leaf and lay it face downwards on a table. It will then represent a stem with two or three small leaflets on each side and one at the top. Down the centre of each of these small leares or 
leaflets is a comparatively thick mid-rib, with slighter ones branching off from it. Take a piece of fine wire and pass it through the leaf (always selecting the top leaflet first) under one of these slight ribs, and bring it up on the opposite side of the ribs. Subject two or three of the ribs to this operation, always keoping close to the centre rib; in fact, work is if you were sewing throngh the leaf, having the

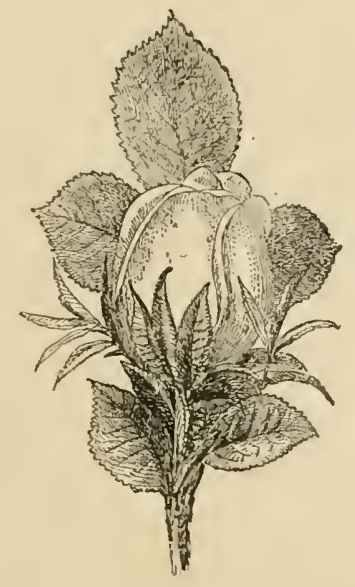

Coat Flower (small jellow Rose).

long stitehes, if I may so eall them, on the wrong side, and it will take great care and practice to kecp them from being seen on the right side. The wire should be cut off at the top, so as not to let it appear abore the point of the leif. The other part should be drawn down the long stem, and given a twist here and there; but take eare to keep the wire from being visible. The little side leaves shonld be treated 
in the same manner, the only difference being that the wire is cut off at each end, and not brought down the long stem like the top one. To do all this well takes some little time and trouble; but a Rose leaf if not mounted as just described, is liable to get ont of shape, and to hang down; if wired, howerer,

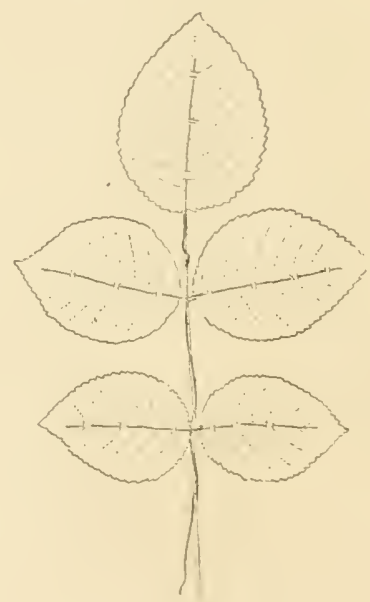

Wired Rose-leaf (back riew).

it keeps stiff and can be bent back and arranged according to fancy, just as one wonld adjust an artificial leaf.

It has lately become the fashion for ladies to wear small bonpuets in the front of their dresses or jackets. These are similar in erery way to those just described, except that they are at least a full size larger ; the directions, therefore, giren for mounting ordinary buttou-hole houquets, will suffice for those worn by ladies. 


\section{('IIATER NIY.}

FLORAL WREATHS AND CROSSES.

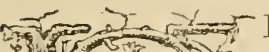

LACING floral offerings on the graves of teparted friends and relations. is, I an happy to say, becoming day by day more general. Some have a dislike to this custom; but, for my own part, I cannot see with what reason, as, after all, what can be more appropriate for the purpose than flowers? Such decorations generally consist cither of dried or fresh flowers. Of the latter I shall treat fully, but of the former merely remark that it is much better to buy them ready made than to make them, as one never can command snch a selection of dried fiowers and Grasses as can be obtained ready momted in the florists' shops in Corent Crarden. They can be bought, too, of erery size and forne, and at a cost to suit the means of every purchaser. Living flowers for the purpose of laying on tombs are nsually momnted in three forms, riz., wreaths, crosses, and flat bonquets. The colours selected should be of delicate lenes, as bright and glaring colours wonld be ruite ont of place for this purpose. For a young or unmarricel parson, pure white is gencrally selected, and for a 
married or elderly person, violet or manre is a pretty colour to introduce. The selection of flowers must of course depend on the season of the year. The fommdations of crosses are generally made of flat lintus, such as are used br plasterers in the formation of ccilings, or straight Hazel rods; those of wreaths, of wire; and for flat bouquets, branches of Yew are most frequently emplored. In these different derices a quantity of Wood Moss is used, particularly where they take the form of a wreath or cross, for, as well as prescring the freshness of the flowers, it also forms the foundation or mat of green into which the flowers are worked or bedded, if I may be allowed to make use of the term; and, on account of occupying so prominent a position, only that which is perfectly green and fresh-looking should be employel. All Moss to he used in the construction of crosses shonld be well washed in water, so as to remore all particles of decayed leares and chips of sticks which are always to be found throngh Wrood Moss. After it has hecn passed throngh the water till quite free from such rubbish, the moisture slionld be gently squeczed from it, except enough to keep the flowers fresh, withont leaving a damp mark where the decoration rests. When this luas been done the MIoss should be pieked orel, and all the stems placed in one direction; for, the points of this Moss heing of a lighter and prettier. tint than the other portions, evemness of colom in the fomdation is obtained by placing them in this mamer. The formation of a wreath is rery similar, except that to keep the circle perfect requires more practice than the straight lines of a closs. Haring some strong 
wire, the Moss, the flowers, and a reel of fine binding wire ready prepared, the formation, say, of a wreath, may be thus proceeded with. First, make a piece of the strong wire into whatever sized circle is required; then take some of the Moss and bind it with the wire off the recl on to the stouter wire, catching the stems of the Moss about half way down with the former; keep the Moss as even as possible, and make it a perfect bank or ribbon of green of a wilth in proportion to the size of the circle. Into the Moss, as you go along, the flowers should be worked, the Moss being pressed up close to them, so as to give them moisture, and also to keep them firmly in their places. The most difficult part of the wreath to complete is where the stems of the Moss meet in the finishing of the circle. When it comes to the junction, the Moss must be worked in both ways till the space is filled by one finishing tuft. In a cross the end is the most difficult part, and this must be finished in a similar manner. In flat bonquets, much Moss is not usecl, at least not in proportion to the amount employed in crosses, \&c., all that is recuired here being just sufficient to keep the flowers fresh mounted on twigs or stub wires as in a hand bonquet. MTost bouquets of this kind are made of an oval or pointed form, the centre being composed of some large-sized flower; Arum blooms are farourites for this purpose. $\Lambda$ s to the sclection of flowers, as I before remarked, they must be in accordance with the scason of the rear, and I think the best guide I can give for this purpose is a description of a few decorations I have made myself at different seasons of the year. In Norember, 
I once made a wreath of large dimensions, composed of the following flowers:- White Camellias, Encharis, Bouvardias, Roman Hyacinths, Neapolitan Violets, and Ferns of the following varieties, Adiantum cuncatum, A. marinum, and A. Trichomanes. In December I made a cross abont 18 inches high, composed of white Camellias and Roman Hracinths onl 5 ; also, at the same time, a flat bourquet, in which the following were employed:- White Azaleas. Bonvardias, Encharis, Roman Hyacinths, Heaths, and a large-sized Arum bloom, with Fern fronds interspersed through the whole. Late in February, I made a large-sized cross, about is feet in length, of white Camellias, Snowdrops, pips of a lavender-coloured Hyacinth, and Fern fronds; and, at the same time, two flat bougnets of Tiolets and Primroses. During the summer months such flowers as Lilies, white Rose bnds, Lily of the Valler. \&c., conld be substituted for the abore, which I have merely entumerated on acconnt of having used them myself, and because their names indicate the style of flowers which shonld be mployed when obtainable. Box and similar shrubs are much used in the construction of wreaths and crosses sold by the florists, on account, I suppose, of their being more quickly made with such materials; but I myself much prefer the fresh green of the Wood Moss. In the same manner floral ornaments can be finshioned. such as are so much used at Christmas, laster, and Whitsuntide in our churehes. The large wreath which I have described would be well adapted to the decoration of a font, or, perhaps, it wonld be more suitable for that purpose if it were male of white flowers; lowerer. the plan and mode of manufacture would be 
just the same in ciller case. The cross and flat bouquet would do well also for the decoration of an altar. In the construction of crosses or wreaths too many large flowers, such as Camellias, should not be used, as they tend to give the decoration a flat and heavy look, which should be carefully aroided. It is the fact of too many flowers of this kind being employed that makes these styles of arrangement, when exhibited in the florists' windows, appear out of keeping with their hand or button-hole bonquets, as regards lightness, but there is no reason why this should be so. Lightness is the great perfection of art in all floral arrangement, and why should it not be carried out in this branch as in any other, save that the more Camellias are employed, the more is charged for the ornament? I have seen wreaths exhibited in Covent Garden Market made solely of white Camellias, packed as close as they could be; the effect was heary and bad, and, for about half the cost a much more effective arrangement could be madc with flowers of a lighter growth, only a few Camellias being employed in its construction.

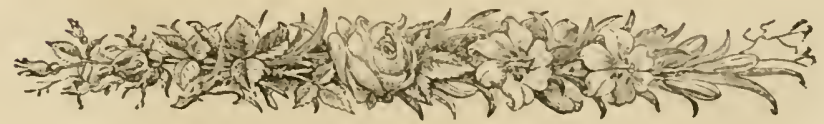




\section{CHAPTER XT.}

ARRANGEMENT ON FLUWERS FOR FACH MONTH.

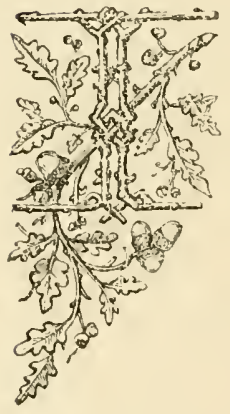

SHALL here give deseriptions of a few rases llorally dressed for eacli month, selecting in form those most often met with in every houschold, and illustrated in some of the carlier. cliapters of this book.

\section{January.}

\section{MARCHAIN YASE.}

Lower Tazza :-Arums, Poinsettias, Primulas, Heaths. Maiden-hair, and round the elge mixed varieties of Ferns.

Upper Tazza :-Scarlet Bouvardia, double white Primulas, Heaths, Maiden-hair, and round the elge drooping frouds of Pteris serrulata.

Trumpet :-Scarlet Epaeris, Roman Hyacintlss, Maiden-hair, and Lygodium seandens.

VASE WITI CURVED TRUMPETS.

Rising ont of 'Three Curved Trumpets :- Arum blooms, pink Geraninms, Heaths, and Maiden-hair. 
Top Trumpet:-Pink and white Heaths, Maiden-hair, and long sprays of Lygodium seandens twined amongst the trumpets.

\section{TRUMPET VASE.}

Tazza :-Stephanotis, Poinsettias, white Cyclamen, and Maiden-hair.

Trumpet :- Cyclamen, Mignonette, searlet Pelargoniums, and Maiden-hair.

\section{February.}

\section{MARCHAIN VASE.}

Lower Tazza :- Stcphanotis, purple Cinerarias, Mignonette, white Primulas, Roman Hyacinths, and Maiden-hair ; round the edge mixed Ferns with some of the golden varieties interspersed through them.

Upper Tazza :- Gardenias, purple Cinerarias, Cjclamen, Maiden-hair, and, drooping round the edge, sprnys of Selaginella denticulata.

Trumpet :- Purple and white Cyclamen, white Heaths, Maiden-hair, and Lygodim seandens.

\section{VASE WITII CURVED TRUMPETS.}

Rising out of Curved Branches :- Blooms of Poinsettias, double white Primulas, searlet Begonias, and Maiden-hair.

Top Trumpet :-Searlet Begonias, Roman Hyacinths, Maiden-hair, and Lygodium seandens.

TRUMPET VASE.

Tazza :-White Camellias, Violets, Roman Haacinths, 
and Maiden-hair; round the edge a fringe of Pteris serrulata.

Trumpet:-Roman Hyaciuths, and Maiden-hair.

\section{March.}

\section{MARCIIAIN TASE.}

Lower Tazza :-Stephanotis, pink Pelargoniums, double white Primulas, pirik Heaths, Cyperns alternifolins, and Maiden-hair ; round the edge fronds of Pteris serrulata and Pteris cretica albo-lineata.

Upper Tazza:-White Carnations, pink Azaleas, Lily of the Valley, and Maiden-hair, fronds of the same drooping round the edge.

Trumpet :- Lily of the Valley, pink Heaths, and three sprays of Solomon's Seal, a few fronds of Maiden-hair being arranged ronnd the mouth.

VASE WITH CURYED TRUMPETS.

In each of the Curved Branches : - $A$ spray of Solomon's Seal, some deep blue Cinerarias, Deutzia gracilis, and Maiden-hair.

In Top Trumpet:--Three sprays of Solomou's Seal, some Lily of the Valley, a few sprays of Cineraria, Maiden-hair, and Lrgodium scandens.

\section{TRUMPET V.ASE.}

Tazza :-Yellow Roses, Nenpolitan Violets, Lily of the Valley, and Maiden-hair ; round the edge, mixed varieties.

Trumpet:- Lily of the Valley, Cyelamen, and Maiden-hair. 


\section{April.}

\section{MARCHAIN VASE.}

Lower Tazza :-Deep pink and white Azaleas, Maiden-hair, and round the edge Pteris serrulata.

Upper Tazza :--Pink Azaleas of a lighter shade than those employed below, Spirxa, and Maiden-hair.

Trumpet :-Solomon's Seal, Dielytra, and Ferns.

VASE WITH CLRVED TRUMPETS.

Rising out of Trumpets :-Arums, Lily of the Valley, Mignonette, blue Forget-me-nots, and Maidenhair.

In Top Trumpet :--Spiræea, Solomon's Seal, Forgetme-nots, Maideu-hair, and Lygodium seandens.

\section{TRUMPET VASE.}

Tazza :-Yellow Roses, Orehids, Stephanotis, and Maiden-hair.

In Trumpet :- Blooms of Dendrobium nobile, Woodruff, Lily of the Valley, and Maiden-hair.

\section{May.}

\section{MARCHAIN VASE.}

Lower Tazza :-Yellow and pink Roses, Stephanotis, pink Rhodanthe, Spirea, pink Ericas, blue Forget-menots, Lily of the Valley, and Maiden-hair ; round the edge Pteris serrulata.

Upper Tazza :-Eucharis amazoniea, pink Pelargouiums, white Rhodanthe, Forget-me-nots, Lily of 
the Valley, and Maiden-Lair, with long fronds of the latter drooping round the edge.

Trumpet:- White and pink Rhodanthe, Lily of the Valley, Ixia viridiflora, Spiræa, Maiden-hair, and some very long sprays of Lygodium scandens.

VASE WITH CURVED TRUMPETS.

The Curved Branches :-Yellow Roses, Lily of the Valley, long sprays of Bougainvillea, and Maiden-hair.

The Top Trumpet:-The same, with the addition of Lygodium seandens.

\section{TRUMPET VASE.}

Tazza :-Encharis amazonica, blue Nemophila, Lily of the Valley, and Mraiden-hair ; round the edge Brake Fern.

Trumpet:-Spiraa, Lily of the Valley, blne Forgetme-not, and Maiden-hair.

\section{June.}

\section{MARCHAIN VASE.}

Lower Tazza:- Yellow Roses, Bougainvillea, Spirar, Brown Rose tips, and Maiden-hair ; twined up the glass stem a spray of Japan Honeysuckle, and round the edge of tazza mixed varieties of ferus, some golden ones amongst them.

Upper Tazza :- Blooms of Encharis amazonica, Dendrobium nobile, Lily of the Valley, and Maidenhair ; round the edge long drooping sprays of Selaginella denticulata.

Trumpet :-White Rhodanthe, Lily of the Valley, 
a spray of Dendrobium nobile, Maiden-hair, and Lrgodium scandens.

\section{YASE WITH CURVED TRUMPETS.}

In Curved Branches : - Blooms of Eucharis amazonica, white Rhodanthe, white Sweet Pea, blue Cornflowers, Maiden-hair, and wild Grasses.

In Top Trumpet:-The same, with the addition of Lygodium seandens.

\section{TRUMIPET VASE.}

Tazza : - White Water Lilies, pink Christine Creranium, white and pink Rhodanthe, Maiden-hair, and wild Grasses; round the edge fronds of the common Biake Ferri.

Trumpet:- Pink Geraniums, white and pink Rhodanthe. Maiden-hair, and wild Grasses and Oats.

\section{July. \\ MARCHAIX TASE.}

Lower Tazza :- White Water Lilies, Kalosanthes coccinea, white Rhodanthe, ILaiden-hair, and wild Grasses; round the erlge fronds of Pteris serrulata.

Upper Tazza : - Blooms of Tueharis amazonica, searlet Pelargoninms (the same shade as the Kalosanthes), white Rhodanthe, Maiden-hair, and Grasses ; round the extge drooping fronds of Mraidenhair.

Trumpet :-Sicarlet Pelargoniums, white Rhodanthe, wild Grasses and Uats, Mraiden - hair and Ljgodium scandons. 


\section{VASE WITH CURVED TRUMIPETS.}

Rising ont of Curved Branches:-Blooms of Lilinm longifolium, pirk fancy Pelargoninms, white Rhodanthe, and Maiden-hair.

Top Trumpet :- White and pink Rhodanthe, and wild Grasses.

\section{TRUMPET VASE.}

Tazza : - Water Lilies, blue Forget-me-nots. Rhodanthe, and wild Grasses ; round the edge frond: of the common Brake Fern.

Trumpet:- Blue Forget-me-nots, white Rhodauthe, and wild Grasses.

\section{August.}

IIARCLAIN VASE.

Lower Tazza : - White China Asters. blne Agapanthus, white Clematis (wild or sweet-scented), Grasses, and Mraiden-lrair ; round the edge Brake l'ern.

Upper Tazza :- Clematis and blue Agapanthus, Crasses, aud round the edge mixed rarieties of Ferns arranged to droop gracefully.

Trumpet:-Blue and white Agapantlus, Maiden-Lair. and Grasses.

VASE WITII CURVED BRANCIES.

Curved Branches :- Blooms of Tilinm auratmm. Kalosanthes coccinea, yellow Calccolaria, blue Cormflower, white sweet Pea, Grasses, and Maiden-hair. 
Top Trumpet:- The same, with the addition of Lygodium scandens.

\section{TRUMPET VASE.}

Tazza : - White Clematis, Pink Pelargoniums, Grasses, and Maiden-hair ; round the edge mixed varieties of Ferns.

Trumpet:-Long sprays of Clematis, Pelargoniums. Ferns, and Grasses.

\section{Septamber.}

MARCHAIN VASE.

Lower Tazza :-Pink and white China Aster, blue Agapanthus, white Clematis, Maiden-hair, and Grasses; round the edge Pteris serrulata, and some silver varieties.

Upper Tazza :- Whitc Clematis, blne Agrapanthus. pink Heaths, Ferns, and Grasses; round the edge long fronds of Maiden-hair.

Trumpet:-White and pink Heaths, white and blue Agapanthus, Clematis, and Grasses.

\section{VASE WITH CURVED TRUMPETS.}

Rising out of Trumpets :-Blooms of white Lilium lancifolinm, blue Agapanthus, Pink Begonias, blooms of the Arbutus, Grasses, and Ferns.

Top Trumpet:-The same flowers, with the addition of sprays of Passion-flowcr.

\section{TRUMPET VASE.}

Tazza :- Iollow Rose, blue Agapanthus, Iresine, and 
Maiden-hair ; round the edge fronds of Asplenium viviparum, and Pteris cretica albo-linenta.

\section{October.}

\section{MARCHAIN VASE.}

Lower Tazza :- White Aster's, donble scarlet Pelargoniums, Clematis, and Maiden-hnir' ; round the edge fronds of the Brake Fern.

Upper Tazza:-Scarlet Pelargoniums, Clematis, white sweet Pea, and Grasses.

Trumpet:- Searlet Salrias, Clematis, Grasses, and Maiden-hair.

VASE WITH CURTED TRUMPETS.

Rising out of Curred Branches:- Pink Jeaths, Encharis amazonica. pink Begronias, and Mariden-hair.

In Trumpet: - Pink Heaths, Regonias, Clematis, Grasses, and Ferns.

\section{TRUMPET V.LSE.}

Tazza :- White Campanula, blue Agapanthus, Ferns, and Grasses.

Trumpet:- Filled to matel.

November.

MARCHAIN VASE.

Lower Tazza : - White Primulas, searlet Pelargoniums, Maiden-hain' and Ginsser.

Upper Tazza : - White C'amellins, senrlet P'elargoniums, and Maiden-hair; round the edge fronds of the same. 
Trumpet :-Scarlet Begonias, double white Primulas, Maiden-hair, Lygodium scandens, and a few Grasses.

VASE WITH CERVED TRUIPETS.

Curved Branches :-Blooms of Eucharis amazonica, double white Primulas, pink Gloxinias, and Maidenhair.

Top Trumpet:-Primulas, Gloxinias, pink Begonias, Maiden-hair, and Lygodium scandens.

\section{TRUMPET YASE.}

Tazza :- Blooms of Eucharis amazonica, purple Gloxinias, and Roman Hyacinths; round the edge and through the flowers, Maiden-hair.

Trumpet :- Gloxinias, Romau Hyacinths, and Maiden-hair.

\section{December.}

\section{MARCHAIN TASE.}

Lower Tazza :-White Camellias, Poinsettias, Roman Hyacinths, Primulas, and Maiden-hair, and round the edge mixed varieties of Ferns.

Upper Tazza : - Eucharis amazonica, scarlet Bouvardias, Roman Hyacinths, and Maiden-hair ; round the edge, arranged so as to droop over, long fronds of Maiden-hair, with blooms of Lapageria rosea through them.

In the trumpet :-Roman Hracinths, scarlet Bourardia, and Maiden-hair.

VASE WITH CLRVED TRUMPETS.

Curved Branches :- Arums, scarlet Bouvardia, 
104 ARRANGEMENT OF FLOWERS FOR FACH MONTH.

Roman Hyacinths, blooms of Lapageria rosea, and Maiden-hair.

Top Trumpet:-Roman Hyacinths, scarlet Geraniums, and Maiden-hair.

\section{TRUMPET VASE.}

Tazza : - Primulas, Roman Hyacinths, pink Geraniums, and Maiden-hair; round the edge fronds of hardy Ferns.

Trumpet:-Roman Hyacintlss, pink Geraniums, and Maiden-hair.

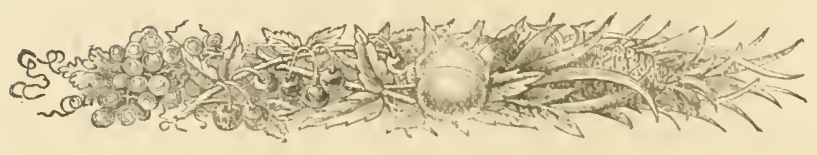




\section{CHAPTER XVI.}

FLOWERS IN BLOOM EACH MONTH.

January, February, March, and April.

SCARLET.

Arbutus,

Holly Berries,

Geranium,

Poinsettia, Tulip.

CRIMSON AND PINK.

Azalca,

Camellia,

Chinese Primrose,

Cineraria,

Dielytra,

Heath,

Tulip.

BLUE.

Cineraria,

Nemophila,

Scilla.
PURPLE AND MALYE.

Cineraria,

Crocus,

Pansy,

Evening Primro:e,

Violet,

Wistaria,

Cyclamen.

YELLOW AND ORATGLE.

Azalea,

Crocus,

Genesta,

Primrose,

Tulip.

WiIte.

Camellia,

Chinese Primrose,

Christmas Rose,

Crocus, 
WHITE.

Cyclamen,

Deutzia,

Heath,

Hyacinth,

Lilac,

Lily of the Valley,

Narcissus,

Snowdrop,

Tulip.
FOLIAGE.

Geranium leaves,

Iv

Myrtle,

Fern,

Greenhonse foliage and creepers,

Store foliage

and crecpers.

May, June, July, and August.

SCARLET.

Bonvardia,

Anemoue,

Cactus,

Carnation,

Euphorbia,

Geranimm,

Ixin,

Lobelia cardinalis,

Salvin,

Tulip,

Verbena.

CRINISON AND PINK.

Azalen,

Cactus,

Camcllia,

Carnation,

Crassula,
CRIMSON AND PINK.

Fuchsia,

Creranium,

Gloxinia,

Heath,

Lilium lancifolium,

Pink,

Rhododendron,

Rose,

Sweet Pca,

Verbena.

BLUE.

$\Lambda$ gapanthus, Ageratum, Camp̧anula, Cornflower, Clematis, Delphinium, 
BLUE.

Forget-me-not,

Iris,

Lupin,

Nemophila,

Salvia.

PURPLE AND MAUVE.

Clematis,

Gloxinia,

Heartsease,

Lilac,

Orchis,

Petunia,

Sweet Pea,

Verbena.

WHITE.

Agapanthus,

Bouvardia,

Campanula,

Clematis,

"sweet-

scented,

Carnation,

Eucharis amazonica,

Forget-me-not,

Gardenia,

Heath,

Iris,

Lilium lancifolium,
WHITE.

Lily,

Lily of the Valley,

Lilac,

Orchis,

Narcissus,

Pink,

Rose,

Stephanotis,

Sweet Pea,

Syringa,

Verbena,

Water Lily,

Woodruff.

YELLOW.

Azalea,

Calceolaria,

Heath,

Jonquil,

Laburnum,

Orchis.

FOLIAGE.

Asparagus,

Begonia,

Caladium,

Cissus discolor,

Cobæa,

Coleus,

Forns and Lyco-

podiums, 
FOLIAGE.

Geranium,

Gesnera,

Hop,

Ice Plant,

Iry,

Maple,

Maize,
FOLIAGE。

Mignonette, M Jrtle,

Passion Flower,

Rose, young shoots,

Virginian Creeper,

Veronica, \&e., \&c.,

September, October, November, and December.

Arbutus,

- China Aster,

Chrysanthemum,
Dahlia, Gladiolus, Holyhoek.

This list is only intended as a rough guide, and nothing more. It would be impossible to enumerate all the flowers available in their respective season., and many, therefore, have been omitted. Besides, many that $I$ have mentioned as being in season in June and July-for example, the Rose-ean be obtained as forced flowers in Covent Garden Market long before those ont of doors come into bloom.

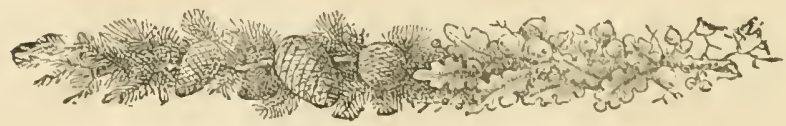




\title{
CHAPTER XVII.
}

\author{
POT PLANTS IN ROOMS.
}

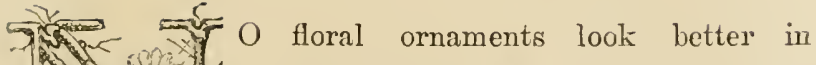
Volver sitting-rooms than well-grown pot 3 olants, which have a great advantage II 1 (a) over cut flowers, inasmuch as they last longer in perfection, To tornspeople who have no gardens or glasshouses they are a real boon. Plants of all kinds, suitable for rooms, may be obtained in Corent Garden Narket, but, being, as a rule, reared tenderly in heat, they soon drop their blossoms when placed in their new rquarters. Aroid, therefore, plants brought direet to the market from a stove, or other house, much heated, and select such as have been brought up hardily, for no care will keep plants just out of a hothouse fresh or healthy-looking; the sudden change from heat to cold is eertain to make them flag. Having made sure that the right kinds of plants have been obtained, the next thing to be considered is, how the pots are to be concealed, as eommon garden pots are anything but ornamental. To remedy this evil, some set their pots in mper corers 
of different colours; others slip them into china pots. Rustic covers are also sold for hiding pots, while some eonceal them in the following manner: -A bundle of common Brake Fern is obtained, and the ends of the Fern fronds, ent in a slanting direction with a sharp knife, are insertcd in the soil with which the pot is filled, close to the rim, over which they are broken, so as to make them droop and hide the pot. For those who may not like this plan, and who will not go to the expense

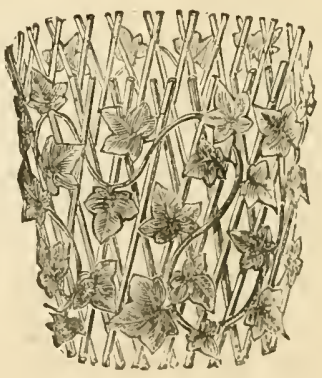

Ornamental Pot-cover.

of china pots, a new improvement on the plain rustic expanding covers has lately been introduced, differing only from the old style in being ornamented with artificial Ivy, Vine, and other varicties of leaves which tend to give it a pretty appearance. Such pot-covers are well suited for plants in halls, or for ordinary use; but, for the dining-room and dinnertable, they should be of ehina, than which nothing is more effective. Some are made to stand on a table or bracket, painted in pairs to match; while 
others are mounted singly, on tripods of iron or wood. I have seen a design made of bronze to stand on a table; at its base were two china pots,

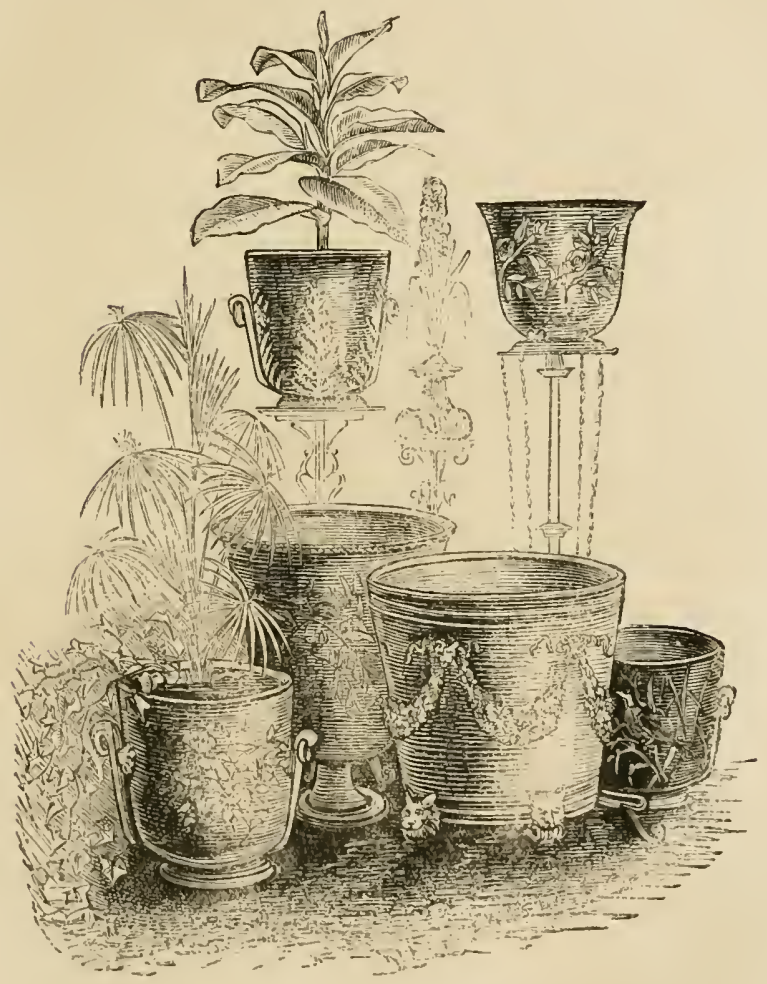

Oruamental Flower-pots.

and raised about a foot or 18 inches, supported on a pillar of ornamental bronze, was another china pot. Being of bronze this stand was probably intended for the hall or dining-room, as I also saw several 
in ormolu, which would look lighter for drawingroom decoration. After plants have been placed in such ornamental pots or covers, the surface of the soil in which they are growing should be covered either with silcer sand or Wood Moss: if with the

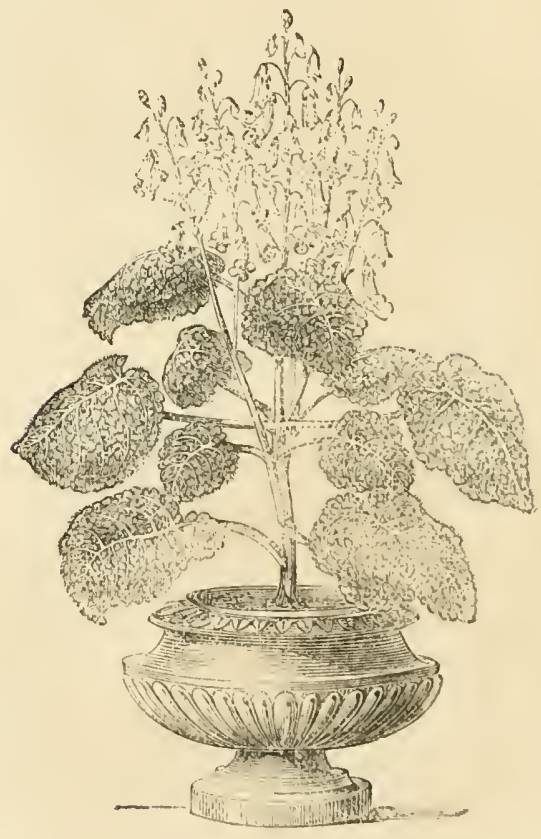

Gesnera refulgens.

latter, and any of the plants happen to be Ferns, eare should be taken that the Moss does not eorer any of the young fronds. All plants should be removed to the eonservatory at night, if there be one; if not, into some room in which no gas has 
been burning. It is bad enough to kecp plants in a gas-lighted room for any length of time, but, after the gas is turned out, they should be remored, as the atmosphere, which is still charged with its fumes

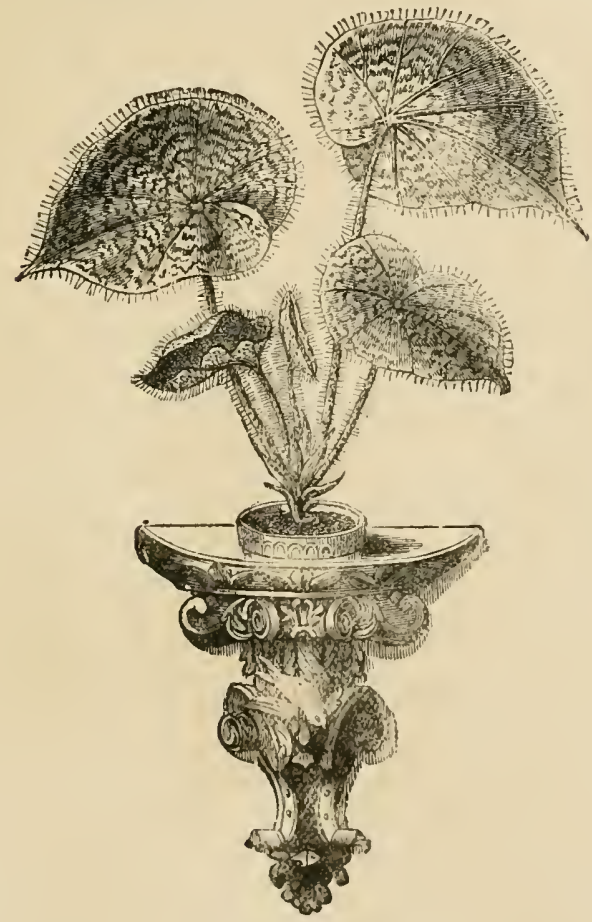

Plant Brackot.

sadly injures them. In the morning water should be given them if they require it. Palms and other fiue-foliaged plants should hare their leaves sponged over with water every morning, and the flowers of Pelargouiums and similar plants may be mado to 
last for a long time if a drop of gum, such as is uned for cut flowers, is dropped into the centre of each bloom. By observing these little items, plants may be kept in good health just double the time they otherwise could be. Plants look well set on brackets, though this style of decoration is not often resorted to; I am certain, however, that if tricd, a good effect would be the result. Brackets may be purchased made of different materials; some are of terra cotta, other:s of china; some are made of wrought iron, painted to imitate bronze, others of Swiss carved wood, and others, again, are gilded. Some brackets are fixed flat against the wall, others are made to fit into corners. Those made with a hollow, into which the pot can be dropped out of sight, are much the best for upright-growing plants; but where an Iry-leaved Pelargonium, or any drooping plant, is employed, it does not matter, as the foliage of the plant, if a good specimen, quite conceals the pot from view. One of the most effective plants for this style of decoration is a large and handsome specimen of Asplenium flabellifolium (Fan-leared Spleenwort). No one who has not seen a plant of this no placed can have any idea of its beauty.

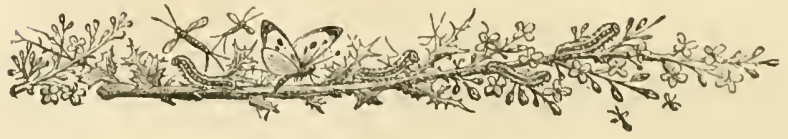




\section{UHAPTER XVIII.}

WINDOW GARDENING-HANGING BASKETS-FERN CASES-STANDS OF PLANTS.

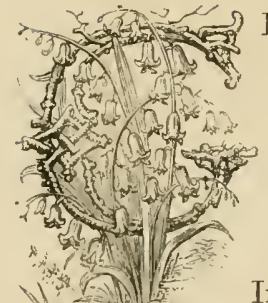

ROIVING plants for the decoration of windows seems to be coming more into fashion every day. Some have them placed inside, and others outside, their windows; but, as this little work is confined strictly to Indoor Floral Decorations, I shall not touch upon those grown ont of doors. Indoor Window Gardening comprises several styles. These are-Hanging Baskets, Wardian Fern Cases, Ornamental Stands of Pot Plants, \&e. As I intend to treat of each style separately, I shall begin first with

\section{Hanging Baskets.}

Hanging baskets, tastefully filled with plants, are seldom to be met with; yet more charming ornaments for a room could not be found. Baskets of living plants may easily be had in perfection, and of these I select such kinds as will stand in rooms. As regards the baskets themsclves, I like to see the wirework painted dark green. Some paint it with bright 
colours, which quite spoil the effect of the flowers, which should be sufficiently brilliant in hue to require no assistance from paint. Inside the wire-work put a thick layer of green Moss, so as to prevent the soil from dropping through; over this put some broken crocks, and then fill up with whatever compost is best

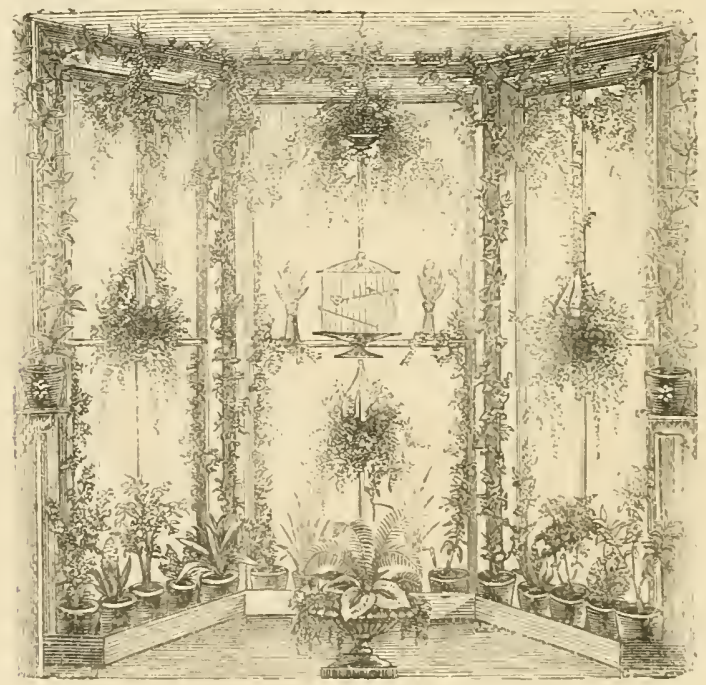

Open Bay Window Garden.

suited to the requirements of the plants with which the baskets are to be filled. For summer decoration there are numberless plants that can be grown in baskets; but, for winter blooming, nothing is better, or looks more showy than Rollisson's Unique Geranium or Scarlet Tropacolum, both of which will continue in flower all through the winter, and droop 


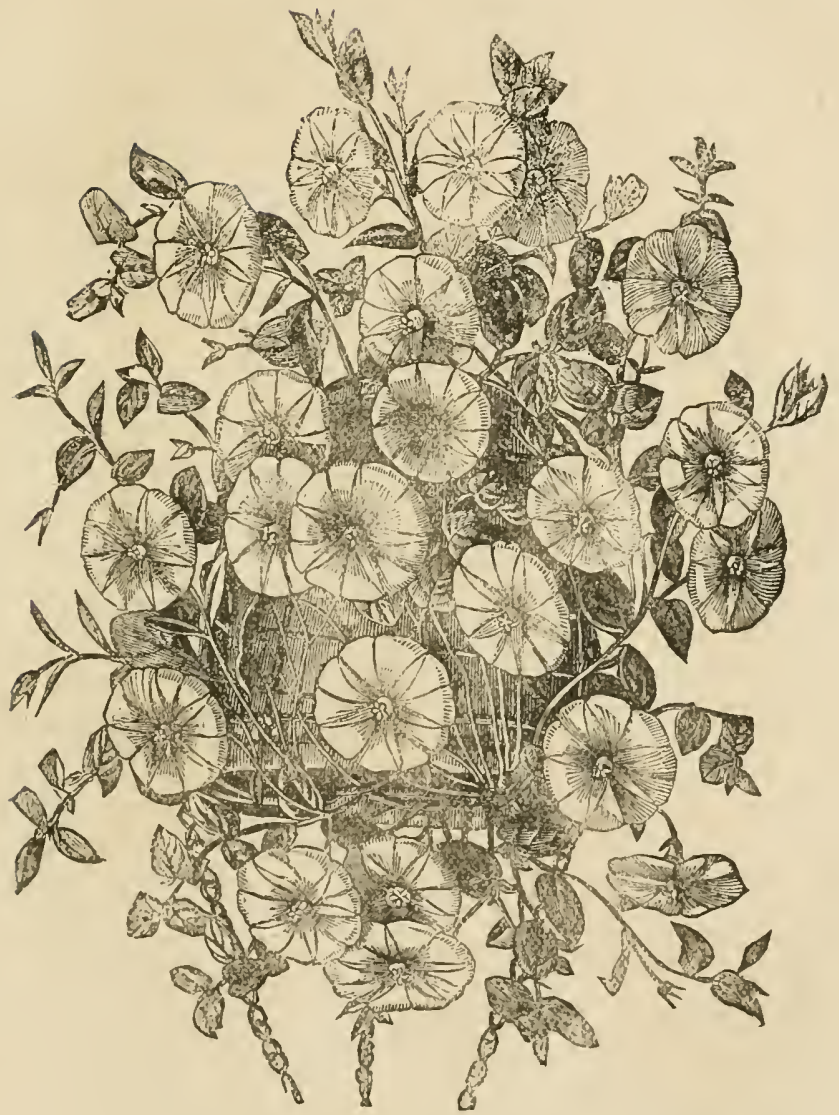

Bine Conrolvulus. 
down gracefully all round the basket. A basket, indeed, never looks well unless it is furnished with some drooping plant round the.edge, as, for instance,

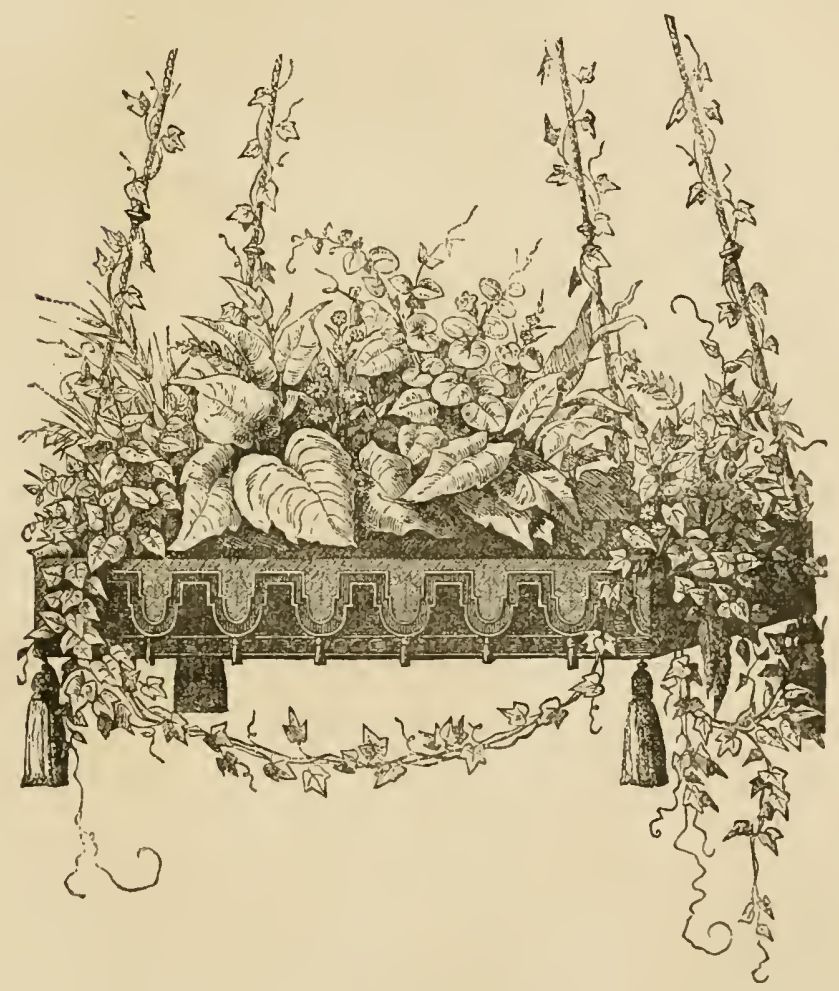

Suspended Window Basket.

with the variegated Iry-leared Pelargonium, called L'Elégante; while, in the eentre, should be a well. grown plant of Fuchsia Mrs. Marshall. Pretty baskets may also be made of silver variegated 
Geranium Lady Plymouth and bright blue Lobelia, or of blue Convolvulus, with Christine Geranium in the centre ; in fact, any flower that suits, and is put in with good taste, will look well. For large baskets, suited for lobbies, mixed foliage plants, such as variegated Sedums, Eeheverias, Iresines, and Centaureas, have an effective appearance. A windowbox made of wood, and lined round with zinc, suspended by four eords or wires, up which ean be trained creepers, also makes a pretty room ornament. The great point, as regards keeping plants in baskets or boxes fresh and in good health, is to give them plenty of water during the growing season, but more sparingly in winter, and to keep the leaves clean. If baskets are hung high there should be some means of lowering them, as it is troublesome getting up to them every morning with steps. If the baskets are small, the best way is to carry them away and water them outside; but in the case of large baskets this cannot be done, so a tea-tray or something of the kind should be placed under them to eatch the drip.

\section{Fern Cases.}

Ferns are plants which give little trouble, yet they are seldom to be found in sitting-rooms. For those who do not possess a large Fernery there can be no more interesting or pleasing occupation than attending to and watehing the growth of these plants in their miniature house. Wardian eases may be purchased at a small or large outlay, aceording to size or ornamentation, but plain cases are quite as suitable 


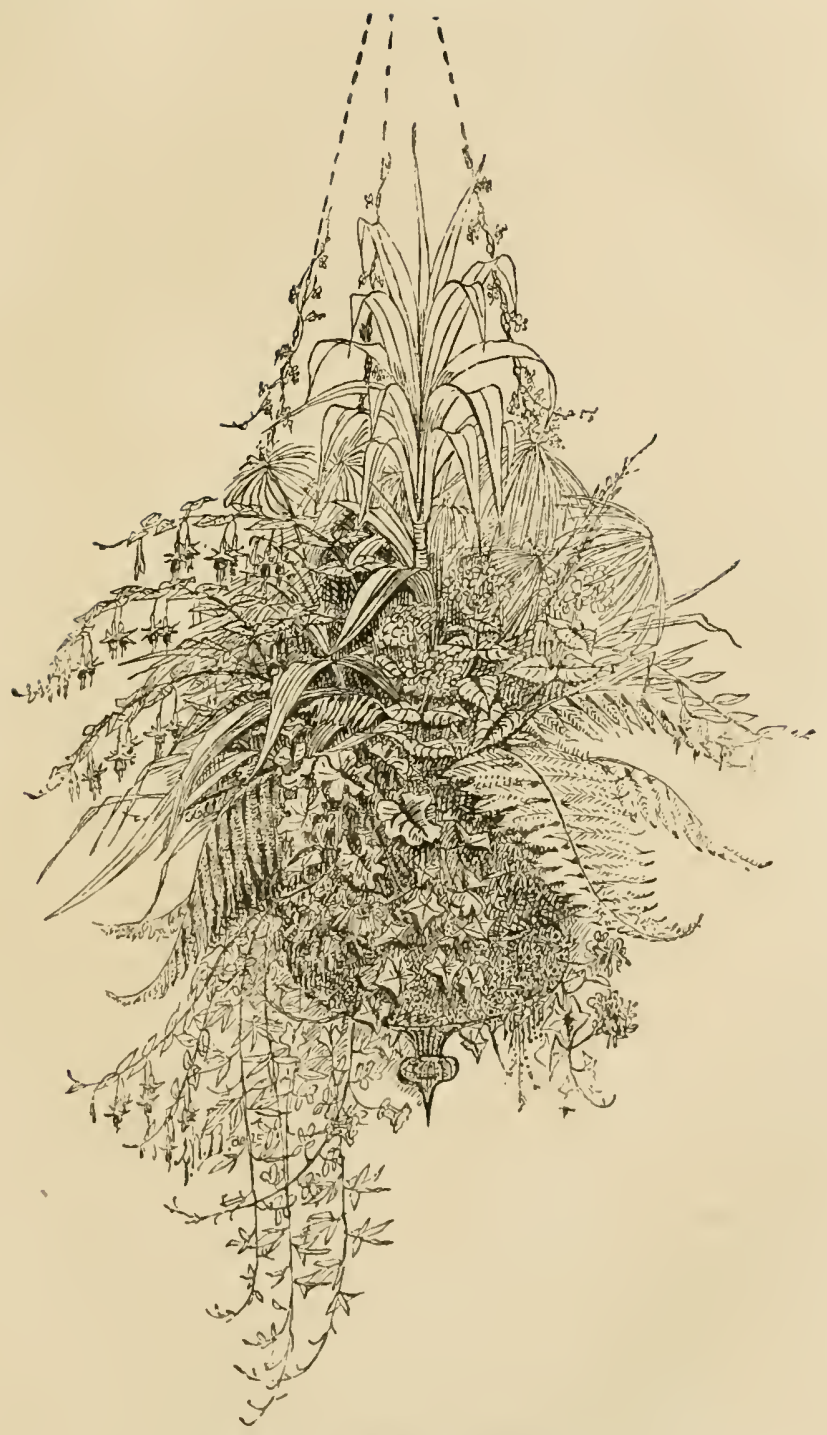

A Hanging Basket at South Kensington. 
as those that are ornamental. Where there is room, I like to see rather a large-sized case, in which large Ferns can be accommodated, and also a few small suspended baskets. As regards cultivation, the first thing that demands attention is the drainage of the case, for, if that is defective, neither Ferns nor other plants can be cultivated successfully. In order to secure good drainage the case should be fitted with a false bottom, into which the water may drain through perforated zinc or iron, on which the rockwork and little banks for the Ferns should be placed. The false bottom being a kind of little tank or drawer, if I may so term it, should be perfectly water-tight, so as to protect the carpet, and should have a tap fixed in one corner of it, by means of which the surplus water, drained from the Ferns, may be drawn off. To be able to give free ventilation to the plants every morning is another essential point, as a stagnant atmosphere is almost as injurious as stagnant water. Over the perforated tray of the case a good layer of broken crocks should be laid, and these should be covered with Cocoa-nut fibre, on which the rock-work should be set. The space in which it is intended to grow the Ferns should then be filled in, and I may say that nothing is better for this purpose than peat, rotten turf, and sharp grit sand. In the parts of the case intended for the planting of rather strong-growing Ferns, a larger proportion of rotten turf should be mixed with the peat than in those intended for less robust varieties. The next thing to be considered is what kind of Ferns to plant in the case. I should recommend 
some of the following:-Acrophorus chærophyllus, A. hispidus, Adiantum cuneatum, Anemia adiantifolia, Asplenium striatum, bulbiferum, Pteris serrulata, and all kinds of Trichomanes and Selaginellas. If the Fern case be large it might be advisable to have

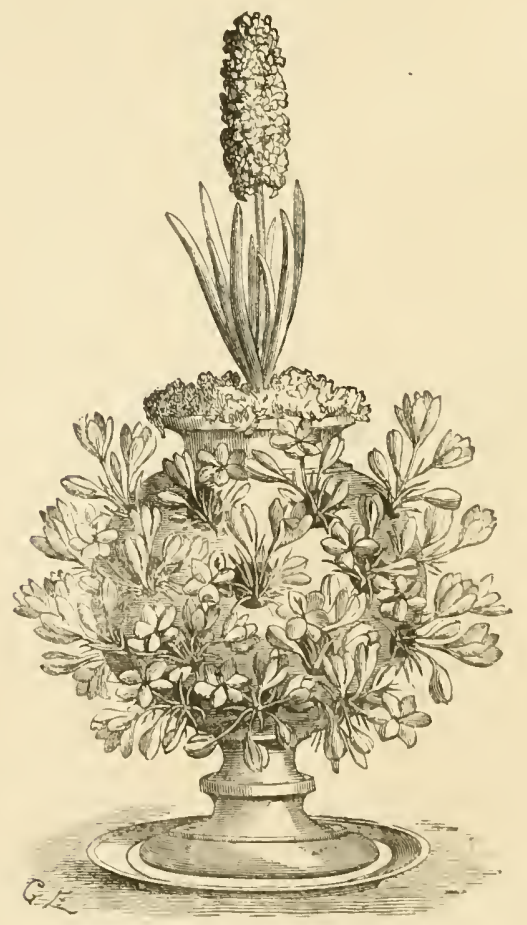

A Perforated Vase for Spring Flowers.

an arch reaching from end to end, over which could be trained two plants of creeping Ferm (Lygodium scandens), one planted at each end. From the centre of the arch a tiny basket filled 
with Selaginella Martensii variegata might be suspended. In planting Ferns care should be taken to place the dark green varieties next the light; in fact, to produce light and shade, and not to plant them just as they come to hand.

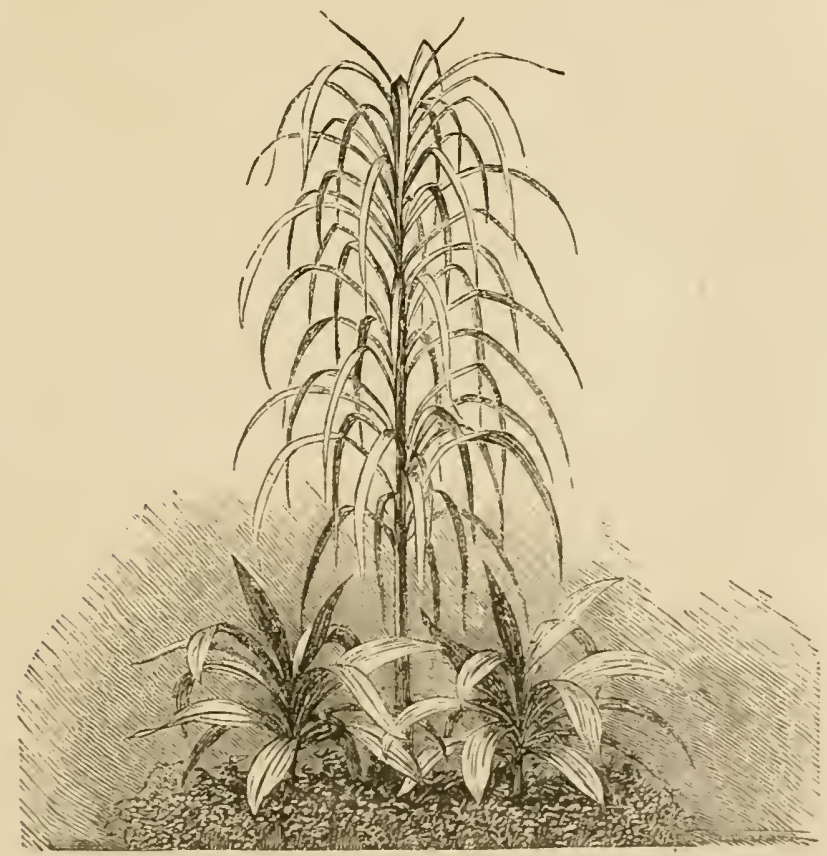

Window B $)$ x Furnished with Dracænas.

\section{Stands of Plants.}

Another farourite style of indoor decoration is wire stands filled with pot plants; some have them so that the plants can be arranged in tiers one abore 
the other; but I prefer a flat stand like a table, on which the plants can have plenty of Wood Moss packed round the pots. It is a good plan during summer to wash the Moss well with water before placing it between the pots; but care must be taken to squeeze all the water which it contains out of it, otherwise it is liable to drip; damping the Moss, however, tends greatly to keep the plants fresh during the hot summer months. Dracænas, and hardy Palms are well suited for this style of decoration, but they require to have their leares sponged now and then. Once a week will be often enough to water plants set in Moss; the plants should be lifted out of the stand, well watered, and, as soon as drained, returned to their respective positions; flowering plants, when they can be obtained, may be intermixed with the Palms and other foliage plants with good effect. Stands such as these are well suited for the decoration of a restibule.

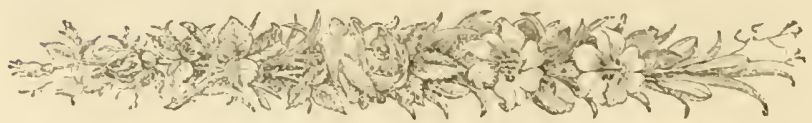




\section{CHAPTER XIX.}

PLANT STANDS FOR HALLS.

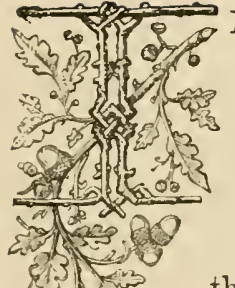

$\mathrm{N}$ outer halls stands of growing plants form very effective ornaments, but the plants selected for this purpose should be such as will not feel the effects of cold currents of air; for, during the winter months, in an outer hall, they would, of course, be subject to sudden changes of temperature; while, during the summer, almost any plant may be placed under such circumstances with the greatest safety. The size of plants used for this purpose must bear some kind of proportion to the size of the hall in which they are placed; and, as to the shape and the material of which the stands are made, that must depend on the taste of the purchaser; but the dearest and most ornamental, when fitted up, often do not look so well as those of a less decorative character. The plant selected for the centre should always be the tallest, a Dracæna, Cocoa-nut Palm, or India-rubber plant, being best adapted to this purpose. Round this should be grouped other plants remarkable either for flowers or foliage, which will be set off to advantage by that selected for the centre. Round the 
edge should be placed something of a drooping character, which will hang down gracefully and produce a good effect. For a stand in a hall, which is not heated in any way, there are no plants better suited than hardy British Ferns, which withstand cold dranghts well, and preserve their foliage fresh and green all the year round. For town houses nothing is so suitable as Ferns, as they grow well where other

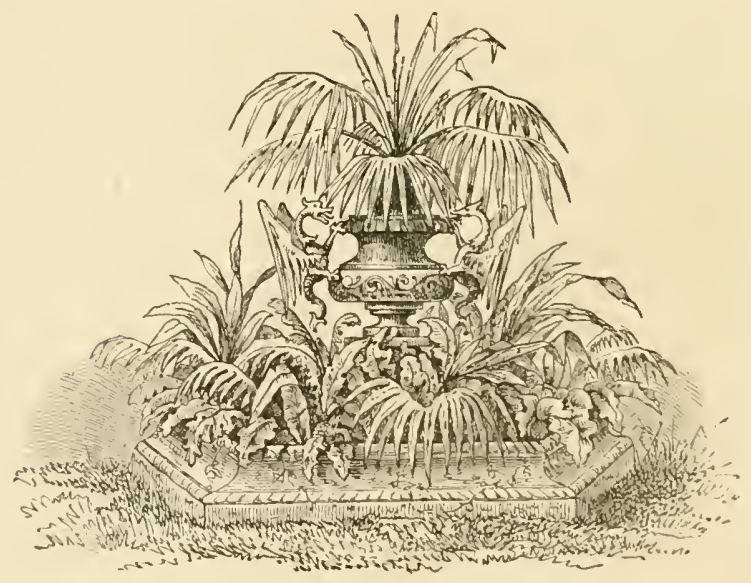

Vase and Basin furnished with Plants.

plants would droop and fado in a few days. $\Lambda$ handsome stand of British Ferns could be arranged as follows:- In the centre should be set a tall plant of Lastrea Felix-mas; then, grouped round it, a few plants of Scolopendrium vulgare, and again, outside these, such varietics as Asplenium Adiantumnigrum, $\Lambda$. marinum, $\Lambda$. Trichomanes, Blechnum Spicant, and Polypodium vuIgare. The Parsley Fern 
(Allosorus crispus), too, should not be forgotten. Ferns succeed best when each is set in a separate

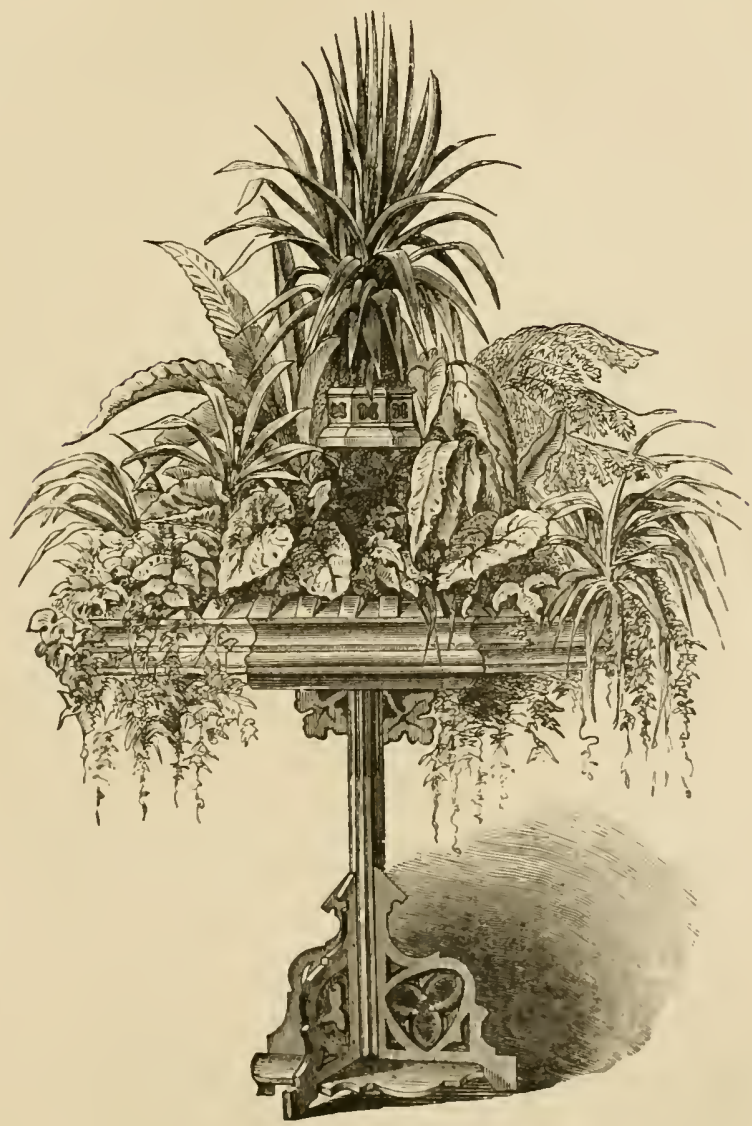

A useful Plant Stand.

pot, and, when planting them in this way, care should be taken not to crush any of the fronds, for, 
if bruised, they fade at once. The size of the pots should be regulated by the stand in which they are to be placed; if a large one be employed, the pot in which the centre Fern is to be planted should be a 24-sized one; for those outside of it 48-sized pots will

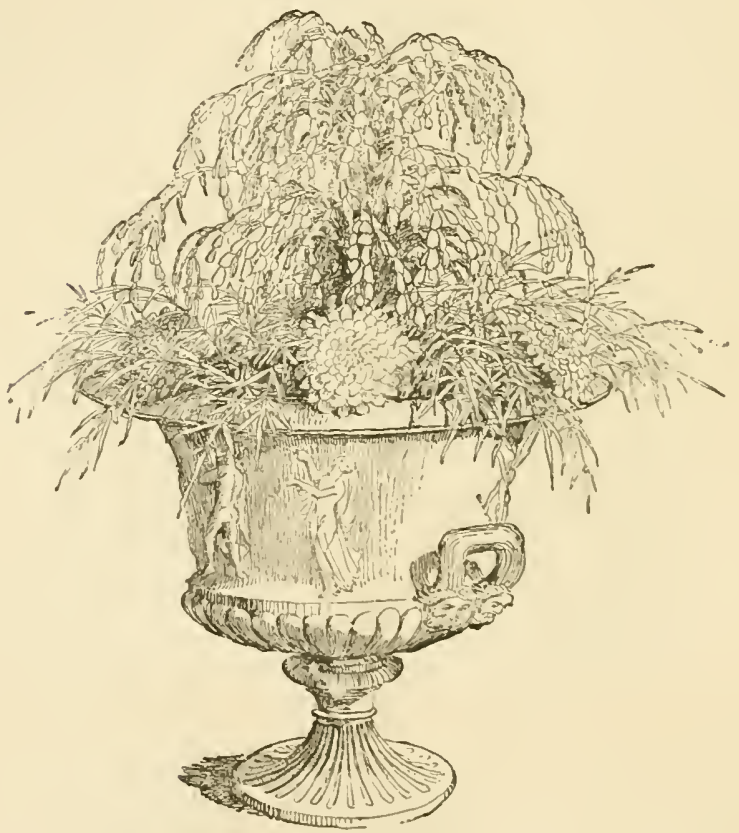

A Christmas Vase.

be large enough; and for those round the outer edge 60 -sized ones will suffice. In the bottom of each pot should be placed some broken crocks for diainage -not, as is too often the ease, thrown in carelessly, but placed so that the moisture will drain down 
through them, without the soil choking them up. Over the crocks a little Cocoa-nut Fibre, or Moss, should be placed, then a mixture of leaf mould, rotten turf, and peat, a good dash of silver sand being thrown in to keep the whole porous. On the surface of the pots, and between them, should be put Wood Moss, as in the case of stands for sittingrooms. A common seed-pan filled with Selaginella denticulata dropped into a small vase has a fine appearance; long sprays grow out over the sides of the vase, and droop down 8 or 10 inches, producing a charming effect. During the summer time a few Roses, or similar flowers, might be placed, if desired, amongst the Selaginella.

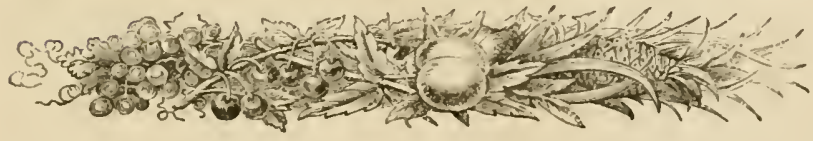




\section{CHAPTER XX.}

THE GROUPING OF PLANTS IN ROOMS.

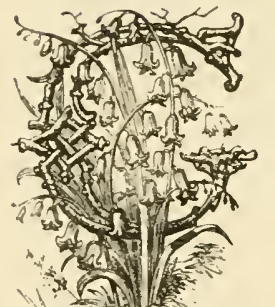

ROUPS of plants arranged with good effect in sitting-rooms, or on staircases, are important objects, and should, therefore, be grouped with care and taste. Much, I need hardly remark, depends on the latter, though I am sorry to say this point is too

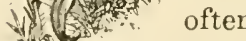
often neglected, the plants being crushed up in corners in a careless manner, with a seeming indifference to general effect. I think I cannot do better than give the chapter on this subject written by Mr. F. W. Burbidge in his excellent book on "Domestic Floriculture:"

"The arrangement of decorative plants in rooms for" effect demands some degree of taste, just as the composition of a beautiful bouquet or elegant wreath of flowers does. Plants judiciously arranged look better and grow better than when neglected, consequently this subject is well worth the attention of all who grow plants for the decoration of apartments. Plants when grown in a well-constructed greenhouse obtain abundance of light from all points; but in an ordinary 
apartment the case is different, all the light being derived from one or two windows, and from one side of the room only. Soft-wooded plants, or those with soft leaves, should be arranged as near the window as possible; and if they are re-arranged once a week and turned round to the light they will be all the better. Hard-leaved plants, as Palms, Agaves, Iry, Ficus, and the Kangaroo Vine (Cissus antarctica), may be grown in any part of a well-lighted room, and if tastefully grouped will add very materially to its appearance. Zinc pans neatly enamelled or painted may be used in the case of large pots which have to be set down on the floor or carpet. For smaller plants, which require elevating near the light, neat rustic jardinettes or ornamental flower-stands may be used with excellent effect. A good bold plant may be chosen for the centre, and the smaller kinds can be grouped round it in a tasteful manner. Aroid all stiff or formal arrangements, and get as much of the free and unrestrained grace of Nature in your window-boxes and flower-stands as possible. Do not train beautiful trailing-plants over ugly ladders or globe trellises, but allow them to droop naturally from a bracket or hanging-basket. Brackets are very useful for Begonias, Ficus, Isolepis, and other plants. For the centre of your window or flower-stand, a Yucca, Ficus, Agave, Dracena, Curculigo, or any other distinct and effectire plant, may be used with good effect. Yucca quadricolor grown out of doors during the summer becomes beautifully tinted with erimson, and is a noble plant for the centre of the flower-stand during winter. Agave variegata or Ficus elastica may be used in the 
same way. For edgings, nothing can be better than small succulents in pots, such as Echeveria globosa, E. secunda, E. californica, Sempervivums, or Echinocactus Eyriesii. If something more graceful is required, Isolepis gracilis and Festuca glauca may be arranged alternately, and are very effective-the one being of a fresh green colour, while the other is pale blue. If wire-stands are employed, they should be furnished with zinc pans to prevent any moisture from falling on the floor or carpet after the plants are watered. Ivy grows well in the shade, and may be employed for trailing around sofas or couches, rustic picture-frames, positions in which its beauty is seen to the best advantage; and if the frame contains the portrait of some departed friend, Ivy is perhaps the most appropriate of all plants for the purpose here suggested. When Ivy is grown for wreathing picture-frames, plant it in a wedge-shaped tin or zinc receptacle, and hang it on a nail in the wall behind the picture. Where Iry is trained on the wall outside the window, a few long shoots can easily be introdnced and trained over a neat arch inside; and its fresh green foliage will render the look-out much more beautiful by softening off the harsh angularities of the builder or architect. Many succulent plants are well suited for the decoration of apartments during the winter montbs if kept dry. They may be grouped on a table or sideboard opposite the light, and will prove far more interesting than a number of debilitated Geraniums. Plants of permanent interest are always useful, and add greatly to the appearance of such flowering-plants as may be from time to time grouped with them. Those who 
possess conservatories and greenhouses can always bring tender plants into the house for decorative purposes, removing them again when they have done flowering or are showing signs of exhaustion. In this, way many plants can be used for the decoration of apartments or ball-rooms without doing them any permanent injury. The plants generally employed by floral decorators for this purpose are-Palms of all kinds; Dracronas, as D. congesta. D. robusta, D. terminalis, D. rubra, and many others; Phormium tenax, Curculigo recurvata, Cycas circinalis, C. revoluta, Ficus elastica, F. macrophylla, F. lanceolata, F. falcata, F. Chauvierii, and F. dealbata; while the pretty little F. (repens) stipulata, and its even more elegant variety F. minima, are much used for wreathing slender pedestals or stands. For forming fresh green carpets nothing equals Selaginella Kraussiana (hortensis); and this or wreaths of common Iry may be used to conceal the pots of foliage plants, or Hyacinths, Lilies, and other flowering-plants, as may be required. Cyperus alternifolius is a fine decorative plant, and quite distinct from anything else; while all the Aralias are bold and stand well in rooms, especially if they have been grown in the open air during summer. Ivy, Aralias, and many other half-hardy shrubs and herbaceous plants, may be grown in corridors or on the staircase-landings where there is sufficient light; or these can be decorated temporarily with tender plants. The staircase itself may be covered with crimson baize and then looks very beautiful fringed on each side with Ferns, Isolepis, Palms, and flowering-plants, such as Begonias, 
Lilies, Vallotas, Chrysanthemums, or Spiræas. The corners, and often the sides, of reception saloons, or ball-rooms, are now most beautifully decorated with groups of graceful Ferns, Palms, Cycads, and Ynccas, Mirrors or pictures may be festooned with Ivy wreaths, and garlands or flat bouquets may be suspended beneath the gas-brackets. Choice flowers of bold form and distinct colour may be used in any quantity, provided that they are tastefully and judiciously arranged. Stephanotis, Tuberoses, choice Orchids, Lilies, Eucharis, and other exotics, may be laid on cool beds of Moss or Selaginella beneath graceful Palms and elegant umbrella Sedges (Cyperus). Plants of the Trumpet Lily (Richardia) are specially effective. when grouped with statues or elegant vases, while flowers and foliage of the common white Water Lily (Nymphæa) or Gladioli are rery pretty in tasteful groups. For some time past, Mr. John Wills, one of our most extensive floral decorators, has used huge blocks of real ice tastefully arranged in the form of obelisks and rockeries. These, when illuminated from behind and wreathed with Ficus repens, Creeping Jenny, Iry, Lygodium scandens or Virginian Creeper, are very beautiful, and give one a most delicious idea of coolness even during the hottest of summer weather. At a ball given by the Prince and Princess of Wales to the Czarevna of Russia in the large conservatory of the Royal Horticultural Society at South Kensington, 10 tous of the finest ice were employed in building an illuminated rockery. This was draped with drooping Ferns and graceful trailers, while the base 
was fringed with slender-growing Ferns and small pots of Isolepis gracilis and Selaginella. The effect of the whole when surrounded by crimson baize and illuminated from within, was strikingly effective and much admired. In using ice in this way, prorision must be made for collecting or carrying off the water from the ice when thawing. In the case of solitary blocks or obelisks they can be arranged over claret casks sawn in half and concealed by Ferns and trailing plants of various kinds. Blocks or obelisks of sparkling ice are sometimes used on the dinner-table with good effect. In this case tables with deal tops are used, and the cask or vessel to collect the drip is concealed beneath : wreathed with fresh trailers and well lighted these are very handsome. In grouping plants the largest should, of course, stand behind, care being taken to give due prominence to the central plant in each group. Even common plants may be made to look effective in apartments if a little taste, forethought, and judgment be exercised in their arrangement. For grouping in baskets we have numerous elegant trailers, the best for room-culture being Saxifraga sarmentosa (Sailor-plant), S. Fortunei, S. tricolor, Sedum spectabile (S. Fabaria), Fragaria indica, F. vesca, and F. semperflorens, Linaria cymbalaria (Toadflax or Coliseum Vine), Tradescantia zebrina, T. viridis, Thunbergia alata, Convolrulus mauritanicus, Lophospermum scandens, Lonicera aurea reticulata, Asparagus decumbens, Mrrsiphyllnm, Cereus flagelliformis, Crassula lactea, Panicum variegatum, Iryleaved Geraniums, Tropæolum tricolorum, T. Lobbi, T. 
perigrinum, or Canary Creeper, Selaginella Kraussiana (S. denticulata), Lysimachia nummularia (Creeping Jenny), Vinca minor, both green and variegated kinds, Ampelopsis Veitchii (A. tricuspidata), and all the beautiful hybrid Clematises. The arrangement of plants in close cases and shades is simple, but care should be taken to place the strongestgrowing plants in the centre and the smaller ones at the sides. Do not crowd jour cases or shades with common plants, but reserve them for interesting Ferns or other little curiosities that will not grow in the open atmosphere of an ordinary apartment. Interesting collections of tender Ferns and Pitcher-plants may be grown in these handy little contrivances with but little trouble. The following list comprises some of the prettiest and most interesting plants for a closed plant-case in a heated room:- Selaginella denticulata, S. apus, (S. densa), Nertera depressa (Colal-berried Moss), Dionæa muscipula (American Fly-trap), Drosera rotundifolia (Sundew), D. dichotoma (D. binata), D. spathulata, Cephalotus follicularis (Australian Pitcher-plant), Darlingtonia californica (Californian Pitcher-plant), Sarracenia purpurea (Huntsman's Cup), S. flara (Side-saddle Flower), S. Drummondii, Nepenthes phyllamphora (True Pitcher-plant), Platycerium grande, P. alcicorme (Stag's-horn Fern), Mammillaria acanthophlegma, M. crucigera, M. bicolor, Kleinia fulgens, K. tomentosa, Stapelia of sorts (Carrion Flowers), Masdevallia Lindenii, Odontoglossum Alexandra, Opuntia cylindrica, $O$. mierodasys, and many other plants equally interesting." 


\section{CHAPTER XXI.}

\section{THE GLADWIN AND ARBUTUS FOR DECORATITE PURPOSES.}

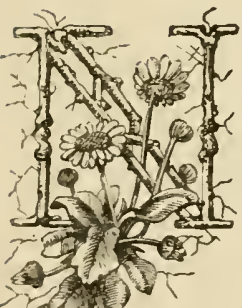

OT until lately has the Gladwin species of Iris come into notice. It seems to hare been overlooked in this country, so far as its decorative adaptability is concerned, and it is only lately I have used it myself for purposes of ornamentation; for the future, however, I shall never lose an opportunity of availing myself of its bright and effective seed-pods whenever I can obtain them. Arranged amongst evergreens, in stands of every description, it is very ornamental. For Christmas decorations, it sbould take a leading place amongst berry-bearing plants. Its brilliant orange shade of scarlet, and its graceful drooping habit, make it highly effective in garlands and large decorations formed of evergreens, such as are generally used at that period of the jear. The seed-pods are sold in bunches in Corent Garden Market at a very cheap rate, which brings them within the means of all classes. I mysclf had some spikes of this Iris, or Gladwin, as it is often called, in use 
in a stand, amongst evergreens, for more than a month; and, with the exception of the berries being shrunk a little, they appeared as fresh as when first placed there, and their colour quite as bright. These seed-pods also look very well if employed in connection with fruit, but they must be mixed with Fern fronds, or some other foliage. I have placed the pods in the Moss that covers the soil of pot plants, selecting those which were opened out to theil fullest extent, and placing them so as to rest flat on the Moss; used in this way they have a very pretty effect. If used for church decoration they will form, I am sure, a very important adjunct. In "Pratt's Flowering Plants of Great Britain," this Iris is described as haring leaves sword-shaped; perianth, beardless; its inner segments about as long as the stigmas; its root perennial. It is not nearly so showy a flower as the yellow Iris, for its petals are of a dull bluc, or, in some instances, a dingy yellow. The plant has a singular odour; and, while it is untouched, this is not disagreable, but, if we break the stem, or crush a leaf, its scent bəcomes extremely unpleasant. This Iris generally grows to the height of 12 or 18 inches; and, though a local plant, is common in the west and south-west of England. It is abundant in the woods and thickets of Devonshire, and grows in several parts of Kent in dry hedges, or, as in the neighbourhood of Hythe, along the cliff coast, and on bauks near Dover. It bears its flowers from June to August. Its secds are very bcantiful in winter, whon their capsulo shrivels, and displays them in all 
the lustre of brilliant scarlet. They are numerous, and most powerfully acrid. Mr. Sowerby, in "Our Useful Wild Flowers," after speaking of Iris pseudacorus, says:- "The only other British Iris (Iris

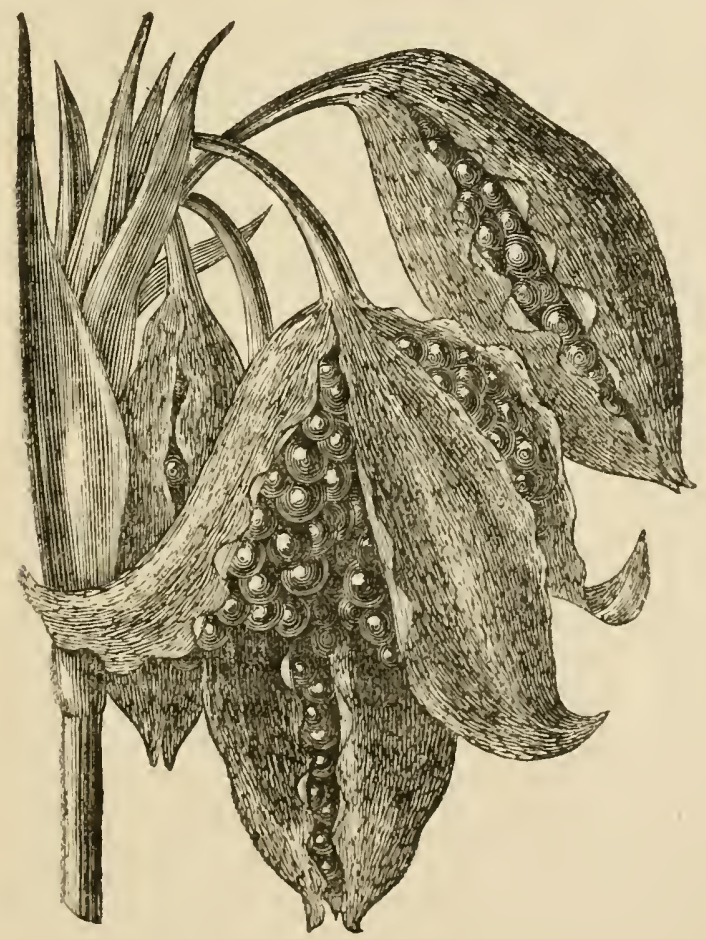

Seed-pods of the Gladwin (Iris fortidissima).

footidissima), remarkable for its rery peculiar scent, has been applied to the same medicinal purposes as the common species. It is abundant in some parts of the west of England; but it is local elsewhere. 
The leaves are shorter, narrower, and of a darker green than those of the other kind. The flowers are purple, and are followed by the triangular seedvessels, which, when ripe, open, disclosing the beautiful orange-coloured seeds, and rendering the plant very ornamental in the autumn." Most of those exhibited in Covent Garden Market for sale come, I believe, from Essex, where, I should suppose, they are cultivated for that purpose; but Iris fœetidissima is to be found abundantly in a wild state in many parts of southern England and Ireland, as well as in the localities above-mentioned.

\section{The Arbutus Flower and Berry.}

Amongst berry-bearing plants, the Arbutus is one which claims our attention for decorative purposes perhaps more than any other in this class, owing to its usefulness when in a flowering, as well as a berry-bearing, state. Indeed, it would be a hard matter to decide in which stage it may render most service. When in flower its diminutive bells, looking like wax, are equal to those of any light-coloured Heath, and when in berry it is invaluable for mixing throngh evergreens or for the decoration of fruit. Before arranging the blooms amongst other flower's, all the leaves should be ent off; if left ou they look heary, and spoil the general effect, but when placed amongst other evergreens this will not matter. I first saw the bloom of the Arbutus (in a monnted state) employed amongst other flowers in a buttonhole bouquet, and for a moment or so I could not 
make out what it was. During the autumn months when flowers are difficult to obtain, it will be found most useful, and the berry equally so later in the season. There are many other berry-bearing plants, most useful for decorations, but it would be impossible to enumerate them all, so I have selected the two varieties above for example.

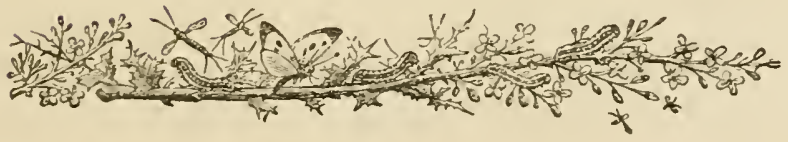




\section{CHAPTER XXII.}

LEAF PRINTING FROM NATURE-HOW TO SKELETONISE LEAVES.

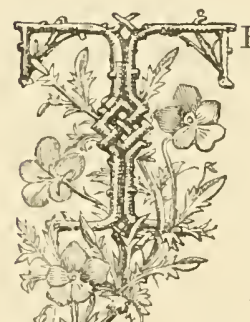

HE following paper, on the subject of "Leaf Printing," appeared in the pages of "The Garden," and, through the kindness of Mr. W. Robinson, I am permitted to use it in this work. There are several different methods in use for photographing leaves, some of

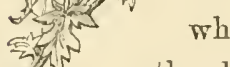
which are exceedingly simple. First select the leaves, \&c.; then carefully press and dry them. If they are placed in a botanical press, care must be exercised not to put too great a pressure on the specimens at first, or they will be spoiled for printing. I have always found an old book the best for drying the examples to be used. Fibrous leares-such as the Birch, Oak, and Maple-make the best photographs. Never think of printing leaves which aro either covered with hairs, or are rough and uneven; it will only lead to unsatisfactory results. Mature leaves only should be gathered-not those that are suceulent or young-neither attempt to print any leaf with a thick epidermis, such as Bay leares. The best for a beginner are the fronds (leaves) of Ferns, the 
Maiden-hair, Parsley, Hart's-tongue, and Polypody, Sea Spleenwort, the little Wall-rue Spleenwort, and Centipede Spleenwort. In fact it would be difficult to find any Fern that will not produce excellent results. The most lovely album pictures I have ever seen were printed from Fern fronds by one of the following processes. Not only are they pretty objects, either framed for mantelshelf ornamentation or in the album, but botanists, and more especially every gardener who is interested in pteridology, should print the fronds of every species of Fern they can procure; afterwards mount them in a blank book, on the left hand page; then, on the right hand page, write the name and habitat, with a description by which it may be recognised, the method of cultivation, and any other useful memoranda. By this means, in a short time, he will have compiled a volume full of deep interest and utility. Many persons cannot afford to purchase expensive works on pteridology, yet they may soon form a permanent record for their own reference, which will be more valuable to them than any other work. I throw in these remarks as a hint worth notice by practical horticulturists.

\section{Requisites.}

The requisites for Fern photography are two pieces of glass of the size you intend jour pictures to be ; common window or crown glass, without air bubbles, which may be bought from any glazier, will answer the purpose admirably. For the last process described, one of the glass squares should be cut in two equal parts, and a strip of muslin pasted over the division 
to form a kind of hinge. Then you will require paper, which should also be of one regular size. If a photographer was asked as to the best kind, he would at once recommend the albumenised paper which he uses for his carte-portraits; but, as I wish to point out how to work cheaply as well as efficiently, I would request my readers to use only the best wore letter paper. With a sharp pointed penknife jou may afterwards cut it the size jou wish. I must warn the inexperienced not to use what is known in the stationery trade as "laid paper." We often see on the quarterream packet of note paper the words "the best creamlaid note;" nerer use this-it will not succeed if you do. On the laid paper the peculiar wire marks left by the manufacturer are to be seen when held up to the light; eschew this kind by all means. The wore papers are devoid of these marks, and white paper only of the latter kind should be used.

The above comprise the necessary materials wherewith to work-the "stock-in-trade," in fact. It is well, however, to have at hand a few American clothes-pegs, or spring clips, which may be purchased for a penny each from most ironmongers; and, of course, a few chemicals are required. In working with these great cleanliness must be observed. Hard or spring water must not be employed; use, if you can procure it, nothing but distilled water, or-what will answer equally well-clean and pure rain water. The chemicals requisite are-nitrate of silver, prussiate of potash, bichromate of potash, blue vitriol (sulphate of copper), and hydrosulphate of soda. Keep the chemicals in bottles pro- 
perly labelled, to prevent any accidents and confusion; they will not bo kept so cleanly if preserved in papers.

\section{Photographic Printing.}

We will first describe the most simple mode of photo-printing, and then proceed to more difficult and complex formulas. Dissolve, in a clean half-pint medicine bottle, four drachms (half an ounce) of prussiate of potash in about four tablespoonfuls of rain water. When it is all dissolved, so that none is visible in the bottle, pour half of the solution in a dinnerplate, and float on its surface, for a few minutes, a sheet of paper of the size inteuded. After enough of the chemical is absorbed, hang it up on the edge of a shelf, by sticking a pin through one of the corners, to dry. All these operations should be performed in a dark room; a candle, however, may be used, because the rays of light emitted by it, being yellow, do not affect the sensitised or prepared paper. A better plan, perhaps, is to brush the solution over the paper by means of a large camel's-hair pencil. Let cleanliness be obscrved, or the attempt will end in failure and disappointment. Lay upon one of your glass sheets three or four folds of white blotting paper: upon this, the dried and sensitised prussiate of potash paper, with the prepared surface uppermost; and upon this place the Fern-frond or other selected and dried leaf. Upon the leaf lay the other sheet of glass (perform all this in the dark room), and then, to keep the leaf and sheets from moving, fasten one of the clothes'-clips on each end. Place the glass in the 
open air, under the direct influence of clear sunlight if possible. If the day is at all cloudy, it will take much longer to print; but, with a clear sky, \&c., it will probably be half an hour or so before it is sufficiently exposed. Be sure, however, to expose it a sufficient length of time; a little practice will soon teach you how long to leave it in the sun. Now watch the paper, and you will gradually obscrve the part not covered by the leaf changing from a yellowish hue to a bright blue; the latter will deepen until it is almost black. When you believe it is sufficiently exposed to the sun's rays, remove the leaf, glasses, \&c., and you will find printed on the paper a yellow outline of the leaf on a deep blue ground. Now wash the paper in water, changing it frequently, until you observe the yellow change to a white-the whiter the better. By this means all the chemical is dissolved from the paper, leaving the part where the leaf lay a clear distinct white. If the glasses are removed too soon, the picture will be pale, and if they are left too long in the sun-light, the blue ground will fade.

\section{The Chromotype Process.}

This method is similar to the last, except that different chemicals are required to work it efficiently. Speaking personally, I have not suceceded so well with it as with the last process; some of my readers may, however, succed bctter. The chemicals required arepure sulphate of copper, bichromate of potash, and nitrate of silver. The latter should be handled with care, for if it comes in contact with linen it stains it 
black; the hands, too, suffer much, so that the skin is blackened and destroyed; it is therefore advisable to wear kid gloves when using the solution. The same kind of paper and glasses answer for this as for the former process. Dissolve about half an ounce of sulphate of copper in half a pint of rain water, and half an ounce bichromate of potash also in half a pint of rain water. The nitrate of silver is very expensive; very little, however, is required in any of the processes, and, for this, one drachm should be dissolved in an ounce of clear water. First coat over, as in the first method, one side of the paper with the copper solution, then, when it is dry, coat it with the bichromate solution. After drying the paper, expose it as before to the sun for about an hour; then, if you think it sufficiently exposed, coat it over with the silver solution; or, the process may be reversed, if albumenised paper be employed. The veins, \&c., in this method should be a bright scarlet. The papers may be prepared for use some time before they are required.

\section{The Best Process.}

The best process of Nature printing is, without doubt, the following, although it requires much more care, patience, and neatness than the foregoing. As the prepared papers are exceedingly sensitive to light, the dircetions in respect to a dark room must be strictly adhered to. The chemicals, which should always be dissolved in bottles ready for use, are as follows:-First, a solution of nitrate of silver, containing one drachm or sixty grains to each ounce of 
pure or filtered rain water; any druggist will prepare this solution in a few minutes with distilled water, which can be relied upon for good results. Then a solution of hypo-sulphate of soda is needed, containing two ounces to each half-pint of water. To work well, and securc prints that may be relied on, ase only the albumonised paper, which is kept ready for sale by every photographic chemist; and, if possible, procurc a glass rod, to save the hainds from being stained. Always have the bottles containing the solutions correctly labelled. When you have cut the paper to the size required, pour the nitrate of silver solution on a shallow dish, and float the pieces of paper separately, with the prepared surface on the liquid, for about ten minutes. In doing so, take care no air bubbles are beneath the paper, or it is useless for printing; when you detect any bubbles, gently lift up the paper with the glass rod, and, taking hold of the corner with the finger and thumb of the left hand, remove the bubbles by touching the part with the rod. A little practice will soon make you perfect in sensitising the paper. After floating the papers for about ten minutes, take them out and drain them for a few minutes on the dish, so that no silver may be lost; then hang them up in a dark closet by pinuing the corner on a string suspended across the room. In scusitising the paper, always wear old kid gloves, as well as any old garments you may happen to have at hand-the solution is so liable to spoil the clothes and injure the skin that this advice is very needful. It is well to prepare a quantity of papers beforehand; they will keep for sereral days; the only 
difference is that newly sensitised papers print much more rapidly; some people say they give better pictures, and probably it is so; however, if they are to be kept, take care no sunlight is admitted to them. The printing part of the process is exactly similar to the first method, only it needs watching more carefully, and, in using the glasses, place the one cut into two parts and hinged at the bottom beneath the blotting-papers and Fern fronds; when the printing is going on, you can turn them up and examine the picture, only do not displace the leares ever so slightly or the picture will be useless. A good rule is to print the picture much darker than you intend it to be when complete, because in the fixing process it becomes much lighter. After being exposed, wash the print in clean water to take away the excess of silver-you cannot wash it too well; then, having placed the hypo-sulphate of soda solution in another dish, place the picture beneath it. Do not float it as in the bath, but constantly keep it moving about with the fingers for about fifteen minutes, not longer. This is to fix the impression and make it a permanent picture. Then wash it, changing the water frequently. Do not allow a drop of the fixing solution to remain on the paper, or it will stain it yellow, which, if nothing more, will make it unsightly. All you have now to do is to dry the picture either in a book or between folds of blotting-paper beneath a gentle pressure. The last process is, after all, the best, yielding permanent and truthful results. Some Fern variety, which perhaps has never been figured in any book, by 
this means can be printed "true to Nature," and can be referred to with pleasure in after years. I have seen a fair-sized rolnme containing on one page a Nature-printed or photographed Fern frond, and on the opposite page, as deseribed above, a short but correct and faithful description, \&e. This was the best volume on British Ferns and their varieties I have ever seen.

\section{How to Skeletonise Leaves and Seed Vessels.}

To the charming arrangements that can be made of the above I need hardly draw attention, as their usefulness in groups for the ornamentation of sittingrooms is too well known to need comment from me; but I wish to draw attention to the ease with which these pretty stands ean be made. The only fault, perhaps, to be found with them is, that if exposed to dust, \&e., they soon lose their beanty, and, for this reason, should always be placed under a glass shade. The following deseription of an excellent method of preparation, like that of leaf printing, appeared in the pages of "The Garden":- "The old methorl, as most of my readers are avare, was simply to immerse the leaves in water for several weeks until the epidermis and parenchyma had decayed; then, taking them ont, to rub off the decayed flesby or cellular matter iu a bowl of elean water. To say the least of this method, it was very unsatisfactory, and often yiclded results far from pleasing, without taking into consicleration the great amount of patience needful to complete the process. Now, thanks to chemistry, we have another and a better plan, not occupying as many hours as 
the old decaying method took weeks to accomplish. An excellent recommendation for processes of this kind is their simplicity; as anything complicated or requiring expensive materials in its performance is sure to be scouted, or, at most, to gain but $\mathrm{fcw}$ adherents. Most of my lady friends, to whom I have recommended the undermentioned process for skeletonising leaves have fallen so much in love with it as to follow it up constantly in the autumn merely for amusement. The result has been the production of many an elegant draving-room ornament, either placed in the vase or mounted for framing beneath glass as a permanent record of their industry. First dissolve 4 ounces of common washing-soda in a quart of boiling water, then add 2 ounces of slaked quicklime, and boil it for about fifteen minutes. Allow this solution to cool; afterwards pour off all the clear liquor into a clean saucepan. Wken the solutiou is at the boiling point, place the leaves carefully in the pan, and boil the whole tegether for an hour. Boiling water ought to be added occasionally, but sufficient only to, replace what is lost by evaporation. The epidermis and parenchyma of some leares will more readily separate than those of others. A good test is to try the leaves after they have been gently simmering (boiling) for about an kour, and if the cellular matter does not easily rub off betwixt the finger and thumb beneath cold water, boil them again for a short time. When the fleshy matter is found to be sufficiently softened, rub them separately, but very gently, beneath cold water until the perfect skelcton is exposed. The skelctons at first are of a 
dirty white colour; to make them pure white, and, therefore, more beautiful, all that is necessary is to bleach them in a weak solution of chloride of lime. I have found the best solution to be a large teaspoonful of chloride of lime to a quart of water; if a few drops of vinegar be added to the bleaching solution it is all the better, for then the chlorine is liberated. Do not allow them to remain too long in the bleaching liquor, or they will become very brittle, and cannot afterwards be handled without injury. About fifteen minutes is sufficient to make them white and clean-looking. After the speeimens are bleached, dry them in white blotting-paper beneath a gentle pressure. Of course in this, as in other things, a little practice is needful to seeure perfection. Simple leaves are the best for young beginners to experiment upon-Vine, Poplar, Ficus, Beech, and Iry leaves make exeellent skeletons. Seed-vessels of the Thorn-apple (Datura Stramonium), and the Cape Gooseberry (Physalis edulis and P. Alkakengi) are casily prepared, and afford variety. Care must be exereised in the selection of leares, as well as the period of the year and the state of the atmosphere when the specimens are collected, otherwise failure will be the result. The best months to gather the speeimens are July to September. Nerer collect specimens in damp weather, and none but perfeetly matured leaves ought to be gathered." 


\title{
CHAPTER XXIII.
}

\author{
DRIED FLOWERS.
}

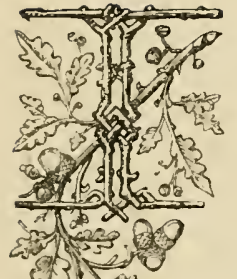

$\mathrm{N}$ nearly all the tables staged for competition in the classes for dinnertable decorations at our principal shows, you see wild Grasses used in the stands and table bouquets, and when arranged judiciously, a very if . is pleasing effect is produced-no matter an what colour the flowers may be with which they are mixed. If it be a bright or glaring colour, they will tone it down, and if of a delicate shade, they will suit even better. Grasses give a light effect when mixed with cut flowers that nothing else will give. I have no doubt if they could only be bought at Covent Garden or some bouquet shops, there would be a much greater run on them than there is; but, like many other things that can be bought cheap, or are easily obtained, they are not used as much as they deserve. It is the same with wild flowers-I have seen stands filled with these look much more elegant and chaste than those laden with gorgeous exotics.

In recommending Grasses, I do not mean that all kinds may be used; always select the most graceful 
and light looking. As it is only at one season of the year that these can be gathered, a good store should be laid in for winter and spring use. The waving and drooping kinds should be so placed that when they are drying they will be in the same position as when growing, otherwise they will lose their shape, which of course spoils their effect, and in drying the very light kinds, care should also be taken not to crush their heads together, as they will also lose their shape and become flat or one-sided. For those who have not any flowers at their command during the winter months, eharming little stands can be made up of wild Grasses with Rhodanthes and different kinds of everlastings mixed with them to give additional effect. Dried Ferns can be placed amongst them, which, if properly dried, retain their fresh green colour. One of the most effective flowers when dried is the Rhodanthe; both the pink and white varieties retain their colour and fresh appearance for a long time. The best way to preserve it is to reduce the amount of water by degrees till at last the stems become quite hard. They can then be cut off and put away for winter use, when they are most effective, both in hand and table bouquets. If the flowers are eut off while the stems are fresh and full of sap, they will be found to shrivel and look bad. I like to see and use the Rodanthes when the flower is closed, not open, but some might be saved in both or either states according to taste.

By taking a little trouble, pretty pictures may often he mado out of many Fern fronds considered useless in the greenhouse, or, at all events, by the use of a 


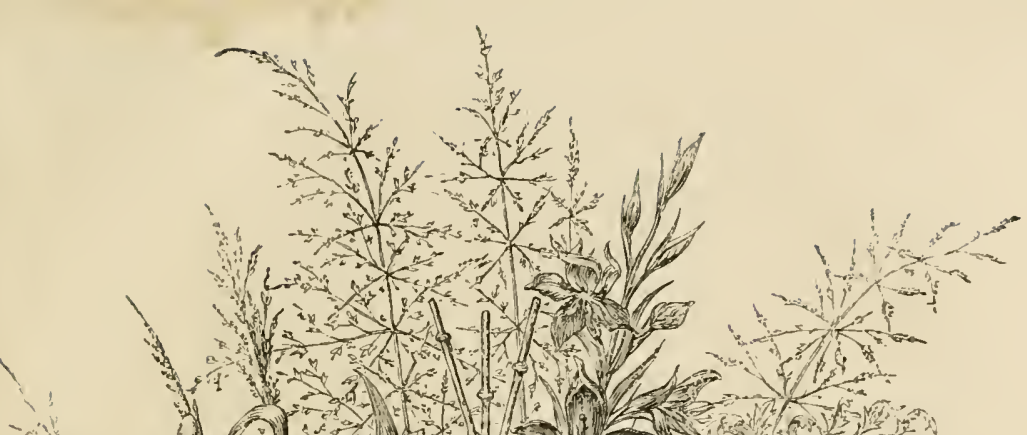

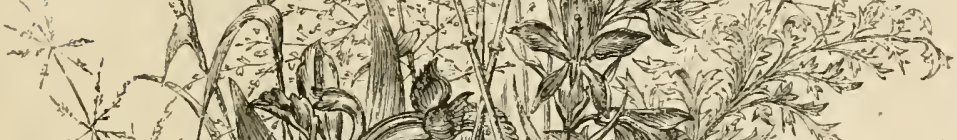

s.

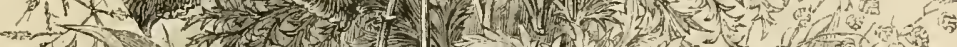

w.

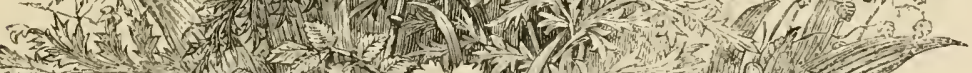

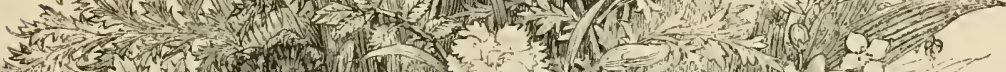
tร,

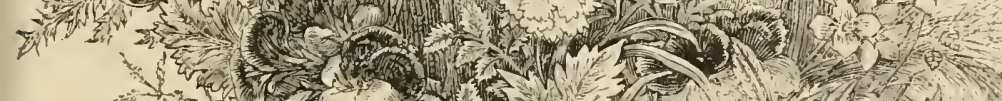

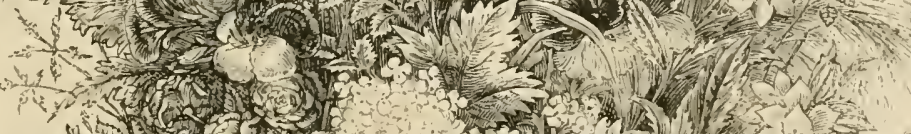

- $)^{2}$ Ul

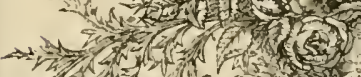

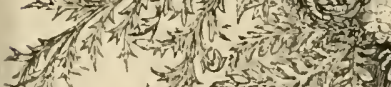

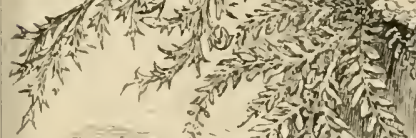

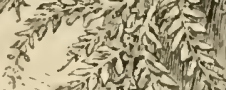

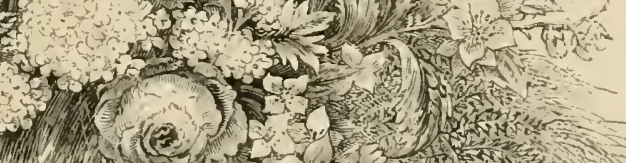

3. Plin)

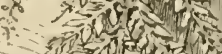

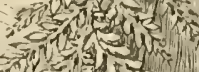
(I)

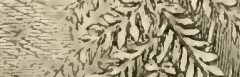

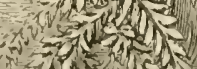

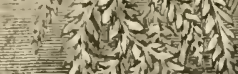
intersis

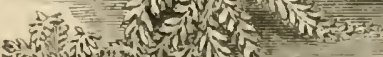

a.

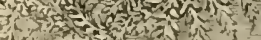
10

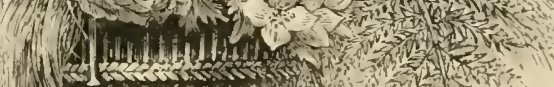
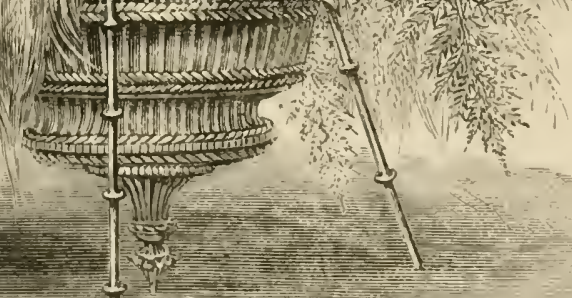

few which may be cut off and never be missed. After the Ferns have been removed, they should be dried between sheets of botanical drying paper; even old newspapers or blotting-paper will answer the purpose Presuming that a collection of dried Ferns is at hand, a sheet of good cardboard should be procured; some like it white; I prefer it slightly tinted, but that is altogether a matter of taste. The Ferns should then be laid lightly on it, and arranged in the form of a bouquet or whatever shape is desired. The position of each Fern should be indicated before it is glued down, as, after that, it could not be well removed without marking the cardboard. Supposing the fronds to have been arranged according to taste, they should be lifted up again, and their backs should be glued with a fine brush, so as to make them stick to the paper. Should any gold or silver varieties be amongst those selected, they should be placed so as to show the colour of the under-sides of the fronds. The light-coloured Moss, which is to be found growing on old trunks of trees, if interspersed through the Ferns, tends to give the arrangement a light and elegant appearance. A wreath of Ferns mounted in this way produces an excellent effect if placed round or under a handsomely illuminated text. The fronds selected for mounting in this way should be those of small and light-looking varieties, as large and heary-growing kinds would make a small arrangement of this description look heavy. In this way a capital book of reference on Ferns might be made up, each variety being monnted on a shcet of drawing-paper or cardboard, and the name of the variety, height of growth, natice country, $\&$ c., 
written under the frond. It is astonishing how very quickly a collection of this kind can be got up, as single fronds are easily obtained.

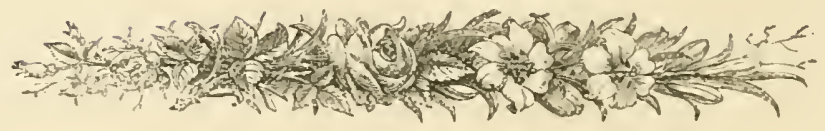




\section{CHAPTER XXIV.}

CHRITMAS DECORATIONS.

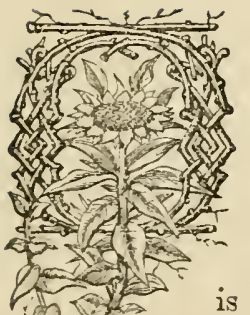

NE could hardly believe it was Christmas in the absence of Holly, Iry, and Mistletoe, which have so long at that season occupied prominent places in our households. The custom of decorating with erergrecns is far from being a modern one. The Romans, 2,000 Jears ago, did the same thing; indeed, it is more than probable that the origin of adorning our homes with Iry, Holly, and Bay, must be sought for in the Roman Saturnalia, beld every year towards the end of December. Formerly the decorations of rooms consisted of a few branches of evergreens stuck here and there as might be convenient; but now they are of a much more complicated character, and require time and skill in their manufacturc. Where decorations of any extent are annually employed, the week before Christmas is a busy time with the ladies of the household, as the making of the decorations principally falls to their share. To make effectire and pretty desigus requires good taste, practice, skill, 
and a general knowledge of the materials to be employed. A few hints, on this subject, therefore, may prove acceptable, as I have assisted in making many decorations at Christmas time, and so can speak from experience. First come under our notice the shrubs to be selected. Though Holly, Ivy, and Mistletoe are principally used, many other materials may be enumerated that are admirably adapted to intersperse with those mentioned above, and thereby tend to relieve that sameness which would occur were Holly and other ordinary Christmas evergreens only employed. Amongst others I may mention the following:-Arbutus, Aucuba, Bay, Euonymus, Gold and Silver Hollies, Ivies of different colours, Laurels, Laurustinus, Portugal Laurel, Spruce and Silver Firs, Yew, \&c.; also branchlets of Arbor-vitæ, C5press, Deodar, Juniper, Thuja, or any other ornamental shrubs obtainable. Having said so much for evergreens, let me refer to the foundations on which they are to be worked. These consist of the following, for, according to the style of decoration, so the foundation must be selected:-For garlands, wire or strong cord should be nsed; the latter is, however, preferable, as it is not so liable to twist as wire; and, for what are called upright wreaths or panels, fine iron rods are the best. For ornamental devices perforated zinc should be used; for letters, strong brown paper; for narrow beadings, where single leaves only are employed, tape wire; for crosses, picture frames, texts, \&c., flat laths, such as are used in the construction of ceilings by plasterers, or Hazel rods; and for wreaths strong wire; for small garlands 
fine twine is serviceable. In addition to the above, several balls of hemp twine (fine and coarse), large needles and strong linen thread (dark green or black), a pair of scissors, penknife, and reels of binding wire, must also be at hand; and, though last on the list, one of the most important articles to be supplied with is a strong pair of kid glores to protect the hands from the scratches and cuts which they are certain to receive if unprotected from the prickly leaves of Holly or from the binding wire. Although I recommend strong kid gloves, I do not mean them to be thick or in any way clumsy, as, if that were the case, it would be impossible to do any of the fine work-such as letters in single leaves-neatly. Having thus alluded to the different materials required, let me now direct attention to the manner in which particular designs are manufactured.

\section{Garlands.}

As has been stated, the best material for the foundation of these is strong hemp cord; a loop should be made on one end, and this is slipped orer a nail or hook, fastened for the purpose in a wooden table or in anything that will hold it firmly. Haring a supply of evergreens at hand, cut to the required lengths, bind them on to the cord with fine twine; one firm twist of twine will be enough to keep each bunch of evergreens in its place, and so work down the cord to whatever length may be required. A beginner will find it difficult to keep the garland even as it is being worked; but, if such be found to 
be the case, where it is too full, the picces can be thinned out with a pair of scissors. If it be desired to suspend a garland of large dimensions at any height, the following shrubs will be found the best adapted for its construction, riz.:-Arbutus, Euonymus (common), Holly, Iry, Laurel, Portugal Laurel, Spruce and Silver Firs, and Yew. For giring colour, of course, scarlet berries are indispensable, and first amongst these ranks the Holly; but as the berries of the Holly are not plentiful every season, it may be well to enumerate a few others which can be substituted. There is the Arbutus, its lovely berries looking in the distance like little clusters of Siberian Crabs; and the burst seed-pods of the Gladwin, which, of late, have taken such a prominent place in florists' windows. The latter can be purchased in town by the bunch for a very small sum, while those who live in such counties as Devon, Somerset, and Dorset can obtain as many as they require by simply cutting them in the hedgerows or on the cliffs, as the Gladwin is to be met with, growing plentifully in a wild state, in those counties. When the berries of this plant are emplojed, they must be worked in with the evergreens at equal distances, as the formation of the garland is procecded with; but the best way to arrange the Holly berries is to remove all the leares and cut off the stems, leaving that portion only which is corered with berrics; a pieco of fino binding wire can then be fastened round the stem and passed round the garland, and, where fastened, hid amongst the folinge. In this manner, all the berries can be added after the garland is made. Some introduce flowers made 
of colonred tissue paper, but I myself prefer colour being given with berries only. Small and lightlooking garlands for suspending from gas brackets, \&c., can be made on fine twine, in a similar manner to those before described; but, for this purpose, very small-leaved plants should be employed, snch as the Prickly Holly, variegated Box, \&e.

\section{Upright Wreaths or Beadings.}

These are made best on fine iron rods, and their manufactnre is very similar to that of garlands, save that the beadings are made on one face, and for binding them reel wire should be substituted for twine. For this style of decoration I like to see branchlets of the dark green Holly only employed, its rich glistening sombre leaves being relieved by large bunches of the brilliant berries fastened on with wire, as I have before described, at equal distances apart. Wreaths of rery pretty appearance can be made on strong wire for hall lamps, \&c., by taking a pices of wire and forming it into a circle of whatever size may be required; on this bind the evergreens with fine wire, using plenty of berries in their construction; blooms of Laurustinus also work in well for this purpose.

\section{Ornamental Devices.}

These should have their foundations of perforated zine, eut out into whatever design may be selected. The foundations of the thrce accompanying illustrations on this subject are supposed to be so formed, 
otherwise it would be impossible to make them as represented in the engravings. Two of the illustrations represent devices suitable for running round the top of the wall in sitting-rcoms, above the picture rods, and against the cornice, or round the door frame. The third or circular design is for hanging against any blank wall, or space between pictures, \&c. As will be seen in the first illustration, the half-circles are formed of a double row of single Holly leares; these are fastened on by means of a needle and strong dark green or black thread, the needle being passed up and down through the holes in the zinc. In sowing on the leares only one long stitch in each leaf is required, and the thread should pass along the mid-rib of the leaf, as in this manner it will not be observed. The branchlets of Yew are also sewn on, but more stitches must be employed on account of the length of the branchlets. The rariegated Iry is also sewn on, but each leaf of this plant requires three stitches to keep it open and firm in its position. Indeed, everything employed in the construction of the three accompanying illustrations is fastened in this manner sare the berries. The evergreens employed in the circular design ire as follows:-The circle is of Yew, the Holly leares which project are of the silver variety, the Iry leaves on the Yew circle are also almost perfectly white, a large bunch of Holly berries being fastened in the centre of each cluster. The star is formed of leares of Aucuba japonica, the centre being a tuft of white Iry leares with scarlet berries. All the Holly and Iry employed in the coustruction of the designs here 


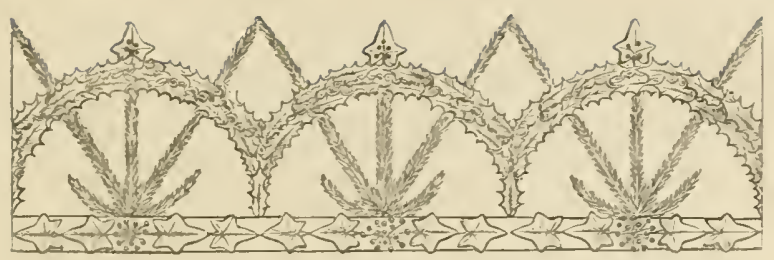

Ivy, Yew, Holly leaves and berries.

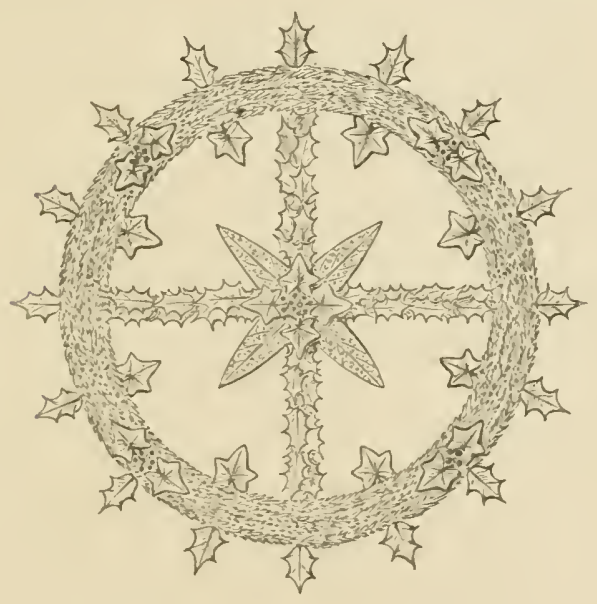

Yew, Ivy, Aucuba, Holly leaves and berries.

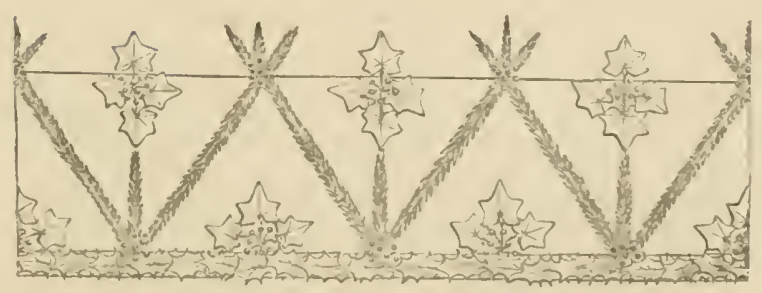

Ivy, Yew, Ifolly leaves aud berries. 

represented are of variegated kinds, as these are best adapted for placing in conjunction with Yew.

\section{Mottoes Formed of Letters Made of Evergreens.}

These are often employed amongst other styles of decoration. If of evergreens, the best leaves for this purpose are the Holly, as sharper outlines can be obtained with this than any other plant, the dark green or variegated kinds being selected according to taste. Whatever letters are required should be cut out in strong brown wrapping paper, and the leaves are then sewn on these foundations; letters of white, for placing on coloured grounds, can easily be formed by cutting out the letters in white paper instead of brown, brushing them over with liquid gum, and then covering them with grains of Rice. Narrow beadings of single leaves are best made on black tape wire, each leaf being sewn on as before described. Beadings of this description look most effective round door panels, \&c.

\section{Crosses.}

These should be made on foundations formed of flat laths, and if these are not obtainable, Hazel rods must suffice; unless a cross be of very large dimensions, small-leared plants should be employed as far as possible, and the lighter the colours are, if plenty of berries be used, the prettier will be the effect produced.

\section{Picture Frames and Texts.}

These can be made on laths in the same manner as crosses, but the Oxford shape, when finished, will 
he found by far the prettiest. If the evergreens selected be of dark colours they should be relieved at each corner by a tuft of light leares and scarlet berrics. Where it is not possible to fasten these frames orer those which encase the pictures, they may be suspended by a rery slight wire and allowed to hang immediately orer the ornamental or gilt ones.

All such decorations as I hare just described may hare their effect enhanced by being made to look as if frosted. This effect ean be produced in the following manner. The leares should be brushed over with gum in a liquid state, and then dusted with glass dust from the glass works, which can be obtained at a very small cost. A mirror draped with long tendrils and sprays of Iry only, sprinkled with fragments of ground glass, as I have described, has a most charming effect. Many use dried flower's, such as Everlastings, in these decorations, but I cannot say I admire thom; if a very short supply of berries be at hand, one is sometimes forced to use artificial ones, but if anything artificial can be dispensed with so much the better. Letters can be made in rustic forms with branchlets of Yew, which, if well frosted, are most eflective on a crimson or coloured gronulwork of anj description. As to the position of our old friend the Mistletoe, that must depend upon circumstances, and should be arranged as may be most convenient. $\Lambda$ few remarks may be made here on decorations composed of flowers. Across the back of the mantelpiece a small band of flowers may be formed on a lath, in the same manner 
as in the construction of crosses, save that in the place of branchlets of erergreens, Moss and flowers are substituted. The band or foundation being of green, alternate tufts of scarlet Geraniums and white Primulas look very effective; a few Fern fronds can also be introduced if desired. Should the flowers I have named be deemed too expensive, Primroses and Violets could be used. Orer the buffet a flat or one-sided bouquet could be placed-a large Arum bloom in the centre, and the rest composed of any scarlet and white, or pink and white, flowers that may be obtainable. I have now given descriptions of those kinds of Christmas decorations I can at the present moment remember as having seen made with an effective result. They are sufficiently nurnerous, at all events, to make any room look bright and suggestive of the season in honour of which it is decorated.

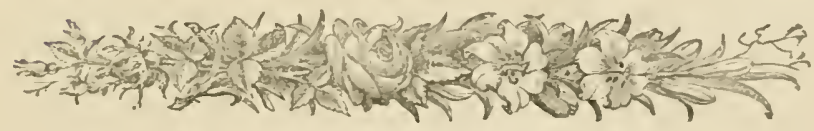





\title{
THE STUDENT'S FLORA OF THE BRITISH ISLANDS.
}

By J. D. HOOKER, C.B., F.R.S., President of the Royal Society.

Crown 8vo, 108. 6d.

"Certainly the fullest and most accurate manual of the kind that has yet appeared. . All botanists will recognise the many merits of this really important little manual."-Pall Mall Gazetie.

\section{PRIMER OF BOTANY.}

By J. D. HOOKER, C.B., F.R.S., \&c.

With Illustrations. 18mo, cloth, 1 s.

\section{LESSONS IN ELEMENTARY BOTANY.}

By D. OLIVER, F.R.S., F.L.S., Professor of Botany in University College, London.

With numerous Illustrations. New Edition. 18mo, 4s. $6 a$.

\section{FIRST BOOK OF INDIAN BOTANY.}

\author{
By Professor OLIVER, F.R.S., F.L.S.
}

With numerous Illustrations. Extra fcap. 8vo, 6s. 6d.

\section{HOLIDAYS ON HIGH LANDS;}

Or, RAMBLES AND INCIDENTS IN SEARCH OF ALPINE PLANTS.

By the Rev. HUGH MACMILLAN, LL.D., F.R.S.E.

Second Edition. Revised and Enlarged. Globe 8vo, 68.

"Mr. Macmillan's glowing pictures of Scandinavian nature are enongh to kindle in every tourist tho desire to take the same interesting high lands for the scene of his own autumn holidays."-Suturlay Review.

\section{FIRST FORMS OF VEGETATION.}

By the Rev. HUGH MACMILLAN, LL.D., F.R.S.E.

Being a New Edition, Revised and Enlarged, of "Foot-notes from the Page of Nature."

With numerous Illustrutions. Extra fcap. 800, 6s.

"Probably the best popular guile to the practical study of 3 rosses, Lichens, and Fungi over written."-Hanchester Examiner.

IF A CMILLAN \& CO., London. 
Recentiy published, in royal $8 v 0$, half-bound, price $318.6 d$,

$$
\text { WITH - 500 ILLUSTRATIONS, }
$$

\title{
A TEXT BOOK OF BOTANY, \\ MORPHOLOGICAL AND PHYSIOLOGICAL. \\ BY
}

\section{DR. JULIUS SACHS,}

Professor of Batany in the University of Würzburg.

Translated and Annotated by

A. W. BEN N E T T, M.A.,

Leeturer on Botany at St. Thomas's Hospital.

Assisted by

W. THISTLETON DYER, M.A.

\begin{abstract}
"The want of a good text-bnok of Botany, one that would give an accurate idea of the present state of botanical science, has long been felt by English students. We, therefore, heartily relcome the appearance of the English Iranslation of Sacbs' 'Lehrbnch der Botanik,' berause we feel certain that it will supply that nant sn long felt, aud be of the greatest Falue to both teachers and students."-Nature.
\end{abstract}

"The book before us rould form, and is likely to do so for some time to come, the best reference book for advanred stulent ; and wo cannct bring our remarks upon it to a close without expressing our thauks to all concerner for the protuction, in an Englisu dress, of so valuable a work of reference."-Gardeners' Chronicle.

Oxford: Printed at the CLAREXDON PRESS, and

Published by MACMULLAN \& CO., London, Publishers to the University. 
641901 


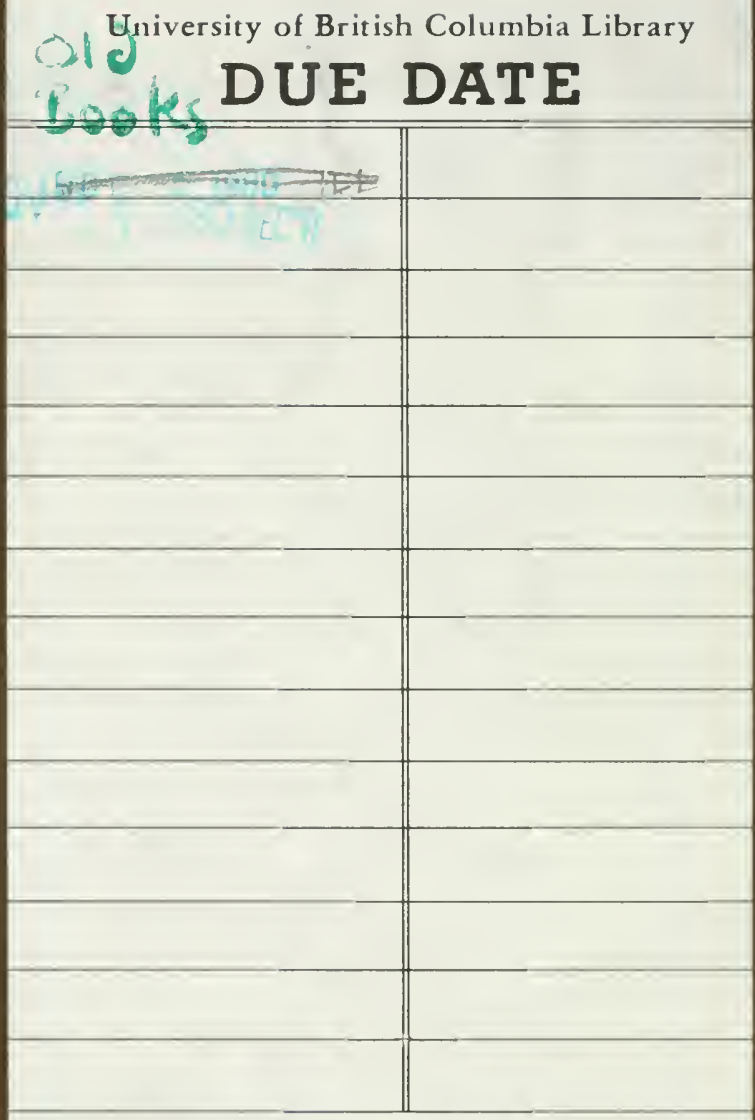




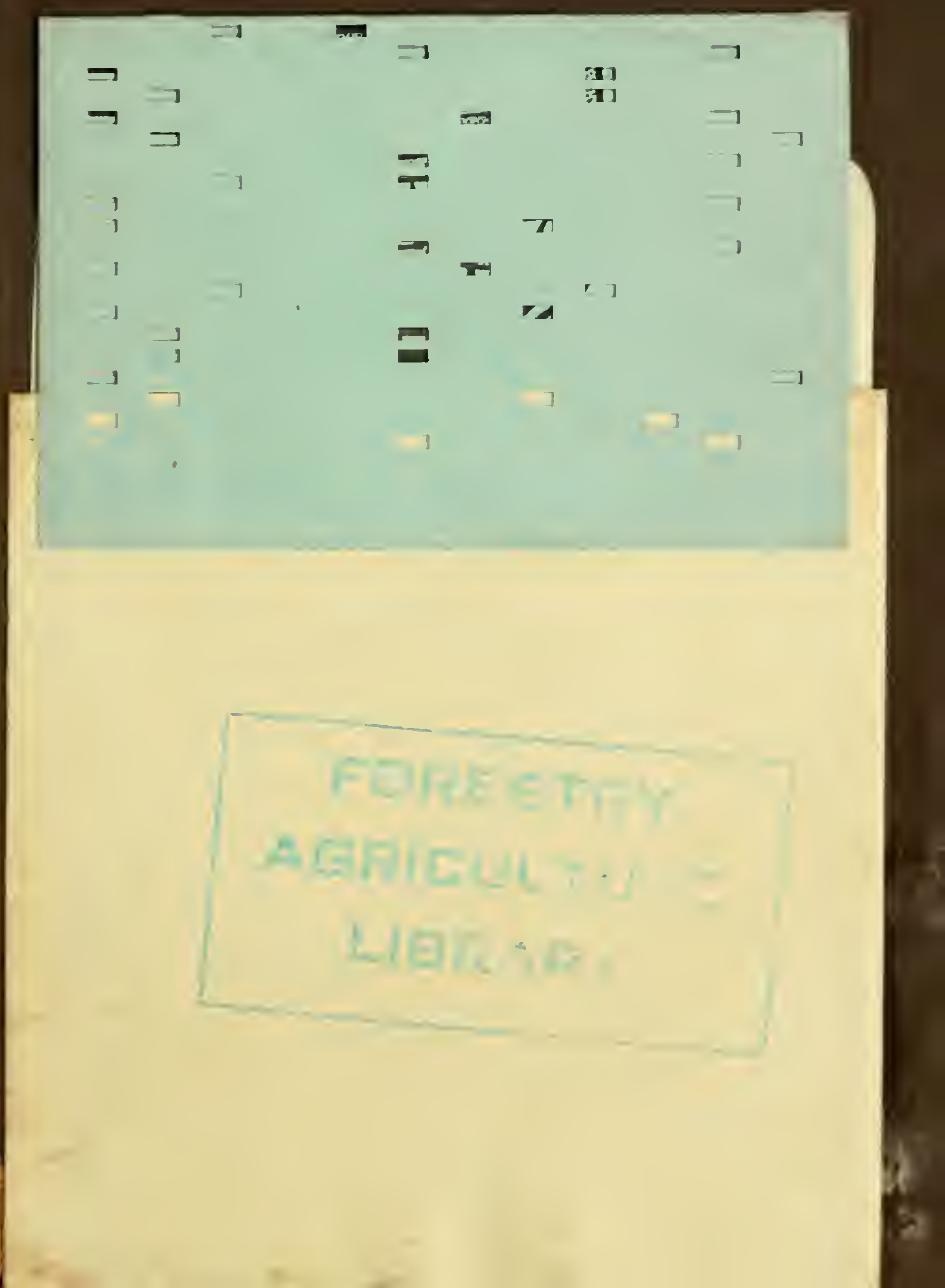




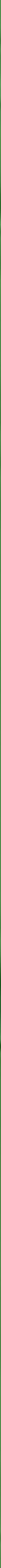

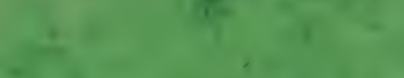

$$
\text { . }
$$

2

. 